\title{
Cascade Geothermal Drilling/Corehole N-3
}

\author{
Submitted to The Department of Energy \\ Mr. R. Jeffrey Hoyles \\ Dated July 19, 1988
}

Final report for Contract DE-FC07-85ID12613

By
Dr. Chandler A. Swanberg
Project Manager

\section{Geothermal Resources International, Inc. \\ 1825 S. Grant Street \\ Suite 900 \\ San Mateo, Ca. 94402}

\section{DISCLAIMER}

This report was prepared as an account of work sponsored by an agency of the United States Government. Neither the United States Government nor any agency thereof, nor any of their employees, makes any warranty, express or implied, or assumes any legal liability or responsibility for the accuracy, completeness, or usefulness of any information, apparatus, product, or process disclosed, or represents that its use would not infringe privately owned rights. Reference herein to any specific commercial product, process, or service by trade name, trademark, manufacturer, or otherwise does not necessarily constitute or imply its endorsement, recommendation, or favoring by the United. States Government or any agency thereof. The views and opinions of authors expressed berein do not necessarily state or reflect those of the United States Government or any agency thereof. 


\section{DISCLAIMER}

This report was prepared as an account of work sponsored by an agency of the United States Government. Neither the United States Government nor any agency Thereof, nor any of their employees, makes any warranty, express or implied, or assumes any legal liability or responsibility for the accuracy, completeness, or usefulness of any information, apparatus, product, or process disclosed, or represents that its use would not infringe privately owned rights. Reference herein to any specific commercial product, process, or service by trade name, trademark, manufacturer, or otherwise does not necessarily constitute or imply its endorsement, recommendation, or favoring by the United States Government or any agency thereof. The views and opinions of authors expressed herein do not necessarily state or reflect those of the United States Government or any agency thereof. 


\section{DISCLAIMER}

Portions of this document may be illegible in electronic image products. Images are produced from the best available original document. 
8135 Hydrothermal Systems

CORE HOLE DRILLING AND THE "RAIN CURTAIN" PHENOMENON AT NEWBERRY VOLCANO, OREGON

C. A. Swanberg, (Geothermal Resources Intermational Inc.,1825 S. Grant Strect, Suite 900, San Mateo, Ca 94402) W. C. Walkey, J. Combs

Two core holes have been completed on the flanis of Newberry Volcano, Orgeon. Core hole GEO N-1 has a beat flow of 180 mWm-2 reflecting subsurface temperature sufficient for commerical exploitation of geothermally generated electricity. GEO N-3, which has a heat flow of $86 \mathrm{mWm}-2$, is less encouraging. Considerable emphasis has been placed on the "rain curtain" effect with the hope that a detailed discussion of this phenomenon at two distinct localities will lesd to a better understanding of the physical processes in operation. Core hole GEO N-1 was cored to a depth of $1,387 \mathrm{~m}$ at a site located $9.3 \mathrm{~km}$ south of the center of the volcano. Core hole GEO N-3 was cored to a depth of $1,220 \mathrm{~m}$ at a site located $12.6 \mathrm{~km}$ north of the center of the volcano. Both core holes penetrated interbedded pyroclastic lava flows and lithic tuffs ranging in composition from basalt to rhyolite with basaltic andesite being the most common rock type. Potassium-argon age dates range up to $2 \mathrm{Ma}$. Difficult drilling conditions were encountered in both core holes at depths near the regional water table. Additionally, both core holes penetrate three distinct thermal regimes (isothermal (the rain curtain), transition, and conductive) each having its own unique features based on geophysical logs, fluid geochemistry, age dates, and rock alteration. Smectite alteration, which seems to control the results of surface geoelectrical studies, begins in the isothermal regime close to and perhaps associated with the regional water table. 
on the gamma ray $\log (N-1, N-3)$ and the electrical conductivity $\log (\mathrm{N}-1)$. (2) temperatures below surface amblent measured downhole with a maximum recording thermometer (MRT) during periodic pauses in drilling operations (N-1, $N-3)$, and (3) drilling fluids whose chemistry does not reflect an influx of geothermal fluids $(N-3)$. In contrast, the thermally conductive regime is characterized by (1) a high and variable response on the gamma ray $\log (N-1, N-3)$ and on the electrical conductivity $\log (N-1)$. (2) temperatures (MRT) measured downhole during pauses in drilling which are above ambient and which track in situ conditions $(N-1, N-3)$, and (3) drilling fluids whose chemistry clearly reveals a geothermal component $(N-3)$. The transition zone is characterized by major washouts in the caliper $\log (\mathrm{N}-1$, N-3), a major anomaly in the mercury content of the rocks (H-1), an extremely strong response on the gamma-ray $\log (N-1, N-3)$ and electrical conductivity $\log (N-1)$, and a major SP anomaly $(N-1)$. Smectite alteration, which seems to control the results of surface geoelectrical studies, begins in the isothermal regime close to and perhaps associated with the regional water table.

\section{TRIRODOCTIOX}

The Cascade Range, which consists of a serles of Quaternary and late Tertiary andesitic volcanoes that extend from northern California to southern British Columbia, is a geologle province with immense potential for the generation of electricity from geothermal resources. The geothermal potential for the cascades 
Province may well be thousands if not tens of thousands of megawatts [Bloomquist, et al., 1985]. Yet to date, there are no geothermal power plants operating in the Cascades Province, and none are planned. Furthermore, except for the obvious heat sources represented by the active volcanoes, very little is known about the potential geothermal resources in the cascades.

The geothermal literature is particularly sparse on such key parameters as the chemistry of geothermal fluids, the deep thermal structure of the geothermal systems, and the nature of reservoir host rocks in the Cascades. The Northwest Power Planning council [1986], has not even included geothermal energy in their long-range power forecasts, stating that "Because the information regarding the character and extent of the regional geothermal resource areas used to prepare the estimates of cost and availability is very preliminary, this resource (geothermal) cannot be considered as available for the resource portfollo of this power plan."

The paucity of geothermal data in the Cascades Province and the consequent reluctance of the utility companies to plan for future geothermal development can all be traced to the olngle phenomenon known as the rain curtain." Thls term refers to the zone of hydrologic disturbance where cool meteorlc water percolates downward and spreads laterally, therefore masking the surface expression of geothermal activity. The rain curtain can severely complicate, if not render useless, the standard geophysical and geochemical techniques for locating and 
evaluating geothermal reservoirs. For example, hot oprings are typically diluted or masked completely, temperature gradient holes may be isothermal to depths in excess of a kilometer, and surface geoelectrical studies must be designed to penetrate a kilometer or more of "noise" before geothermally useful data can be obtained. A case in point is Newberry Volcano, Oregon (Flgure 1). where the rain curtain ranges in thickness from less than 300 m within the caldera [Black, et al.. 1984] to about $1,000 \mathrm{~m}$ on the southern flank (Swanberg and Combs, 1986). The cool meteoric zone overlies a geothermal system that is at least $265^{\circ} \mathrm{C}$ at a depth of $900 \mathrm{~m}$ [Samel, 1981], yet supresses the surface manifestations of this system to the extent that only two small warm springs exist over the entire volcano. various geoelectric and geoelectro-magnetic studies including magnetotellurics (D. Stanley, U.S. Geological Survey, Denver, Colo.: personal communication, 1986), Schlumberger soundings [Bisdorf, 1985), and transient geoelectromagnetic soundings [Fitterman and Neev, 1985] have shown the presence of electrically conductive zones both inside and outside the caldera, but the lack of driling data has precluded a rigorous interpretation of these conductors [Fitterman and Neev, 1985, p. 409]. 
In recognition of this situation, the U.S. Department of Energy (DOE), Division of Geothermal and Eydropower Technologies (DGHT), initiated a Cascade Deep Thermal Gradient Drilling Program. The stated purpose of the program is to "support industry efforts in the Cascade Volcanic region" and the stated objectives are to "cost share with industry for the drilling of gradient holes which would penetrate the'rain curtain' and obtain deep thermal, Iithologic, and structural data." In exchange for the cost sharing, the industry participant would "release (the datal to the public for the benefit of the geothermal industry and the scientific community," [Cascade Newsletter, 1986 ].

To date, GEO Operator Corporation (GEOOC) has cored and completed five core holes at Newberry Volcano two of which were drilled under the DOE Cascades orilling Progran. The first costshared core hole, GEO N-1, was completed in the fall of 2985 to a depth of 1.387 m on GEO leaseholds on the south flank of the volcano. Data and core Erom the upper 1,219 are in the public domain (Cascade Newsletter, 1987). The second cost-shared core hole, GEO N-3, was completed In the summer of 1986 to a depth of $1.220 \mathrm{~m}$. Data and core from all of this core hole are in the public domain (Cascade Newsletter, 1987). In the following sections, the basic data from these two core holes are presented with some preliminary observations which pertain to the understanding of the phenomenon of the rain curtain and its physical characteristics. We hope, the data and observations will lead to an enhanced understanding of the rain curtain; to 
subsequent refinements in geothermal exploration techniques for use in the Cascade Province; and finally, to an Increased understanding of Cascade geothermal systems and their potential for economic exploitation.

\section{GEOLOGY OR NEKBERRY VOLCANO}

Newberry Volcano, covering roughly $1,300 \mathrm{~km}^{2}$ in central Oregon, is one of the largest volcanoes in the conterminous Onited states and is one of a series of Quaternary bimodal volcanoes located to the east of the main cascade Range trend (Figure 1). The volcano lies near the juncture of the cascade Range with the Brothers Fault zone, a northwest trending fracture system along which silicic volcanism and rhyolitic domes become progressively younger to the northwest (MacLeod, et al., 1975). Considerable research has been conducted at Newberry during the past several years (Sammel, 1981; MacLeod, et al.. 1981; MacLeod and Sammel, 1982; Macleod, et al., 1982; Ciancanell1, 1983; Priest, et al., 1983, 1987), which update the earller work of williams (2935) and Higgins (1973). Holes drilled within the caldera by the U.S. Geological Survey (USGS) and Sandia National Laboratorles attalned $265^{\circ} \mathrm{C}$ at 932 [Sammel, 1981) and greater than $160^{\circ} \mathrm{C}$ at $424 \mathrm{~m}$ [Black, et al., 1984], respectively. The geothermal potential of Newberry Volcano has been estimated at 740 MWe for 30 years by the uSGS [Muffler, 1979] and 1.551 Mare for 30 years by Bonneville Power Administration [Bloomquist, et al., 29851. 
volcano in order to determine whether there is radial symmetry of the heat source. Core hole GEO N-1 was drilled near the neck of a very young basalt flow, the surveyors flow whose age is probably comparable to the $5,835 \pm 195$ years B.P. date obtained for the near surface clnders at the drill site (Swanberg and Combs, 19861. The core hole is also located near the center of a major soil mercury anomaly [Badden, et al., 1982).

The average heat flow from GEO $\mathrm{N}-1$ is $180 \mathrm{mmm}^{-2}$ based on a least squares fit to temperature-depth data over the thermally. conductive regime between 1,164 and $1,219 \mathrm{~m}$ and twelve (12) measurements of thermal conductivity representing the same interval (Table 1). Heat flow values of this magnitude imply temperatures in excess of $200^{\circ} \mathrm{C}$ at depths less than $3 \mathrm{~km}$. Such temperatures are sufficiently high and accessible as to imply the possible commercial exploltation of geothermal resources for the generation of electriclty utilizing either the single or double flash power conversion technologies, provided of course, that suitable production zones can be encountered in deep geothermal we118.

\section{Geophys lcal Logging Prograx}

The physical condition of core hole GBO N-I caused deviation From a traditional geophysical logging progran. Specifically. the interval 378 to 549 m was known to be associated with caving and sloughing. In order to minimize the risk of loosing a logging tool and possibly the entire core hole, it was decided to forego 
the geophysical logs over this interval. Therefore, after drilling to total depth, the rods were pulled to a depth of about $550 \mathrm{~m}$, leaving the upper $550 \mathrm{~m}$ of the core hole, including the incompetent section, behind pipe. The remainder of the hole was open. The hole was then conditloned and a suite of logs were run from 550 m to total depth. After this first logging run, the rods were pulled out of the hole and the geophysical logs were run from the base of the surface casing at $143 \mathrm{~m}$ to the top of the incompetent section $378 \mathrm{~m}$. The logging program called for temperature, induction, gamma-ray, caliper, sonic, BHC acoustic fraclog, and density logs; however, the density log was terminated because the tool would not freely penetrate the section.

\section{Depth To Water Table}

The depth/elevation of the water table is an important parameter in regional hydrologic studies of geothermal systems and is also useful in interpreting the results of experiments conducted at the surface or within the core bole. Onfortunately, the water table at GEO N-I seems to be an eluslve phenomenon. None of the geophysical logs indicate an obvious perturbation that might represent the water table. It is possible that the water table lies in the interval 378 to 550 which never was logged. The driller routinely estimates and records the standing water level in the core hole and almost all such estimates fall within the unlogged interval, the most common estimate being 
about 490 m. This unlogged interval also represents the approximate depth at which smectite and other alteration products first occur within the subsurface section lBargar and Keith, 19861. These observations, coupled with the instability of the core hole (caving-sloughing), suggest a geologically plausible cause and effect relationship: l.e., geothermal fluids rising from depth spreading laterally near the water table and promoting hydrothermal alteration, which generally weakens the rocks. The closeness of the water table to physically incompetent rocks is noteworthy because it may allow difficult drilling conditions to be predicted, thus reducing the risks (drilling problems such as stuck rods and twist off) and costs.

\section{The Temperature $\log$}

The equilibrium temperature $\log$ is shown in Figure 3 and was taken ten (10) months after drilling. The data from all temperature logs over the interval 450 to 1,219 a are illustrated in Figure 4. At least three (3) distinct thermal regimes can easily be recognlzed on the logs (see flgure 3 or 4 ). The temperature $\log 1 s$ isothermal at mean alr temperature $\left(6^{\circ} \mathrm{C}\right)$ down at least to the water table at about 490 m and probably beyond. The interval $1,158 \mathrm{~m}$ to TD is a thermally conductive regime. Between the 
lsothermal and conductive regimes lies a third interval over which the temperatures increase very rapidly with depth (see Pigures 3 and 4 ).

The nature and extent of the uppermost isothermal section (the rain curtain) has been the subject of debate among several workers who have examined the temperature logs. There is no doubt that the rain curtain extends at least to the water table (about $490 \mathrm{~m}$ ), but there is a question as to whether the isothermal temperatures measured for several hundred meters below the water table indicate a rain curtain, or merely water percolating downward in the annulus between the completion tubing and the walls of the core hole.

One scenario has the rain curtain extending to an approximate depth of $1,005 \mathrm{~m}$., at which point the downward percolating groundwater exits the volcano along the highly permeable horizons depicted on the geophysical well logs (Figure 5). In this first model, the rain curtain is located in a sulte of volcanics whose geologlcal character (including porosity and permeabillty) is distinct from the sulte of rocks lying below. This model 18 favored by the fact that the volcanlc section does In fact change character at depths near the bottom of the isothermal section (Figure 5), and also by the fact that temperatures measured during pauses in drilling operations were never above ambient until depths of 500 meters below the water table.

A second scenario [Blackwell and steele, 1987) has the rain 
curtain extending to a depth of 350 to $400 \mathrm{~m}$, while the remaining isothermal interval is a consequence of intra-hole fluid flow. In this second model, the rain curtain would colncide with the region above the water table. This model is favored by its simplicity and by the observation that an extrapolation upwards of the deep temperatures intersect mean air temperature at a depth which is not incompatible with the water table.

A third (preferred) hybrid possibility would accommodate limited groundwater flow within the annulus over the interval 1,005 to $1,158 \mathrm{~m}$. The first or third model is favored on the assumption that the temperatures measured during drilling are diagnostic, if not highly accurate, thus precluding the second model, which associates the rain curtain with the water table. Also, the first and third models are more compatible with the Eluid geochemistry data from GEO $\mathrm{H}-3$ which are discussed below.

\section{The Hercury Log}

Core hole GEO N-I was sited on one of the najor soll mercury anomalies of Eadden, et al. [1982], as was the OSGS core hole NB-2, whlch was located near the center of the volcano, and which encountered temperatures of $265^{\circ} \mathrm{C}$ at 932 meters (Sammel, 1981 ). Because soll mercury surveys are routinely used as a surface manifestation of sub-surface geothermal conditions, it was decided to attempt a detalled mercury survey of the rocks penetrated by core hole GEO N-1 in the hopes of learning more about the migration of mercury from a geothermal reservoir to the 
surface. The sampling procedure was to randomly select several core fragments from each $3-m$ interval, pulverlze and sieve the aggregate to the same mesh as typlcally used in soll mercury surveys, and analyze the resulting powdered core sample for mercury content. The results of the survey are shown in Figures 5 and 6. The upper part of the core hole failed to yleld detectable levels of mercury so the sampling technique was modified to emphasize altered zones and fractures. This technique also failed to yield detectable mercury. However, once the hydrologically disturbed zone between 945 and 1,000 was entered, a major mercury anomaly was encountered. This anomaly has been verified by resampling and laboratory analysis by an independent laboratory. The mercury anomaly is shown in Figure 5 in relation to other core hole data sets and the correlation among the mercury anomaly, the rapid temperature buildup, and the "washouts" in the caliper log are quite obvious. clearly. geothermal fluids relatively enriched in mercury are migrating through this interval. But, the relationship between this mercury anomaly within the core hole and soll nercury anomaly at the surface remalns unclear. Hone of the other fracture or rubble zones in the core hole are enriched in mercury, and the Iow background levels of mercury throughout the core hole would seem to preclude the volcanic plle ltself as the source of the soil mercury anomaly. These data are consistent with the standard concept that soll mercury anomalles result from clay entrapment of mercury ascending along fractures from depth. Bowever, it is not possible to prove that the mercury anomaly at 
depth is the origin of the soll mercury anomaly observed at the surface.

Geophysical Logs: Electrical Conductivity

A generalized electrical conductivity log derived from the induction $\log$ for core hole GEO $\mathrm{N}-1$ is shown in Figure 5 . It was prepared by averaging the log over 30-meter intervals and plotting the resulting average at the midpoint of the 30 -meter section. Thus, any anomalous point in this $\log$ may be reflecting changes up to 15 meters on either side of the depth at which the point is plotted. The logic behind this type of presentation is the expectation that gross changes in the electrical properties of the volcanic pile might be detected from the ground surface using traditional geoelectric or geoelectromagnetic surveys. Examination of the generalized electrical conductivity log (Figure 5) shows the volcanic pile to be of generally constant conductivity down to a depth of $945 \mathrm{~m}$. This interval of uniform conductivity coincides very well with the rain curtain as defined by the flve temperature data sets (Figure 4). The conductivity log shows no obvious perturbations at the water table (490 m), at the onset of smectite alteration (Figure 5, Column 2), or at the depths at which smectite alteration becomes ublquitous (Figure 5 , Column 2). Below $945 \mathrm{~m}$, the volcanic pile becomes significantiy more conduct lve and more varlable in its electrical conductivity. The increased electrical conductivity may result as a direct consequence of higher temperature or from the effects of increasing rock alteration (Figure 5). In elther case, the 
increased conductivity represents a marked change in the physical properties of the volcanic pile which is related to geothermal activity and which at least in theory. should be detectable from the surface. Fitterman and Neev $(1985)$ have published the results of a one-dimensional geoelectrical model based on a transient geoelectromagnetic sounding (TS) located at the GEO N-1 site. This model is reproduced in Figure 5, Column 1 as "TS Resist Section $\Omega-\mu_{0}$ " Unfortunately, the model appears to reflect smectite alteration and not the geothermal system. A similar conclusion has been published by Wright and Nelson [19861, also based on analyses of data from core hole GEO N-1.

\section{Geophysical Logs: Gamma Ray}

A generalized gama ray log for core hole GEO $N-1$ is presented in Figure 5. It was prepared in a manner analogous to the electrical conductivity log, l.e., averaged over 30-meter sections and plotted at the midpoint. The generalized gamma ray $\log$ is Ealrly uniform from the surface to a depth of $945 \mathrm{~m}$, below which the rocks become significantly more potassic (see stratigraphle coluran, Figure 6 ).

It is interesting to note that the gamma ray and electrical conductivity logs are inversely correlated throughout the nonisothermal section of the core hole (1.e., below $945 \mathrm{~m}$ ), but not in the isothermal section (1.e., 0-945 m). A thermal origin for this inverse correlation is suggested and probably reflects the manner in which laterally migrating geothermal fluids promote rock alteration. Apparently, the more maflc glass-rich basalts 
are more prone to undergo alteration to highly conductive clay minerals such as smectite than are the more potassic rocks which show the strong gamma ray signature (from $\mathrm{k}^{40}$ ). The lack of the inverse correlation throughout the isothermal section would, therefore, reflect a lack of migrating geothermal fluids (see Figures 3, 4), a general lack of felsic volcanics (see Figure 6), or a combination of both.

\section{Geophysical Logs: Caliper}

The core hole diameter over the interval 550 to $1,045 \mathrm{~m}$ as depicted by the caliper $\log$ is presented in Figure 5 . The three lower washouts and their association with the rapid temperature increase and other anomalous features of the core hole have already been discussed. The four washouts further up the core hole do not appear to reflect migration of geothermal fluid (i.e.. they are in the rain curtain).

\section{Geophysical Logs: SP}

The SP $\log$ (Figure 5) undergoes a drop of $70 \mathrm{mv}$ over the interval from about 1,000 to $1,020 \mathrm{~m}$. This feature probably reflects fluld movement, and 18 the only such feature on the SP $\log$. 


\section{Rock Alteration}

Bargar and Keith [1986) have studied the alteration mineralogy of core hole GEO $\mathrm{N}-1$. A generalized depiction of smectite alteration, taken directly from Bargar and Keith [1986), Is shown in Figure 5. The relationships among alteration mineralogy, the electrical conductivity $\log$, and surface geoelectromagnetic studies are discussed elsewhere in this report.

\section{Potassium Argon (K-Ar) Age Dates}

$K-A r$ age dates representing surface sampies collected from around Newberry volcano are presented in Figure 2 and typically are less than $2 \mathrm{Ma}$ although ages as old as 5 to $7 \mathrm{Ma}$ are reported for the outer flanks of the volcano. Age dates representing samples taken from core hole GEO $\mathrm{H}-1$ increase systematically with increasing depth from values of 27,000 and 29,000 years B.P. at 481 and 491 meters, respectively, to $2.63 \mathrm{Ha}$ at 1,081 meters (Figure 7. Table 2). In addition, in an earlier report, Swanberg and Combs (2987), reported the results of a single $c^{14}$ age date based upon chaccoal discovered while digging the wud sumps. Thls date of $5835 \pm 195$ years B.P. establishes the age of the basaltic cinders at the surface near the core hole.

Whenever age dates are determined in a geothermal environment, the possibility always exists of nonrepresentative ages due to argon diffusion and subsequent resetting of the $R$-Ar clock. Perhaps the best testament to the reliability of the age dates presented in Table 2 and rigure 7 is the fact that they are 
geologlcally reasonable. The dates are generally compatible with those determined from surface samples throughout the volcano. The dates increase systematically with depth throughout the core hole and there is no radical departure from this trend upon encountering the zone of ubiquitous smectite alteration near 700 meters (Figure 5) or encountering the zone of rapid temperature buildup near 1,000 meters.

\section{Chemistry of Formation Fluids}

During drilling operations, fluid samples were episodically selected for chemical analysis. Although such samples would be severely contaminated with drilling mud, it was felt that various geothermal constituents might be detectable above the background and if so, would serve to Indicate any environmental problems that might be encountered during eventual production. The results of silica analyses as a function of depth are presented in Figure 8. Representative samples of the drilling fluid are also shown. Analyses of other chemical constituents are even less revealing than silica and are not reported here.

\section{The Rain Curtain as a Lithologic Discontinuity}

The coincidence that the generalized gamm ray and electrical conductivity logs both change character at a depth $(945 \mathrm{~m}$, Figure 5) whlch is compatible with the rain curtain as defined by the five temperature data sets (Figure 4 ) suggests the possibility that the rain curtain may represent a lithologic 
discontinuity. An intriguing (but speculative) extension of this logic is to associate such a discontinulty with the transition between pre- and post-Newberry strata. The pre-Newberry strata are generally more felsic than the Newberry pile (Clancanelli personal communication, 1987), so that the pre/post Newberry transition might well produce a generalized garma ray signature similar to that shown in Figure 5. Macleod and Sherrod Ithis issue] confine the Newberry section to those normally polarized strata younger than $0.73 \mathrm{Ma}$. The $\mathrm{K}$-Ar age dates shown in Figure 7 are compatible with a pre/post Newberry transition at $945 \mathrm{~m}$. In fact, using selective license with the error bars on the $R-A r$ age dates (Table 2), indicates that all age dates shallower than $945 \mathrm{~m}$ are $0.737 \mathrm{Ha}$ or less, while all age dates deeper than $945 \mathrm{~m}$ are older than $0.73 \mathrm{Ma}$. At present, however, the data do not totally support the postulation of a depth or even the existance of a pre/post Newberry discontinuity. Any $x-A r$ age date for extremely young, potassium poor rocks located in a geothermal regime are subject to question and although the age dates presented in rable 2 and figure 7 are considered reliable, this issue should be tabled until the paleomagnetic studies have been completed and the $K-A r$ age dates have been verifled.

CORE HOLE N-3

Core hole GEO $\mathrm{N}-3$ was drilled at a surface elevation of $1.753 \mathrm{~m}$ on the north flank of the volcano at a distance of 12.6 $\mathrm{km}$ from the center of the volcano (see Figure 2). Of all of the Newberry core holes, GBO N-3 is the most distant from the center 
of the volcano. Heat flow from GEO N-3 is $86 \mathrm{mWm}^{-2}$ based on a least squares fit to the temperature-depth data over the thermally conductive region between 1,170 and 1,220 meters and nine (9) measurements of thermal conductivity representing the same interval (Table 1). This value is typlcal of heat flow values found throughout the non-geothermal areas of the cascade Range [Blackwell and Steele, 1987] and, therefore, does not indicate the presence of an exploitable geothermal resource. This core hole, located $12.6 \mathrm{~km}$ from the center of the volcano, apparently constrains the radial extent of the major geothermal system associated with the core of Newberry Volcano. If geothermal resources are to be located at such large distances from the center of the volcano, they must be associated with heat sources which are separate from the main volcanic heat source.

\section{Geophysical Logging Progran}

As in core hole GEO $\mathrm{N}-1$, the integrity of core hole GEO $\mathrm{N}-3$ forced modifications to the geophysical logging program. Speciflcally, at a depth of about 520 m the rods became stuck in the core hole and were cemented in place, causing a reduction in hole size. To compound the problem, the induction tools and gamma-ray tools, required to penetrate the smaller diameter hole all failed. The gama-ray $\log$ was recovered from the surface to total depth, since this $\log$ could be run through the completion tubing, but the Induction $\log$ was lost. The temperature $\log$ and the neutron density log were also run from surface to total depth but the caliper $\log$ and BBC acoustic fraclog could only be run 
from 520 m to total depth. The casing schematic for core hole, GEO N-3 is shown in Figure 9.

\section{Depth To Mater Table}

The depth to the regional water table is just as elusive as in GEO $\mathrm{N}-1$. The standing water level in the core hole as estimated by the drillers ranges from about 455 to $565 \mathrm{~m}$ with a modal value of $525 \mathrm{~m}$. Thus, the water table may well lie close to, and perhaps exactly at, the depth at which the drilling problems were encountered which forced the cementing of the rods in place. Therefore, the failure of the geophysical logs to clearly reveal the water table may well result from the complicating effects of the metal rods and the cement.

\section{The Temperature Log}

The final temperature $\log$ for core hole GEO $N-3$ is shown in Figure 10 and compared with other data sets in Figure 9. A composite of all temperature logs measured in this core hole is presented in Figure 11. At first glance, the final temperature log appears to differ slgnificantly from the corresponding log for core hole GEO N-1 (Figure 3). Closer examination, however, reveals that the two logs contain the same basic elements. Speciflcally, like GEO N-I, core hole GEO N-3 is isothermal to the water table and probably beyond, it has a thermally conductive zone near the bottom, and the isothermal and conductive zones are separated by a transition region exhibiting consider- 
able hydrologic disturbance.

The interval between the upper isothermal and lower conductive sections of core hole GEO $N-3$ is a complicated reglon because it represents two separate and overlapping patterns of groundwater circulation, one of which was induced by drilling operations. Several obvious features of the temperature log are the rapid buildup of temperature at about 580 to $610 \mathrm{~m}$, the smaller temperature buildup at about $1,160 \mathrm{~m}$, and the interval between them which is very nearly isothermal at $52^{\circ} \mathrm{C}$. These observations are the result of artesian water ascending the annulus of the core hole. Geothermal fluids under artesian pressure appear to enter the core hole at a depth of about $1,160 \mathrm{~m}$. This same depth is charactered by a significant washout as observed on the caliper $\log$ (Figure 9 ) and also by a thermal pulse as detected by the maximum recording thermometers (MRTs) which were run into the core hole during pauses in the drilling operations (Figure 11). The geothermal fluids appear to exit the core hole annulus at a depth of about 575 to $585 \mathrm{~m}$. This zone is a major washout area as shown by the caliper $\log$ (Pigure 9). It is significant that the ascending geothermal fluids seem to ignore the numerous washouts throughout the core hole interval 610 to $1,100 \mathrm{~m}$ (Figure 9) and choose instead to exit the core hole annulus at a washout located at or near the regional water table estimated at about 455 to $564 \mathrm{~m}$. If a man-Induced vertlcal conduit such as a core hole will cause artesian fluids to rise and spread laterally near the water table, it might be expected that a natural conduit such as a vertical fracture might also 
cause the same phenomenon. If so, geothermal fluids migrating laterally near the water table are likely to promote hydrothermal alteration, reduce the mechanical strength of the rocks, and help explain why there seem to be difficult drilling conditions coincident with the water table.

The remaining unexplained feature of the GBO $\mathrm{N}-3$ temperature $\log$ is the nature of the thermal regime which existed before the artesian breakthrough. The germane data are the temperatures taken during drilling by maximum recording thermometers (MRTs. Figures 9 and 11 ). As was the case for GEO $N-1$, these temperatures showed no tendency to increase near the water table and in fact, readings did not exceed ambient temperatures until a depth of about $935 \mathrm{~m}$. On this basis, it is suggested that the rain curtain extends to an approximate depth of 915 to $975 \mathrm{~m}$ at which point the section becomes significantly more potassic as Indicated by the gamma ray and 1ithologic logs (Figures 9 and 12). Eaving the rain curtain extend to a signficant depth below the water table is supported by the close association between washouts as deplcted by the caliper $\log$ and small temperature anomalles measured by the MRTs during drilling operations. Careful Inspection of Figure 9 shows that below $915 \mathrm{~m}$, the MRT readings taken at or near the washouts are silghtly but consistently elevated relative to the remaining MRT values: as if thermal fluids were moving through these horlzons. Above 915 no such correlation exists. If the washouts above 915 in represent horizons which permit lateral flow of groundwater, it is not thermal fluid that is migrating through these horzions but rather 
cold, descending groundwater, l.e., the raln curtain. As a final comment for those researchers who prefer to assoclate the rain curtain with the region above the water table, it can be noted that an upward extrapolation of temperature from the thermally conductive region, intersects the mean annual alr temperature at a depth which is not incompatible with the water table.

\section{Ages Dates}

The seven $K-A r$ age dates from core hole GEO N-3, range from 0.1 to $1.5 \mathrm{Ma}$ and are presented in Figure 13 and Table 2 . These dates are similar to those measured in core hole GEO N-1 (Figure 7) and throughout the volcano (Figure 2). There is also a tendency for the age dates to increase with depth although the date of $1.5 \mathrm{Ma}$ at $324 \mathrm{~m}$ is contrary to this trend.

\section{Chemistry of Formation Fluids}

During the drilling operations for core hole GBO N-3, fluld samples were systematically collected from the core hole for routine chemical analyses. As was the case for GEO N-1, these samples were not collected to provide rellable geochemical data of formation fluids, but rather to try to detect the presence of geothermal flulds and any associated chemlcal species that may require special treatment during eventual production. The results of sllica concentration, a typical indicator of geothermal fluid, is shown as a function of depth in Figure 14. As shown in Figure 14, the bottom four (4) samples, which were 
collected from depths below $1,050 \mathrm{~m}$, are greatly enriched in silica relative to samples taken at other depths and this enrichment reflects the strong presence of geothermal fluids near the bottom of the core hole. Vertical zonation of the silica content of fluids sampled from GEO $\mathrm{N}-3$ is an interesting feature of the core hole that may relate directly to the depth of the rain curtain. To examine the phenomenon further, a composite of all anomalous chemical constituents was prepared and their distribution with depth was plotted in histogram form (Figure 15). Also shown in Figure 15 is a histogram of sample depth and a comparison of the two histograms should reveal the depths at which the anomalous chemical constituents are located. As can be seen in Figure 15, the anomalous constituents are found primarily below the arbitrary depth of $915 \mathrm{~m}$ and reflect the presence of geothermal fluids below this depth. Above $915 \mathrm{~m}$, nearly all samples collected are depleated in almost every chemical constituent analyzed and these samples are thought to represent the cold descending groundwater of the rain curtain. A comparison of the data in Figure 15 with that in Figures 9 and 11 shows the anticlpated result that the depths at which the chemically anomalous (geothermal) flulds were sampled are preclsely the same depths at whlch the highest temperatures were recorded during 
drilling operations. This almost trivial observation would probably not be worth reporting were it not for the important role played by the rain curtain in the exploration for and evaluation of geothermal resources.

\section{SUMMARY}

In the preceding sections, the data and some observations for two core holes on the flanks of Newberry Volcano, Oregon have been presented. Particular emphasis has been placed on the rain curtain with the purpose that a detailed discussion of this phenomenon at two discrete localities will lead to a better understanding of the physical processes in operation. It is further expected that the data will spark scientific debate and additional research on the rain curtain phenomenon, with emphasis directed towards surface geophysical techniques that can "see through" the rain curtain and provide valuable exploration information on the underlying geothermal reservolrs. Onfortunately, most geoelectric and geoelectromagnetic surveys to date have been strongly affected by smectite alteration which prevalls at depths that are shallower than the geothermal reservolr (Figure 5; see also Fitterman and Reev, 1985; Wright and Nellson, 1986) Wright and Nellson [1986) have noted that -delineation of the high temperature (geothermal) Bystem by electrical surveys may be difflcult or impossible because of effects from altered rocks." Whlle the problen is formldable, sufficient documentation has been provided that the rain curtain and the underlying geothermal systems are sufficientiy different 
in their physical characterlstics to justify continued search for a surface geophysical technique or a combination of techniques which will detect and provide information on geothermal systems, in spite of the complicating effects of the rain curtain and the smectite alteration. The goal is certainly worthwhile, since mile-deep core holes are rather expensive for reconnaissance exploration. 
ACKANOWLEDGEMENTS

We thank the management of Geothermal Resources International, Inc. (GEO), and its wholly owned subsidiary, GEO Operator Corporation (GBOOC), for financial support of, and permission to publish, thls work. We also thank Bruce sibbett (University of Otah Research Institute) for his outstanding job as technical lialson between GEOOC and the O.S. DOE, M. Johnson, H. J. Dansart, $M$. C. Bagood and $M$. Woodruff (GEOOC), for providing the core descriptions, and acknowledge the professional services of Tonto Drilling Services, Vancouver, Canada (drilling). Dresser-Atlas, Bouston, Tex. (geophysical logging), and Geotech Data, Poway, Calif. (temperature logging and thermal conductivity measurements). The figures were prepared by H. Maloney and the manuscript typed by $Y$. Stallings and $S$. Ballin of GEO. S. Prestwich and R. Ring acted as DOE technical and administrative monitors, respectively. The project was funded by D.S. DOE cooperative agreements DE-FC07-85ID12612 and DE-FC0785ID12613 (498) and GEO corporate funds (528). 
REPEREACES

Bacon, C. R.. Eruptive history of Mount Mazama and Crater Lake Caldera, Cascade Range, U.S.A., J. Volcanol. Geotherm. Res.. $18,57,1983$.

Bargar, R. E., and T. E.C. Reith. Hydrothermal mineralization in GEO N-l drill hole, Newberry volcano, Oregon, 0.S. Geol. Surv., Open File Rpt., 86-440, 12 pp., 1986.

Bisdorf, R. J.. Schlumberger sounding results over the Newberry Volcano area, Oregon, Geotherm. Resour. Counc1l Trans., 9, $389,1985$.

Black, G. L., G. R. Priest, and N. M. Woller, Temperature data and drilling history of the Sandia National Laboratories well at Newberry Caldera, Oreg. Geol., 46, 7, 1984.

Blackwe1l, D. D., and J. L. Steele, Geothermal data from deep holes in the oregon Cascade Range, Geotherm. Resour. Council Trans, in press, 1987.

Bloomquist, R. G., G. L. Black, D. S. Parker, A. Sifford, S. J. simpson, and L. $v$. Street, Evaluation and ranking of geothermal resources for electrical generation or electrical offset in Idaho, Montana, Oregon, and Nashington, Rep. DOE/BP-13609-1, 504 Pp., O.S. Department of Energy, Washington, D.C.. 1985.

Cascade Newsletter, No. 2, Earth Sci. Lab./Oniv. otah Res. Inst.. Salt Lake City, February $7,1986$.

Cascade Newsletter, No. 3, Earth Scl. Lab./Onlv. Otah Res. Inst.. salt Lake City. February $6,1987$. 
Ciancanel11, E. v., Geology of Newberxy Volcano, Oregon, Geotherm. Resour. Council Trans.. 7, 129, 1983.

Fiebelkorn, R. G., G. W. Walker, N. S. MacLeod, E. B. Mackee, and J. G. Smith, Index to $K$-Ar age determinations for the state of Oregon, U.S. Geol. Survey, Open File Rpt., 82-546, 39 pp.. 1982.

Fitterman, D. V., and D. R. Neev, Transient sounding Investigation of Newberry Volcano, Oregon, Geotherm. Resour. Council Trans., 9, 407, 1985.

Friedman, I., Eydration dating of volcanism at Newberry Crater, Oregon, J. Res. U.S. Geol. Surv., 5, 337, 1977.

Eadden, M. M., G. R. Priest, and N. M. Holler, Preliminary soilmercury survey of Newberry Volcano, Deschutes County, Oregon, Ore. Dept. Geol. and Min. Ind., Bonneville Power Administration Cooperative Agreement No. DE-AC79-82BP36734, 1982.

Biggins, M. W.. Petrology of Newberry Volcano, central Oregon, Geol. Soc. Am. Bul1., 84, 455, 1973.

Macheod, N. S., and E. A. Sammel, Newberry Volcano, Oregon: A Cascade Range geothermal prospect, Oreg. Geol., 44, 123, 1982.

MacLeod, H. S., and D. R. Sherrod, Geologic Evidence for a Magma Chamber Beneath Newberry Volcano, Oregon, J. Geophys. Res.. This issue.

MacLeod, N. S., D. R. Sherrod, L. A. Chitwood, and E. E. McRee, Newberry Volcano, Oregon, U.S. Geol. Surv. Circ, 838, 85, 1981. 
Macleod, N. S., D. R. Sherrod, and L. A. Chitwood, Geologlc map of Newberry Volcano, Deschutes, Klamath, and Lake Countles, Oregon, U.S. Geol. Surv. Open File Rep. 82-847, 1982.

Macleod, N. S., G. W. Walker, and E. B. McKee, Geothermal significance of eastward increase in age of upper Cenozolc rhyolite domes in southeastern Oregon, in Second Onited Natlons Symposium on the Development and Uses of Geothermal Resources, $\underline{1}, 465,1975$.

Muffler, L. J. P. (Ed.), Assessment of geothermal resources of the United States--1978, U.S. Geol. Surv. Circ. 790, 163 pp. 1979.

Northwest Power Planning Council, Northwest Conservation and Electric Power Plan, vol. 2, 271 pp.. Portland, Oreg., 1986.

Pierson, F. J., Jr., E. M. Davis, and M. A. Tanners, University of Texas radiocarbon dates 4, Radiocarbon. 8, 453, 1966.

Priest, G. R., B. F. Vogt, and G. L. Black, Survey of potential geothermal exploration sites at Newberry Volcano, Deschutes County, Oregon, Open File Rep., 0-83-3, 174 pp., Oreg. Dept. of Geol. and Min. Ind., Portland, 1983.

Prlest, G. R., N. H. Holler, and D. D. Blackwell, Geothermal exploration In Oregon, 1986, Oregon Geol., 49, 67, 1987.

Sammel, E. A., Results of test driling at Hewberry Volcano, Oregon, Geotherm. Resour. Council Bull., 10(11), 7, 1981.

Swanberg, C. A., and J. Combs, Geothermal drilling in the Cascade Range: Preliminary results from a 1387-m core hole, Newberry Volcano, Oregon, EOS, 67, 578, 1986. 
Willlams, B., Newberry volcano of central Oregon, Geol. Soc. An. Bul1., 46, 253, 1935.

Wright, P. M., and D. L. Neilson, Electrical resistivity anomalies at Newberry Volcano, Oregon; comparison with alteration mineralogy in GEO core hole $\mathbf{N - 1}$, Geothern. Resour. Council Trans., 10, 247, 1986. 


\section{TABLE 1}

BEAT FLOW - NEWBERRY VOLCANO, ORBCOY

\begin{tabular}{|c|c|c|c|c|}
\hline $\begin{array}{c}\text { Depth Range } \\
\text { (meters) }\end{array}$ & $\begin{array}{l}\text { Gradient } \\
\left({ }^{\circ} \mathrm{C} / \mathrm{km}\right)\end{array}$ & $\begin{array}{l}\text { Thermal } \\
\text { Conductlvity } \\
\left(\mathrm{wm}^{-1} \mathrm{~K}^{-1}\right)\end{array}$ & $\begin{array}{l}\text { Number of } \\
\text { Samples }\end{array}$ & $\begin{array}{l}\text { Beat Flow } \\
\left(\mathrm{mWm}^{-2}\right)\end{array}$ \\
\hline & & GEO $n-1$ & & \\
\hline $1,164-1,177$ & 122.7 & $1.76 \pm 0.40$ & 5 & 216 \\
\hline $1,180-1,192$ & 86.7 & 2.01 & 1 & 174 \\
\hline $1,195-1,219$ & 74.9 & $2.00 \pm 0.08$ & $\begin{array}{c}6 \\
\text { AVERAGE }\end{array}$ & $\begin{aligned} & \frac{150}{180}\end{aligned}$ \\
\hline & & GEO $\mathrm{N}-3$ & & \\
\hline $1,272-1,220$ & 54.3 & $1.59 \pm 0.14$ & 9 & 86 \\
\hline
\end{tabular}




\section{L-AC AGE DATES - NEWBERRY VOLCAFO, OREGOR}

\begin{tabular}{|c|c|c|}
\hline $\begin{array}{c}\text { Depth } \\
\text { (neter } 8)\end{array}$ & $\begin{array}{l}\text { Age } \\
\text { (Ma) }\end{array}$ & Description \\
\hline
\end{tabular}

fee $T$

$$
\begin{array}{ll}
1213 & 370 \\
1578 & 481 \\
1610 & 491 \\
2299 & 701 \\
2375 & 724 \\
2926 & 892 \\
2995 & 913 \\
3238 & 987 \\
3261994
\end{array}
$$

3.5461 .081
$0.306 \pm 0.075$

$0.027 \pm 0.009$

$0.029 \pm 0.081$

$0.090 \pm 0.026$

$0.847 \pm 0.110$

$0.768 \pm 0.147$

$0.746 \pm 0.110$

$0.943 \pm 0.053$

$0.997 \pm 0.050$

$1.630 \pm 0.23$

GEO R-1

Basaltic andesite

Basaltic andesite

Basaltic andesite

Basaltic intrusive

Basaltic andesite

Basalt

Basalt -

Andesite

Andes ite

Basaltic andesite
GBO $\mathbb{8 - 3}$

Phyrlc basalt

Phyrlc basaltic andesite

LIthic tufe

Basalt

Rhyodacitlc flow

Rhyodacitic flow

Basalt 


\section{PIGORB CAPTIONS}

FIGURE 1

FIGURE 2

PIGURE 3

FIGURE 4
Index map showing the location of Newberry Volcano in relation to the Oregon Cascades (stippled area).

Potassium Argon age dates (Ma) for surface samples at Newberry Volcano, Oregon. Data from Flebelkorn, et al. [1982] are plotted as age dates with the plot point representing the decimal point. Two GBO determinations are presented with errors indicated. The location of the Newberxy Flank Federal Geothermal Unit (area between the two boundarles), The Newberry known Geothermal Resource Area (KGRA inside the inner boundary), and the location of the two small lakes inside the crater are also shown.

Equilibrium temperature $\log$ for GBO N-1. Original data were collected $(9 / 25 / 86)$ by D. D. Blackwell and $R$. E. Spafford and were measured at 2-m intervals with a precision of $0.01{ }^{\circ} \mathrm{C}$. Data plotted at 10-m intervals.

Sumary of all temperature data below 500 a for GBO $\mathrm{N}-1$. Plotted points labeled " 1 " represent maximua recording thermometers (MRTs) which were allowed to sit on bottom for roughly 10 minutes without circulation. Logs 2 through 4 were obtalned by Geotech Data and represent discrete measurements at 3-a interval with a precision of $0.01^{\circ} \mathrm{C}$. Log 5 is the same as that presented in Figure 3. 
FIGURE 5 Comparison of GEO N-1 logs. From left to right: (1) the one dimensional geoelectric section determined from the surface measurements of Fitterman and Neev [1985] using transient geoelectromagnetic soundings (IS), (2) smectite alteration from Bargar and Keith [1986], (3) generalized electrical conductivity (see text for discussion), (4) generallzed gamma ray log (see text for discussion). (5) the location of the SP anomaly, (6) mercury $\log$ (see Figure 6 for detail), (7) location of washouts below $500 \mathrm{~m}$ as determined by the caliper log, (8) the bottom part of the temperature $\log$ shown in Figure 3 , and (9) the core hole completion. Note the unlogged section (conductivity $\log$ ) which reflects the depth interval of difficult drilling conditions and also the relationship between the zone of rapid temperature bulldup and anomalies in the other geophysical logs.

FIGURE 6 Generalized litholgic log and detalled rock mercury analyses for GEO $\mathrm{N}-1$. The detection thresholds for the Cascadla and Bondar-Clegg analyses are 1 and 5 ppb, respectively.

FIGURE 7 Potassium-argon age dates from GEO $N-1$. Note the agreement with the surface data shown in Figure 2.

FIGURE 8 SIIlCa content of fluids recovered from GEO N-1. Surface samples depicted as open symbols whlle downhole samples are shaded symbols. Note that all downhole samples are contaminated with drilling fiuld. 
FIGURE 9 Comparison of the temperature data from GEO $\mathrm{N-3}$ with the generalized gamma ray $\log$ and the washouts as depicted by the caliper log. Note: (1) the relation between the large washout in the callper $\log$ and the Intermediate drill string (drill rods cemented in place) reflecting the difflcult drilling conditions, (2) the anomalous temperatures measured during drilling (triangles) and the washouts at depths below $915 \mathrm{~m}$, and (3) the washouts which allow the artesian fluids to enter and exit the annulus of the core hole. The detailed temperature $\log$ is reproduced in Figure 10. Core hole completion presented on the far right.

FIGURE 10 Detailed equilibrium temperature $\log$ of GEO N-3. Measurements were taken every 6 m with a precision of $0.01^{\circ} \mathrm{C}$ by Geotech Data on $8 / 18 / 86$. Data plotted at 10-m intervals.

PIGURE 11 Sumary of all temperature data obtained below 500 $m$ in GEO N-3. Note the highest MRT temperature reading colncldes with the artesian aquifer (compare Figure 9 ).

FIGURE 12 Thermal conductivity from GBO N-3. wote the generallzed lithologic log shows a rhyodacitic flow unit centered at 1,100 (compare Figure 9) and that the remalnder of the core hole is essentlally a series of basaltic andesite flows. Data from Geotech Data. 
FIGURE 13 Potassium-argon age dates from GBO $\mathrm{N}-3$. Note the agreement among these dates and those from GEO N-1 (Figure 7 ) and the surface samples (Figure 2 ).

FIGURE 14 Silica content of flulds taken from GEO N-3. Note the increase in sillca below $1,100 \mathrm{~m}$ and that all downhole samples are contaminated by drilling fluids.

FIGURE 15 Distribution of anomalous constituents of fluids taken at intervals of about 75 from GEO N-3. Chemical species used in constructing this figure are $\mathrm{Si}, \mathrm{Bg}, \mathrm{K}, \mathrm{Al}, \mathrm{Sr}, \mathrm{B}$, and $\mathrm{F}$. The highest $10 \mathrm{z}$ of each of the species are considered anomalous and their distribution plotted as a function of depth in histogram form. The shaded area reflects the depth distribution of sample depths. The difference between the two should qualitatively reflect drilling flulds mixing with formation fluids. Note that effects of geothermal fluids are basically lacking above 915 in (compare with Figure 9 ). 


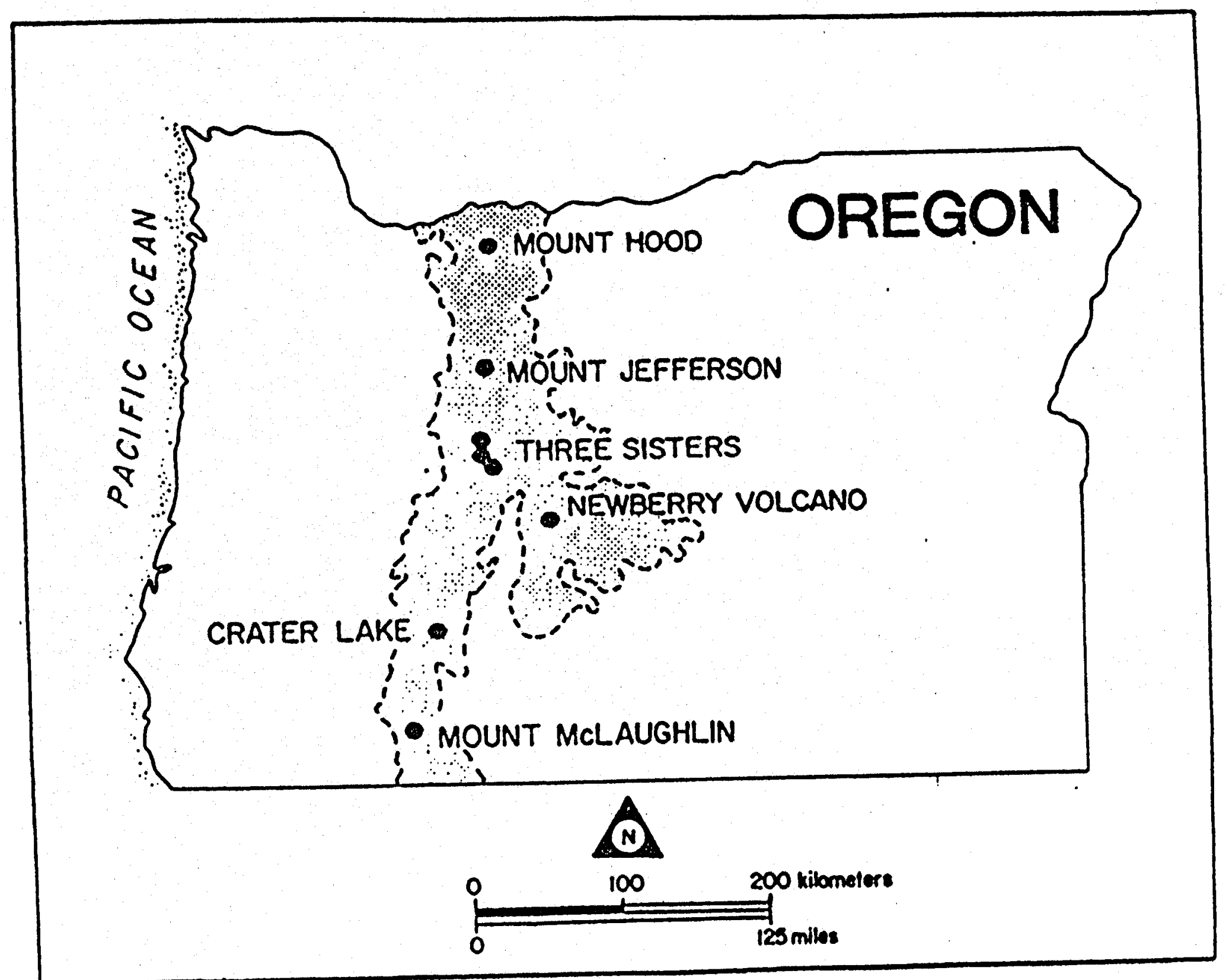




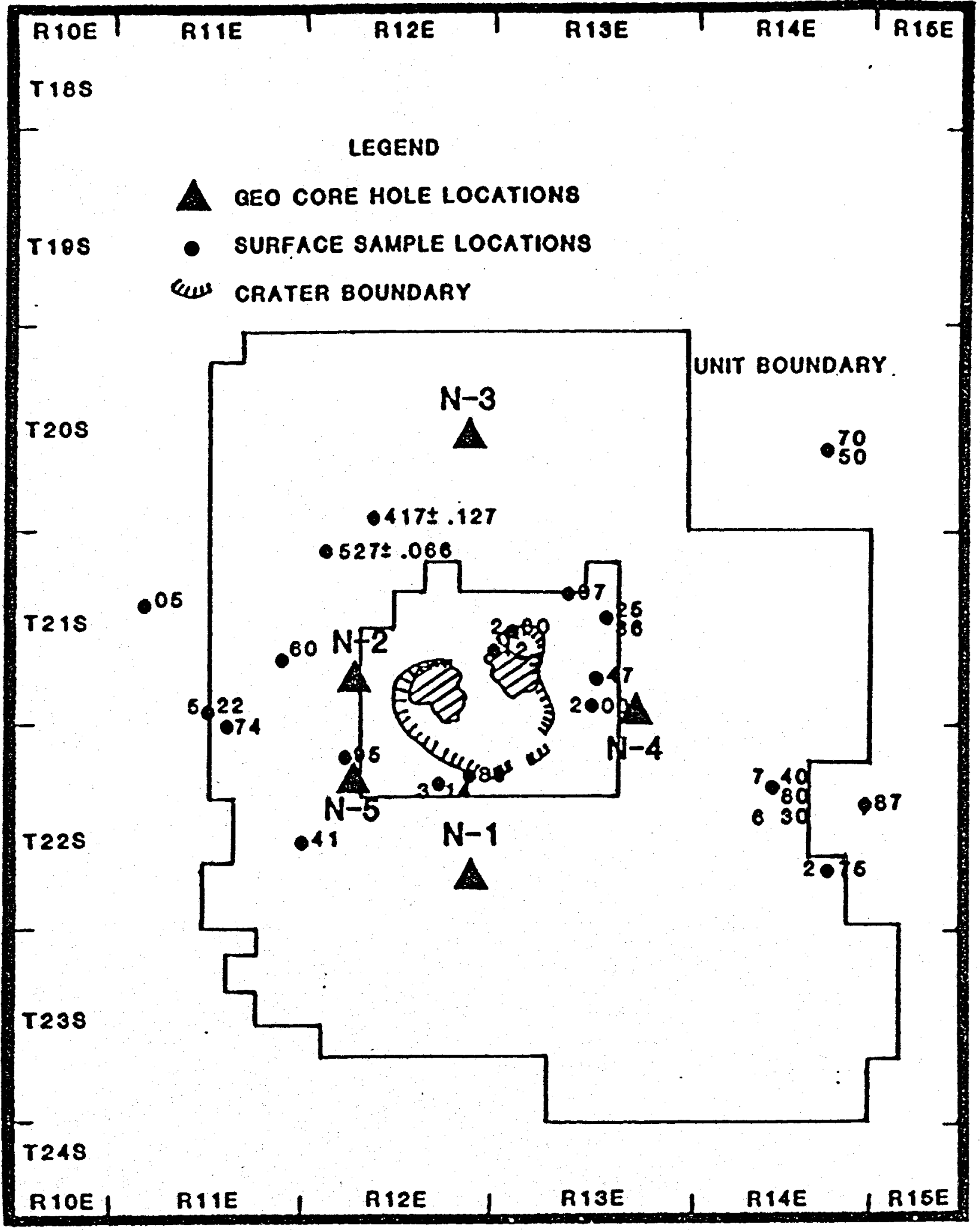


TEMPERATURE $\left({ }^{\circ} \mathrm{F}\right)$

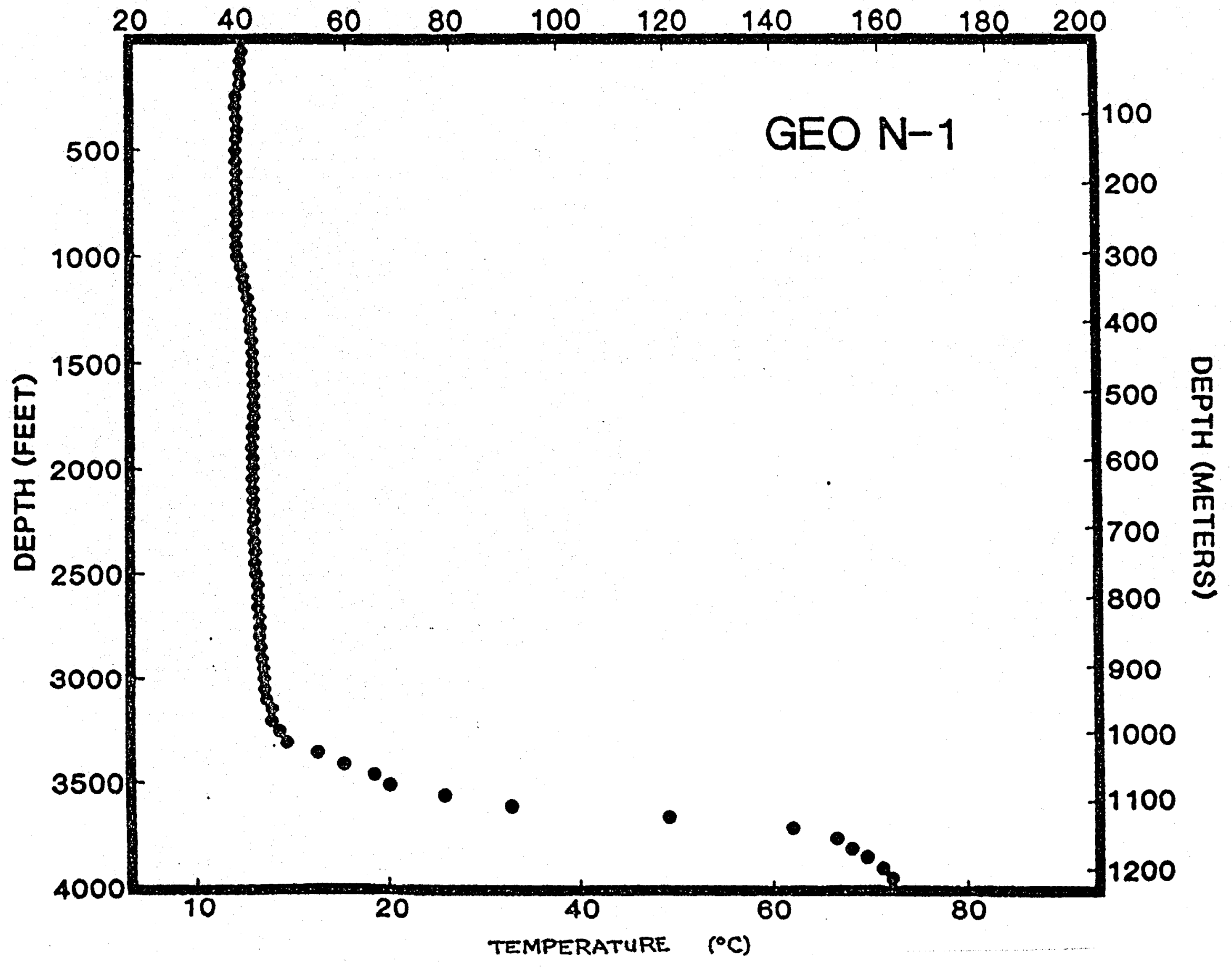




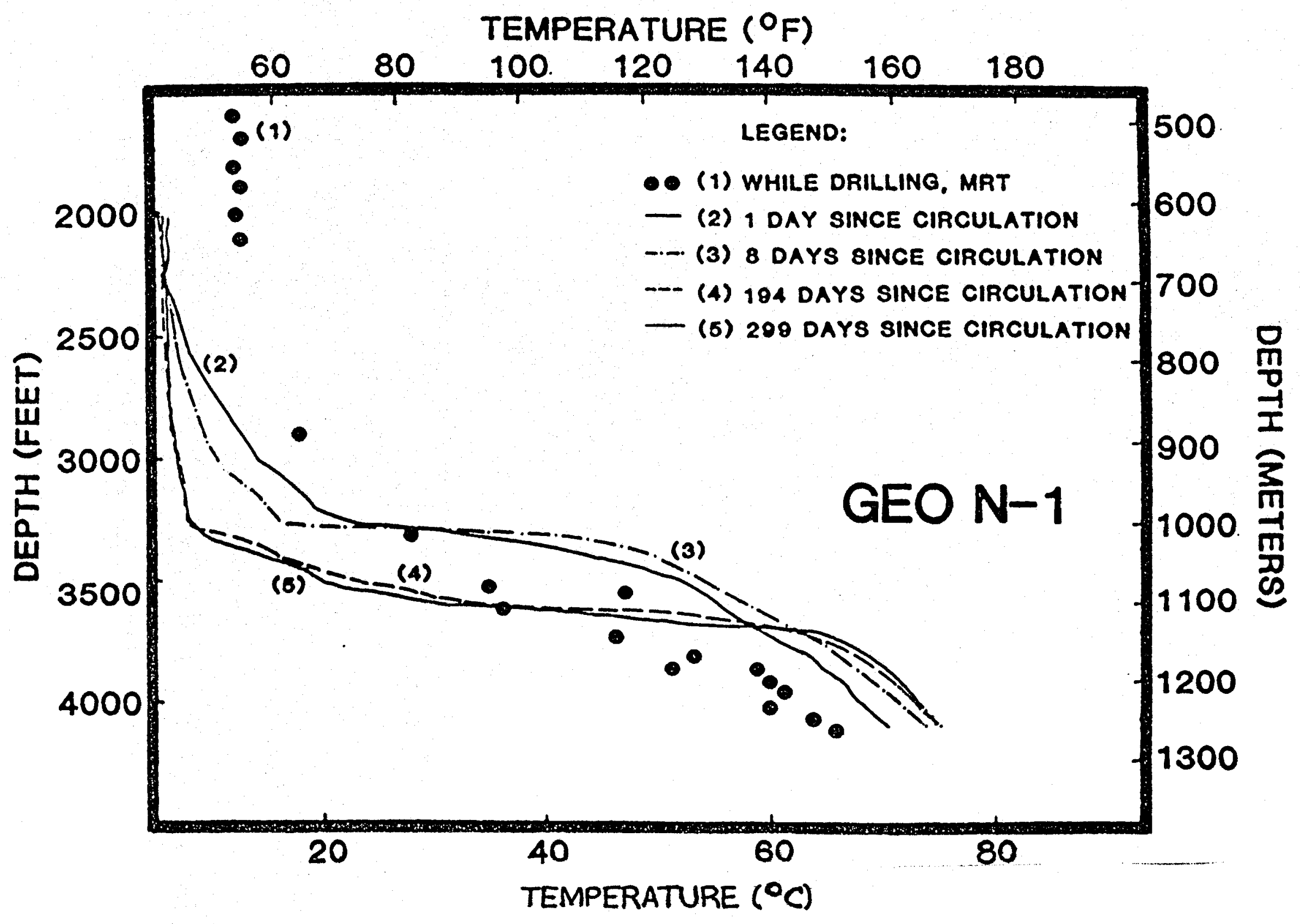




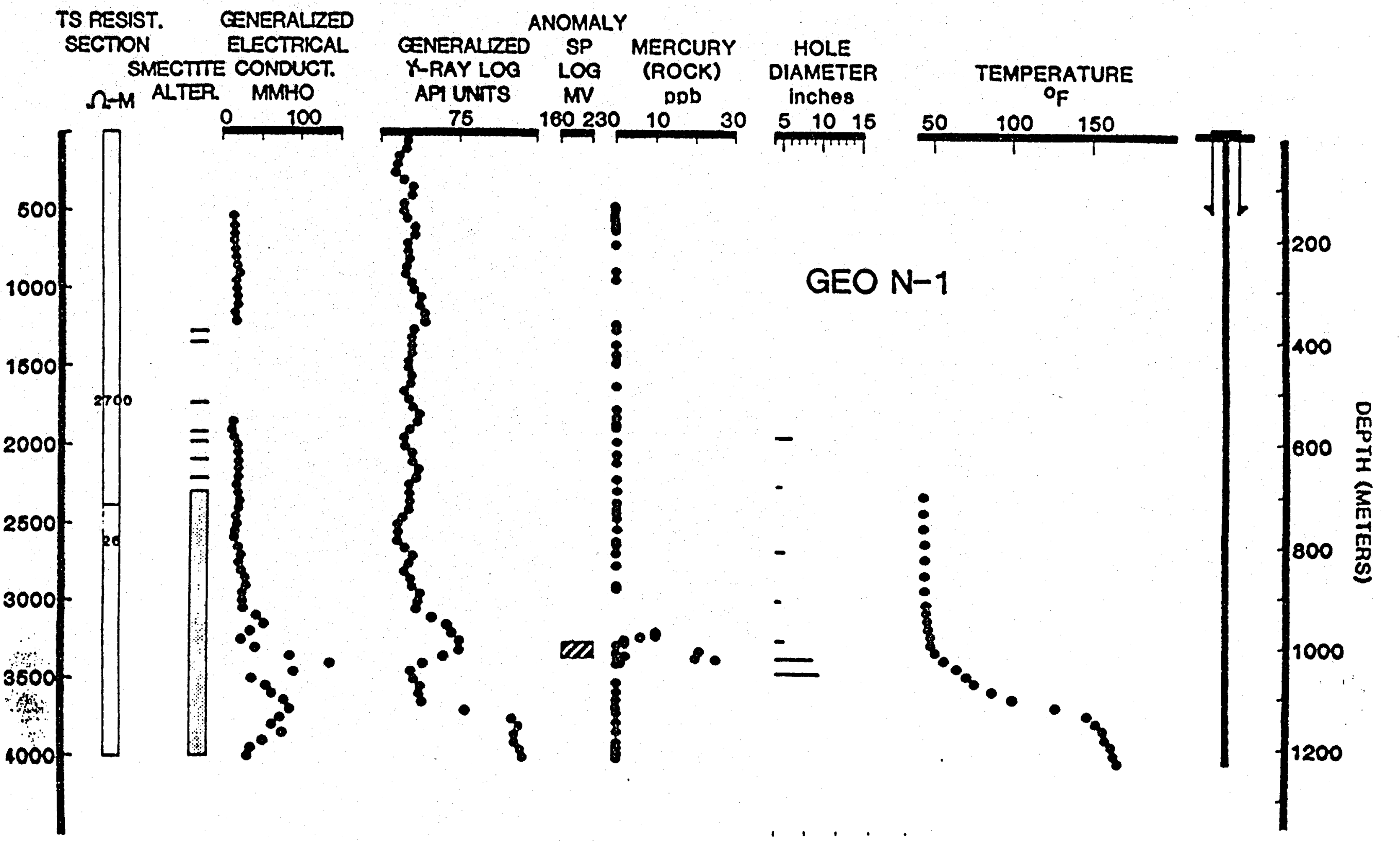




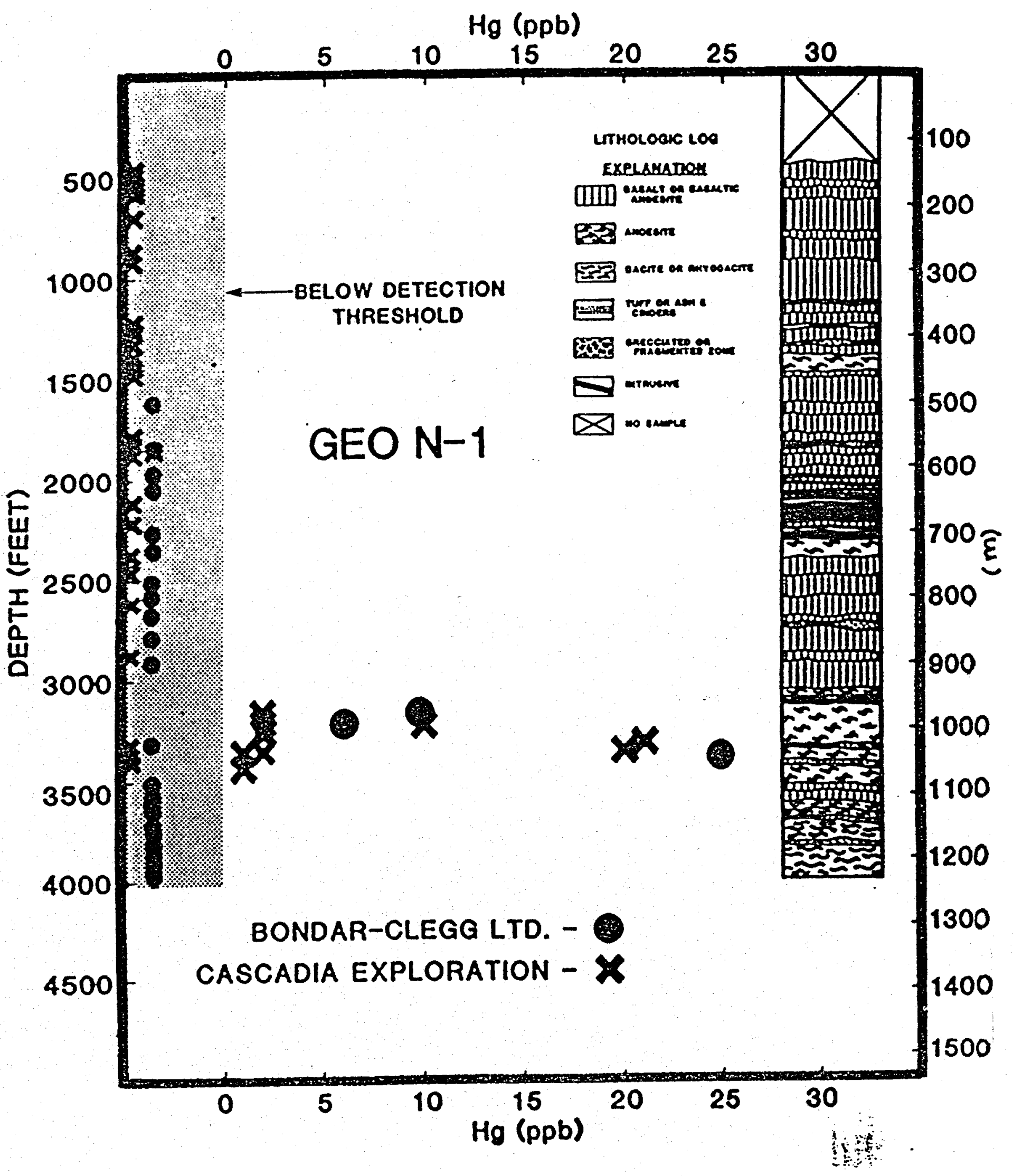




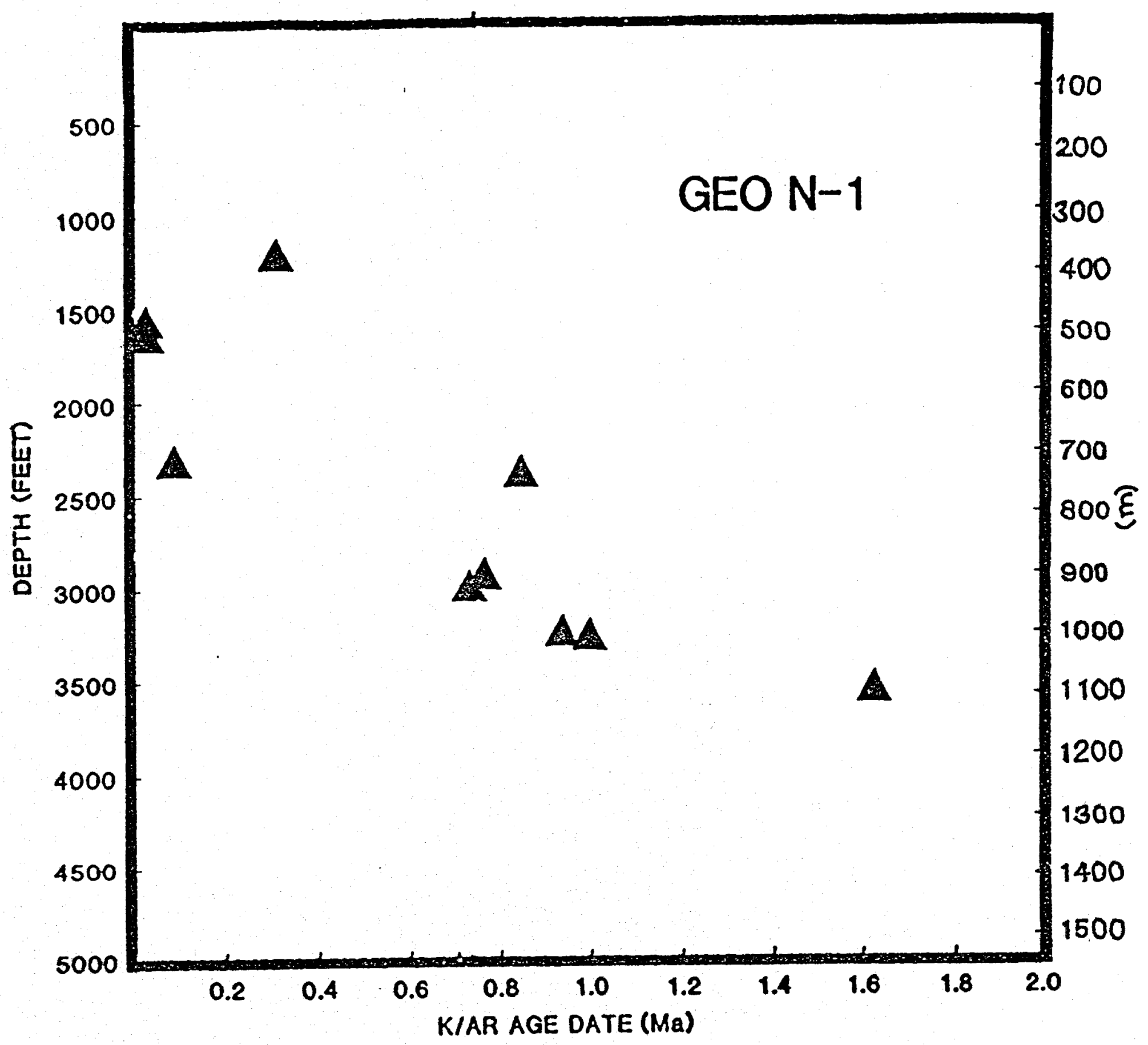




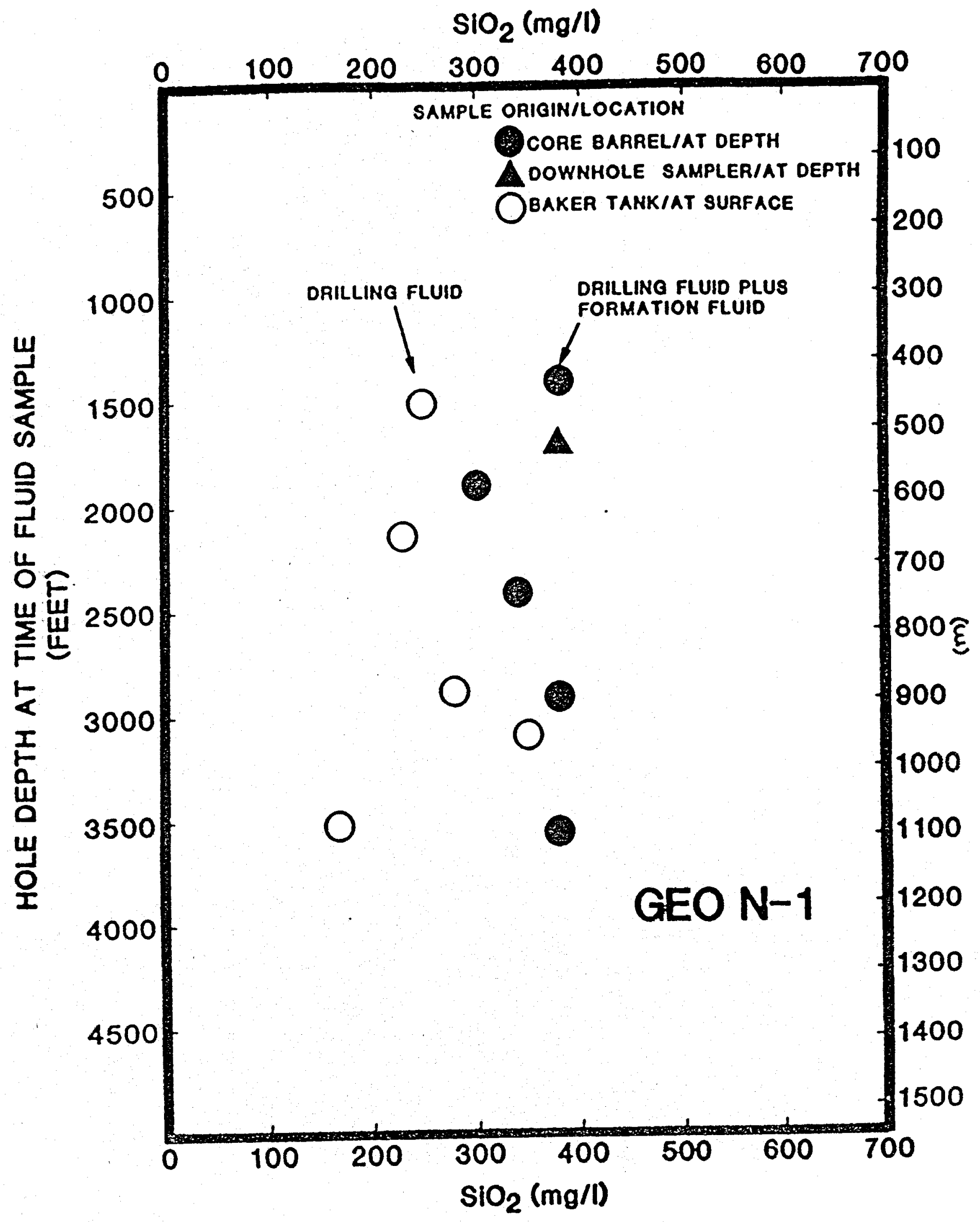




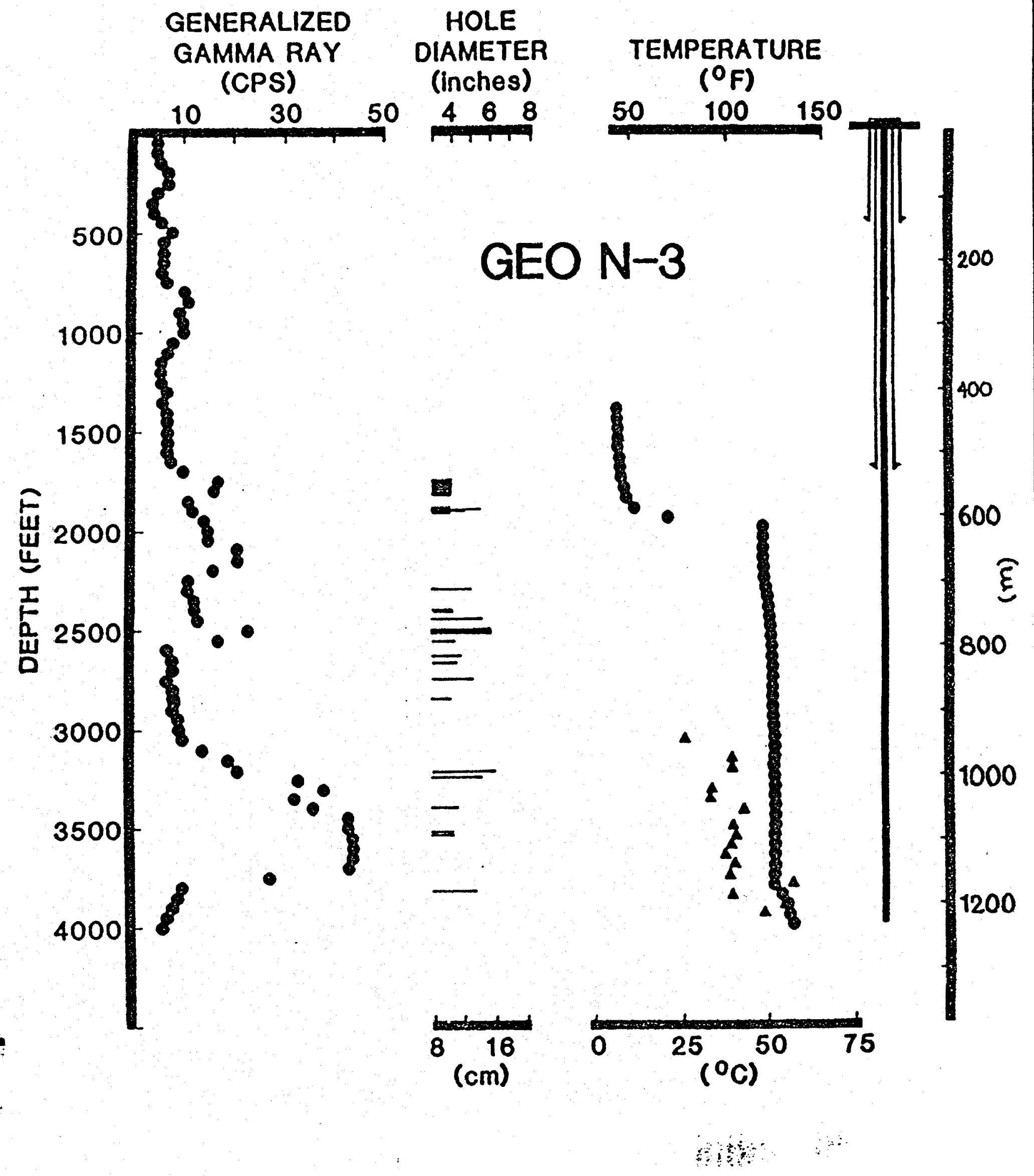




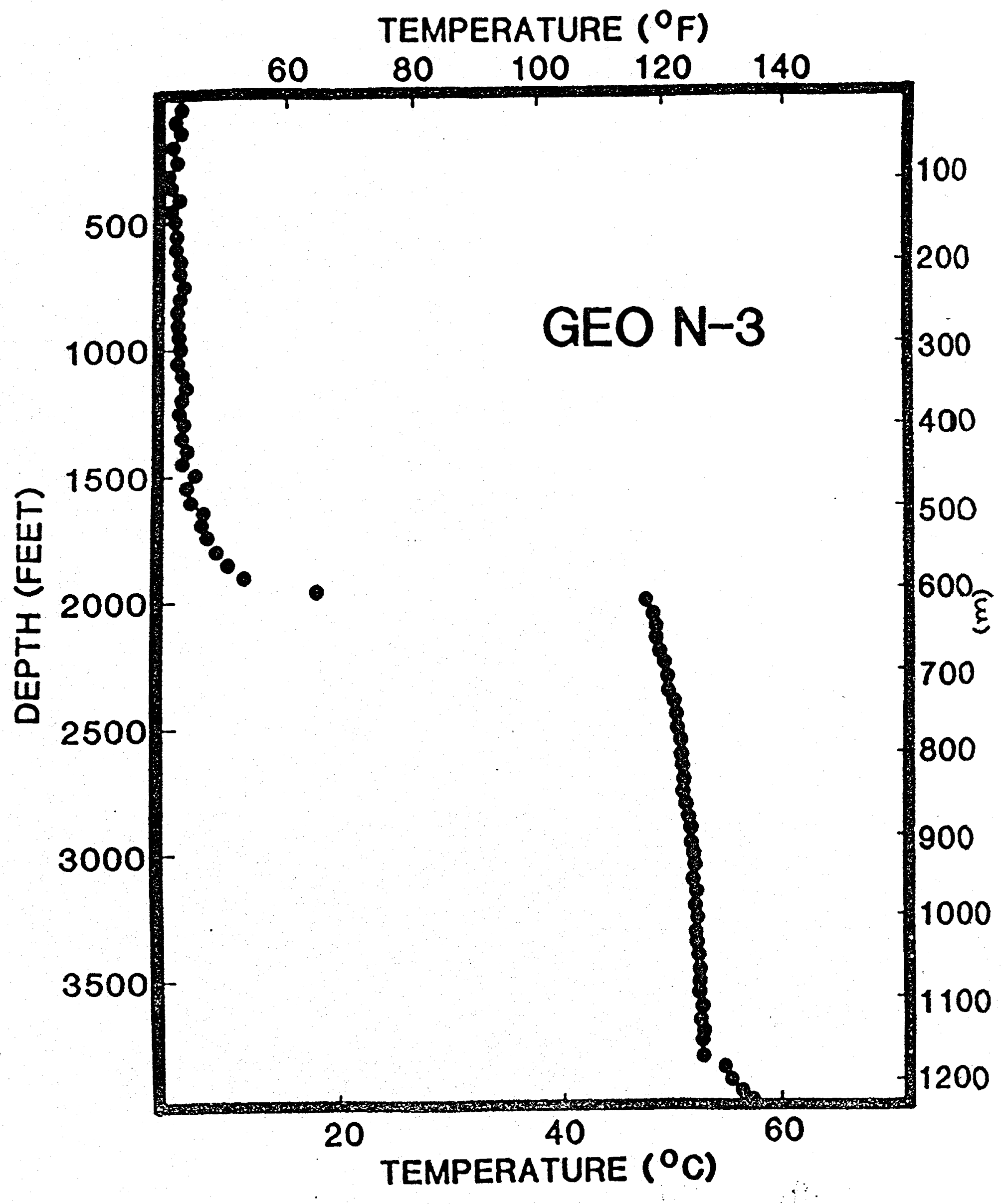




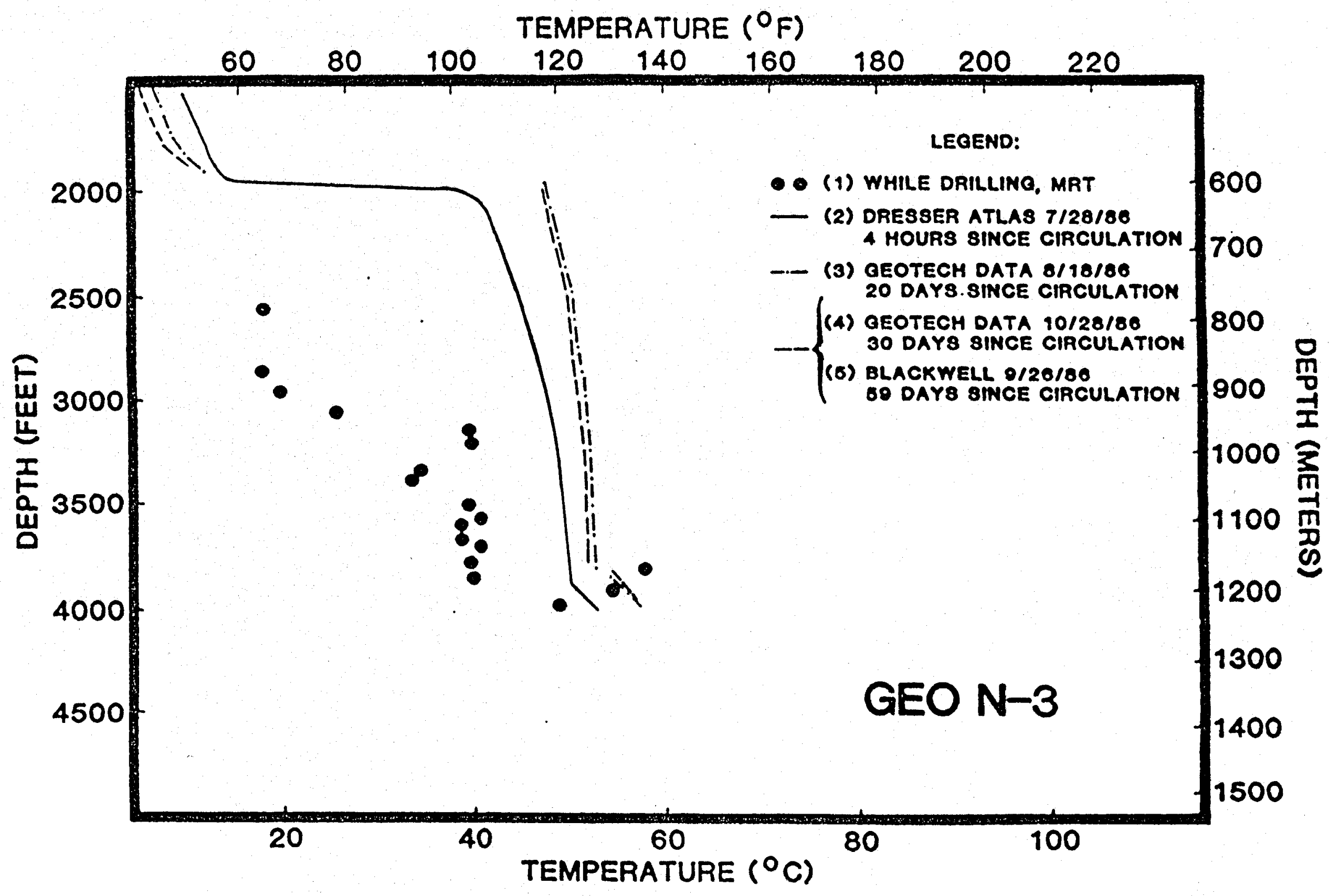




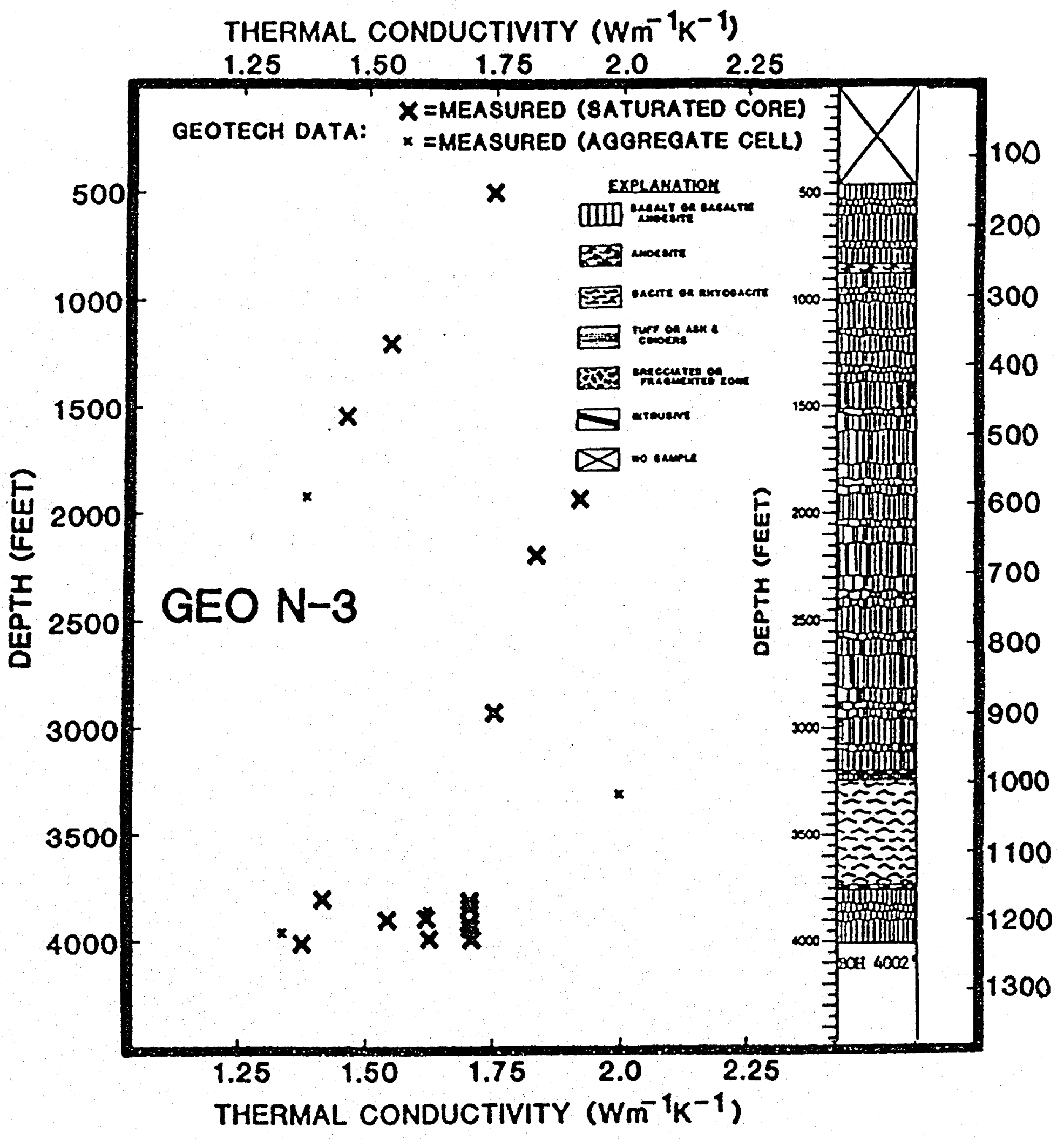




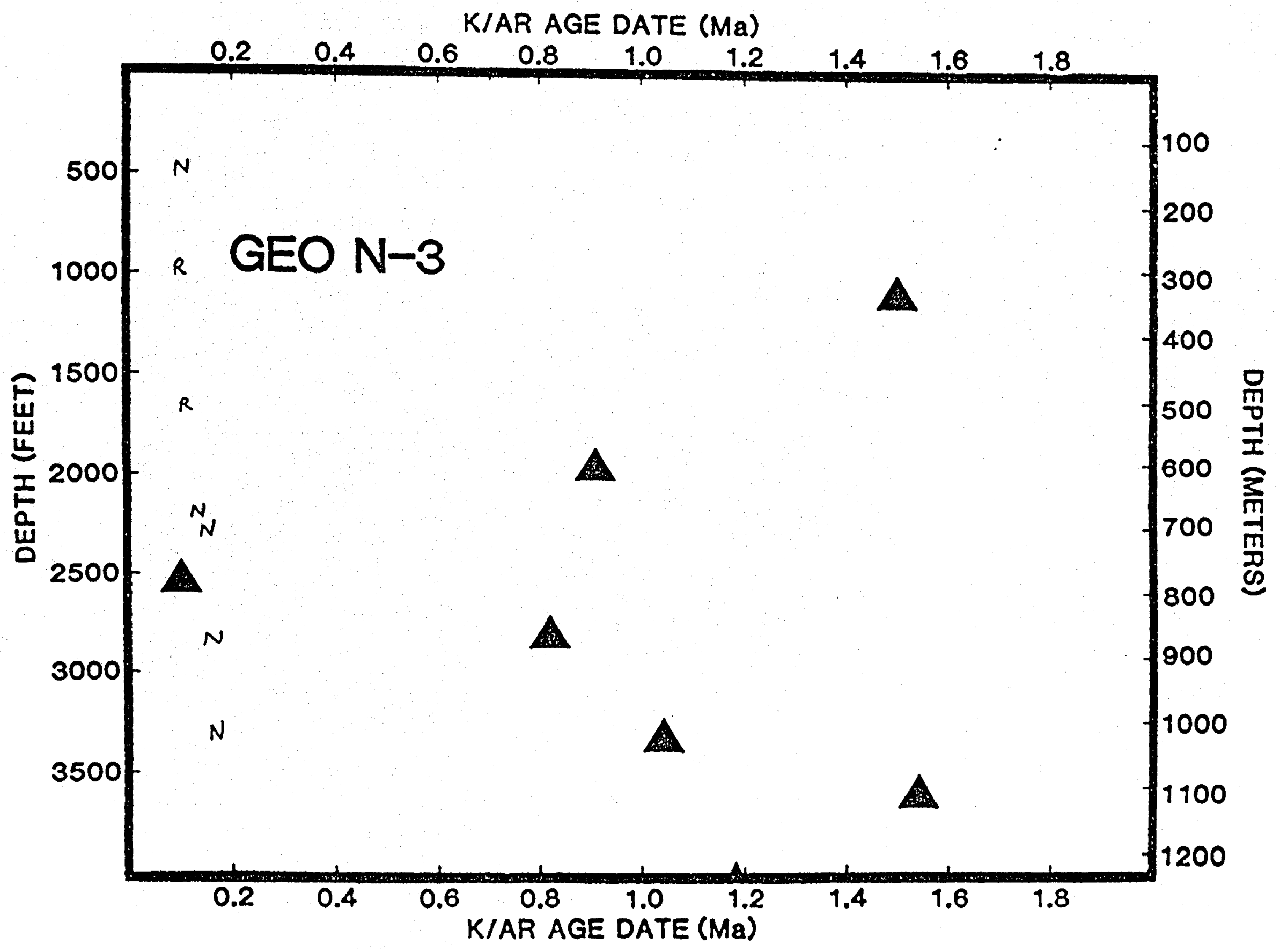




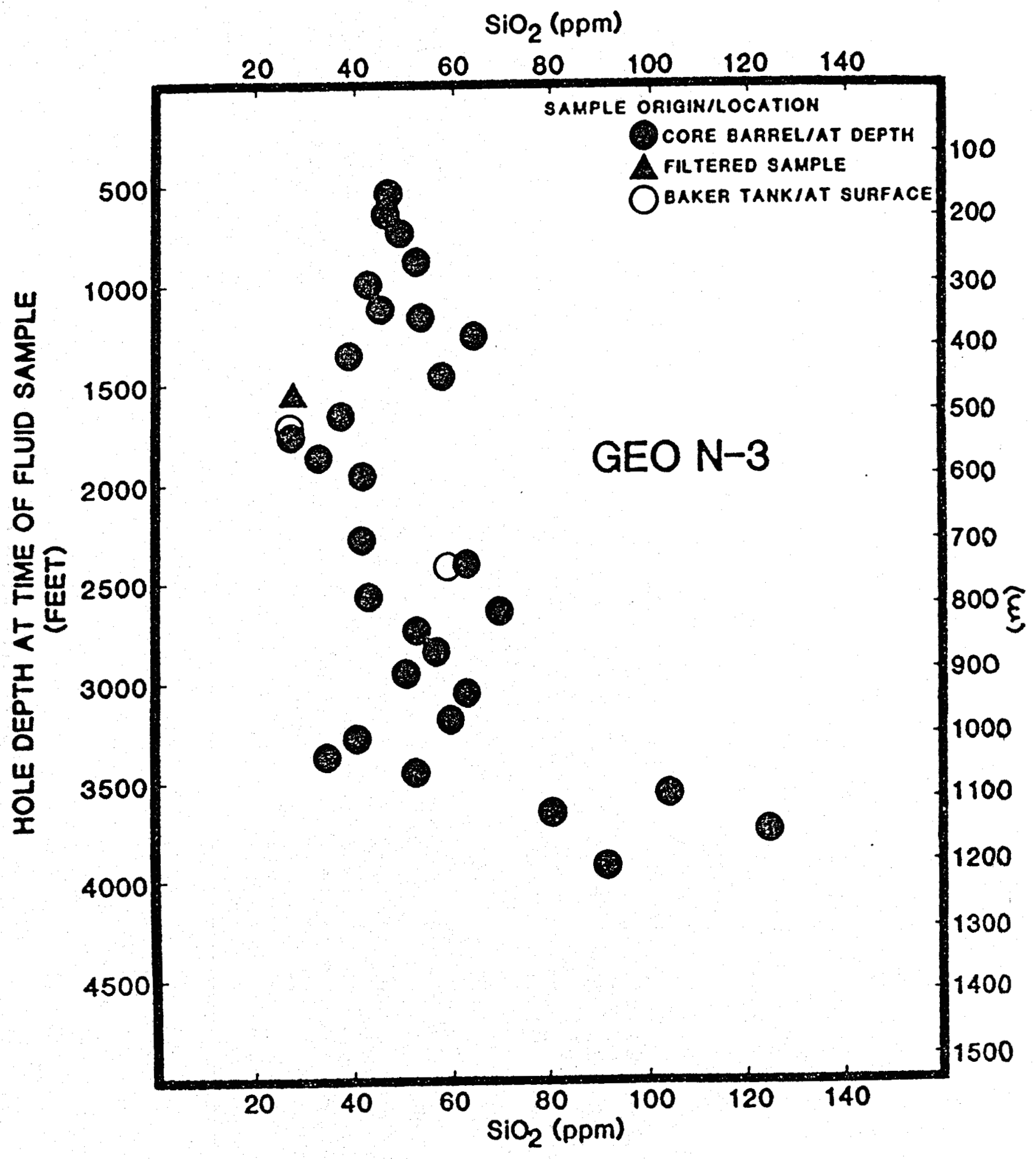




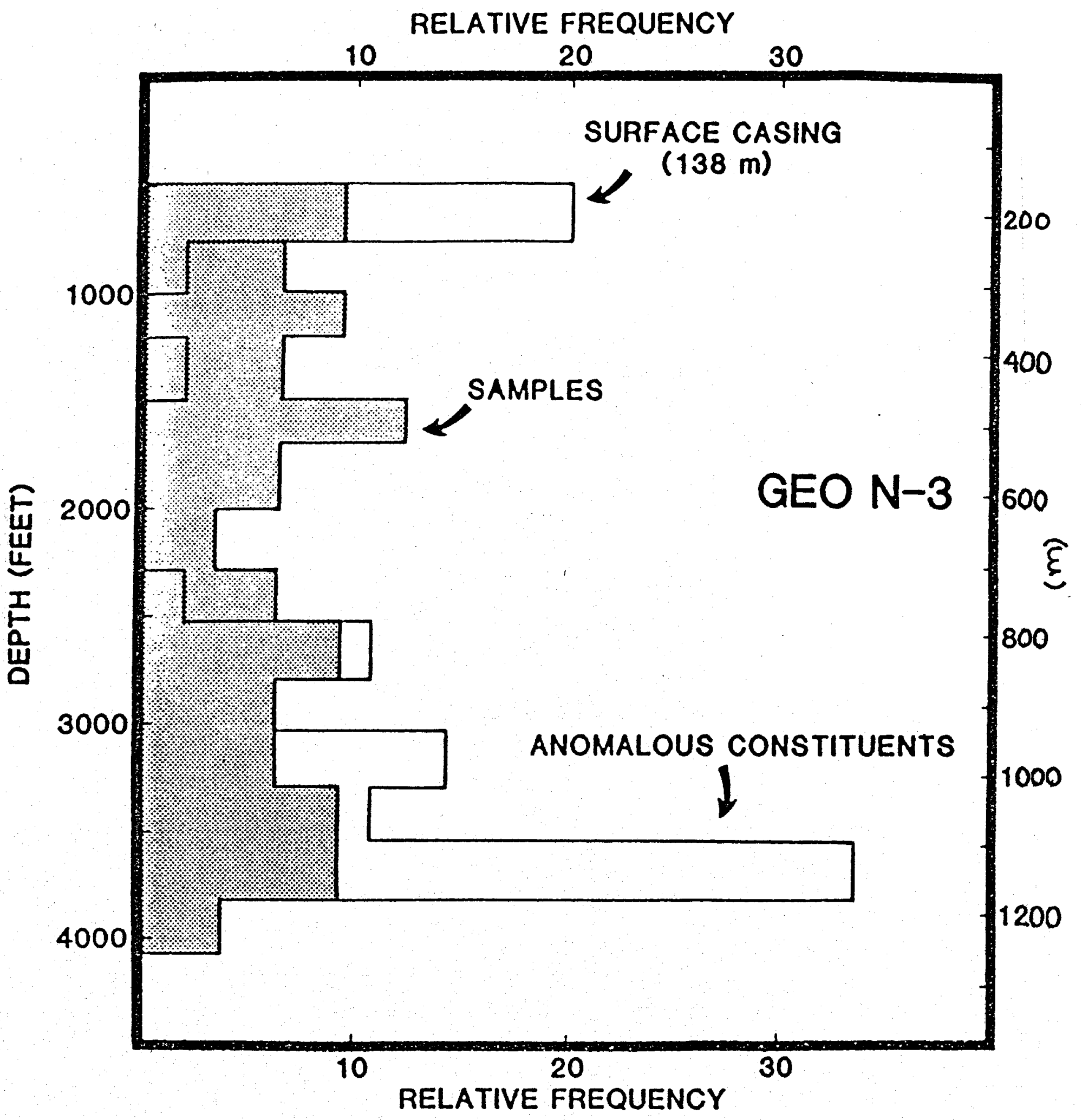




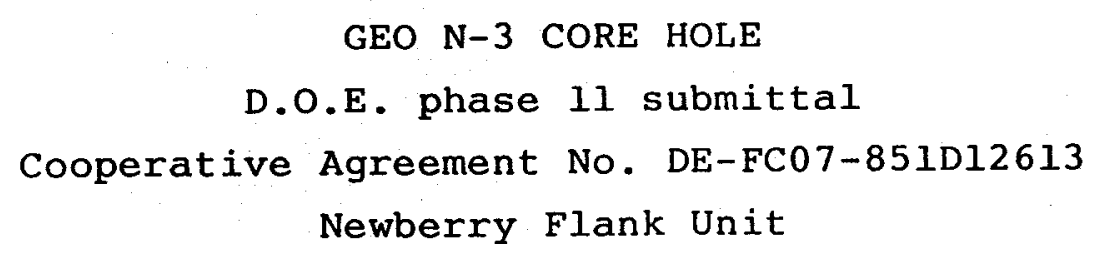




\section{FIGURE C2}

GEOCHEMISTRY OF FLUIDS IN CORE HOLE GEO N-3. Fluid samples of the borehole were routinely collected from the core barrel during core retrieval. Clearly, these fluids are primarily drilling muds. However, value above background suggest the presence of aquifers which contribute formation fluids. Although Figure C2 illustrates only silica values, analyses were conducted for a variety of constituents (Table C2). Fluid samples were also collected from Baker tanks. Note that increasing silica content of fluids correlate with a conductive temperature gradient at 3700-3800 feet (see temperature profile Figure B6). 


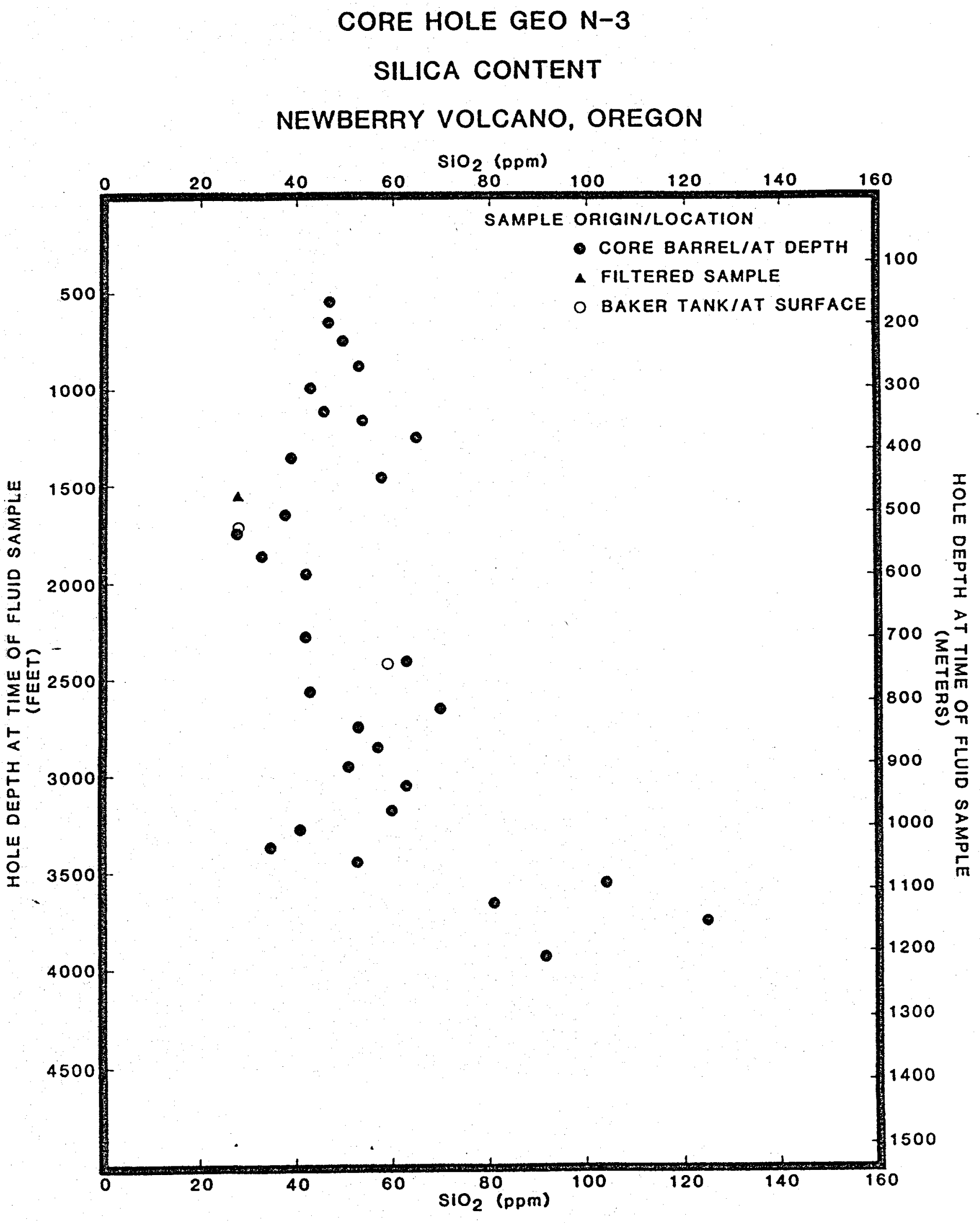

Figure C2 


\section{$\therefore$ C2}

Fluid Geochemistry for Core Hole GEO N-3

\begin{tabular}{|c|c|c|c|c|c|c|c|c|c|c|}
\hline \multirow[b]{2}{*}{ Sample } & \multirow[b]{2}{*}{ Descriptor } & \multicolumn{7}{|c|}{ PPM } & \multirow[b]{2}{*}{$\mathrm{ZN}$} & \multirow[b]{2}{*}{ B } \\
\hline & & $B A$ & V & Ag & $\mathrm{Li}$ & LA & $C E$ & MN & & \\
\hline 1 & $549^{\prime}$ & - & - & 0.06 & - & 0.1 & 0.5 & - & - & - \\
\hline 2 & $668^{\prime}$ & - & - & 0.07 & - & 0.2 & 0.5 & - & - & - \\
\hline 3 & $746^{\circ}$ & 2.1 & - & 0.10 & 0.09 & 0.2 & 0.7 & - & - & - \\
\hline 4 & $866^{\prime}$ & - & 1.0 & 0.08 & - & 0.2 & 0.5 & - & - & - \\
\hline 5 & $982^{\prime}$ & - & - & 0.07 & - & 0.1 & 0.4 & - & - & - \\
\hline 6 & $1113^{\prime}$ & - & - & 0.06 & - & 0.1 & 0.5 & - & - & - \\
\hline 7 & $1172^{\circ}$ & - & - & 0.07 & - & 0.2 & 0.5 & - & - & - \\
\hline 8 & $1242^{\prime}$ & - & - & 0.07 & - & 0.2 & 0.4 & - & - & - \\
\hline 9 & $1345^{\prime}$ & - & 1 & 0.08 & - & 0.2 & 0.5 & - & - & - \\
\hline 10 & 1462 & - & - & - & 0.05 & - & 0.2 & - & - & - \\
\hline 11 & $\star 1549.5^{\prime}$ & - & - & 0.06 & - & 0.1 & 0.4 & - & - & - \\
\hline 12 & 1637.5 & - & - & 0.06 & - & 0.1 & 0.4 & - & - & - \\
\hline 13 & $\star \star 1710^{\circ}$ & - & - & 0.05 & - & - & 0.4 & - & - & - \\
\hline 14 & $1740.5^{\circ}$ & - & - & 0.05 & - & - & 0.4 & - & - & - \\
\hline 15 & $1859.5^{\prime}$ & - & - & 0.06 & - & 0.1 & 0.4 & - & - & - \\
\hline 16 & $1969^{\circ}$ & - & - & 0.05 & - & $\therefore$ & 0.4 & - & - & - \\
\hline 17 & $2271^{\prime}$ & - & - & - & - & - & 0.4 & - & - & - \\
\hline 18 & $2402^{\prime}$ & - & - & - & - & - & 0.4 & - & - & - \\
\hline 19 & $\star \star 2409^{\prime}$ & - & - & - & - & - & 0.3 & - & - & - \\
\hline 20 & $2557^{\prime}$ & - & - & - & - & - & 0.3 & - & - & - \\
\hline 21 & $2641.5^{\prime}$ & - & - & - & - & - & - & 0.4 & - & - \\
\hline 22 & $2742^{\circ}$ & - & - & - & - & - & 0.3 & - & 0.2 & - \\
\hline 23 & $2842^{\prime}$ & - & - & - & - & - & 0.3 & - & - & - \\
\hline 24 & $2948^{\prime}$ & - & - & - & - & - & 0.3 & - & - & - \\
\hline 25 & $3041^{\prime}$ & - & - & - & - & - & 0.3 & - & - & - \\
\hline 26 & $3173^{\circ}$ & - & - & - & 0.19 & - & - & - & - & 4.9 \\
\hline 27 & $3276^{\circ}$ & - & - & - & - & - & 0.3 & - & - & 0.3 \\
\hline 28 & $3364^{\circ}$ & - & - & - & - & - & 0.4 & - & - & - \\
\hline 29 & $3440^{\prime}$ & - & 1 & 0.08 & 0.05 & 0.2 & 0.6 & - & - & - \\
\hline 30 & $3542^{\prime}$ & 0.9 & - & - & 0.07 & - & - & 0.8 & 1.1 & - \\
\hline 31 & $3652^{\prime}$ & - & - & - & - & - & - & - & - & - \\
\hline 32 & $3743^{\prime}$ & - & - & - & - & - & - & - & 0.3 & - \\
\hline 33 & $3923^{\prime}$ & - & - & - & - & - & - & - & - & 0.1 \\
\hline 34 & $\star \star \star *$ & - & - & - & - & - & 0.3 & - & - & - \\
\hline
\end{tabular}

\footnotetext{
- below detection limits

* filtered

* * Bakertank

***no depth reported
} 
TALLE C2

Fluid Geochemistry for Core Hole GEO N-3

\begin{tabular}{|c|c|c|c|c|c|c|c|c|c|c|c|c|}
\hline \multirow[b]{2}{*}{ Sample } & \multirow[b]{2}{*}{ Descriptor } & \multirow{2}{*}{$\begin{array}{l}\text { ppm } \\
\text { CL }\end{array}$} & \multirow{2}{*}{$\begin{array}{l}\mathrm{ppb} \\
\mathrm{Hg} \\
\end{array}$} & \multirow{2}{*}{$\begin{array}{l}\text { ppmw } \\
\mathrm{CO}_{2}\end{array}$} & \multirow[b]{2}{*}{$\mathrm{NA}$} & \multirow[b]{2}{*}{$\underline{\mathrm{K}}$} & \multicolumn{3}{|c|}{ PPM } & \multirow[b]{2}{*}{$\underline{A L}$} & \multirow[b]{2}{*}{ Sion } & \multirow[b]{2}{*}{$\underline{S R}$} \\
\hline & & & & & & & $\mathrm{CA}$ & $\mathrm{Mg}$ & $\underline{\mathrm{Fe}}$ & & & \\
\hline 1 & $549^{\circ}$ & 15 & - & 412 & 143 & 1 & 0.9 & - & 0.1 & 1.3 & 47 & 0.04 \\
\hline$\overline{2}$ & $668^{\circ}$ & 6 & - & 344 & 119 & 1 & 0.7 & - & 0.08 & - & 47 & 0.04 \\
\hline 3 & $746^{\prime}$ & 5 & - & 315 & 221 & $\overline{3}$ & 4 & 1.0 & 0.93 & 2.5 & 50 & 0.24 \\
\hline 4 & $866^{\prime}$ & 6 & - & 386 & 135 & 1 & 0.6 & - & 0.03 & - & 53 & 0.04 \\
\hline 5 & $982^{\prime}$ & 3 & - & 364 & 122 & 1 & 1 & - & 0.08 & 1.3 & 43 & 0.05 \\
\hline 6 & $1113^{\circ}$ & 3 & - & 371 & 141 & 1 & 1 & - & 0.12 & 1.4 & 46 & 0.04 \\
\hline 7 & $1172^{\circ}$ & 8 & - & 383 & 144 & 1 & 0.9 & - & 0.02 & - & 54 & 0.04 \\
\hline 8 & 1242 & 3 & - & 367 & 164 & 1 & 0.6 & - & 0.03 & 0.6 & 65 & 0.04 \\
\hline 9 & $1345^{\circ}$ & 4 & - & 257 & 95 & $\overline{1}$ & 1 & 0.6 & 0.05 & 0.7 & 39 & 0.03 \\
\hline 10 & $1462^{\prime}$ & 3 & - & 223 & 168 & 1 & 2 & 0.7 & 0.64 & 1.1 & 58 & 0.04 \\
\hline 11 & $\star 1549.5^{\prime}$ & 4 & 1.4 & 208 & 67 & - & 0.9 & - & - & - & 28 & 0.03 \\
\hline 12 & $1637: 5^{\prime}$ & 4 & 1.4 & 285 & 72 & - & 1.0 & - & 0.03 & 0.6 & 38 & 0.03 \\
\hline 13 & $* * 1710^{\prime}$ & 4 & 1.7 & 306 & 66 & - & 0.5 & - & - & - & 28 & 0.01 \\
\hline 14 & $1740.5^{\prime}$ & 6 & 1.7 & 246 & 69 & - & 0.5 & - & - & - & 28 & 0.01 \\
\hline 15 & $1859.5 !$ & 5 & 1.9 & 199 & 68 & - & 0.6 & - & - & - & 33 & 0.01 \\
\hline 16 & $1969^{\circ}$ & 4 & 64 & 293 & 70 & - & 0.9 & - & 0.06 & - & 42 & 0.02 \\
\hline 17 & 2271 & 4 & 1.8 & 255 & 98 & - & 0.6 & - & - & - & 42 & 0.02 \\
\hline 18 & $2402^{\prime}$ & 5 & 1.7 & 292 & 119 & - & 1.0 & - & 0.21 & 1.0 & 63 & 0.04 \\
\hline 19 & $* \star 2409^{\prime}$ & 11 & 2.0 & 224 & 128 & 1 & 1 & - & 0.18 & 0.9 & 59 & 0.04 \\
\hline 20 & $2557^{\prime}$ & 7 & - & 395 & 91 & - & 0.9 & - & 0.03 & - & 43 & 0.03 \\
\hline 21 & $2641.5^{\prime}$ & 4 & - & 315 & 258 & - & 7 & 2 & 0.24 & - & 70 & 0.10 \\
\hline 22 & $2742^{\prime}$ & 4 & 3.7 & 277 & 118 & - & 1 & - & 0.49 & 0.9 & 53 & - \\
\hline 23 & $2842^{\prime}$ & 4 & 3.5 & 264 & 116 & - & 0.8 & - & 0.90 & 0.7 & 57 & 0.02 \\
\hline 24 & $2948^{\prime}$ & 6 & 1.6 & 265 & 115 & 1 & 1 & 0.6 & 0.21 & 1.2 & 51 & 0.03 \\
\hline 25 & $3041^{\prime}$ & 6 & 1.6 & 596 & 137 & $I$ & 1 & - & 0.14 & 1.0 & 63 & 0.03 \\
\hline 26 & $3173^{\prime}$ & 108 & $=$ & 304 & 438 & $2 \overline{0}$ & 7 & 16 & 0.10 & - & 60 & 0.14 \\
\hline 27 & $3276^{\prime}$ & 18 & 1.9 & 272 & 127 & 1 & 1 & - & 0.05 & 0.61 & 41 & 0.04 \\
\hline 28 & 3364 ' & 5 & 1.9 & 267 & 101 & - & 0.5 & - & - & - & 35 & 0.02 \\
\hline 29 & $3440^{\prime}$ & 6 & 1.7 & 741 & 112 & 2 & 1 & 0.6 & 0.08 & 0.9 & 53 & 0.04 \\
\hline 30 & $3542^{\prime}$ & 18 & - & 241 & 720 & 3 & 29 & 7 & 5.79 & - & 104 & 0.41 \\
\hline 31 & $3652^{\prime}$ & 3 & 4.0 & 273 & 207 & - & 3 & 1 & 0.76 & 1.5 & 81 & 0.09 \\
\hline 32 & $3743^{\prime}$ & 6 & 3.5 & 230 & 224 & - & 3 & 1 & 1.83 & 4.1 & 125 & 0.07 \\
\hline 33 & $3923^{1}$ & - & - & 232 & 167 & - & 2 & 1.0 & 0.85 & 2.4 & 92 & 0.06 \\
\hline 34 & $\star \star \star$ & - & - & - & 145 & - & 2 & 1 & 1.1 & 2.9 & 104 & 0.05 \\
\hline
\end{tabular}

- below detection limits

* filtered

** Bakertank

*** no depth reported 


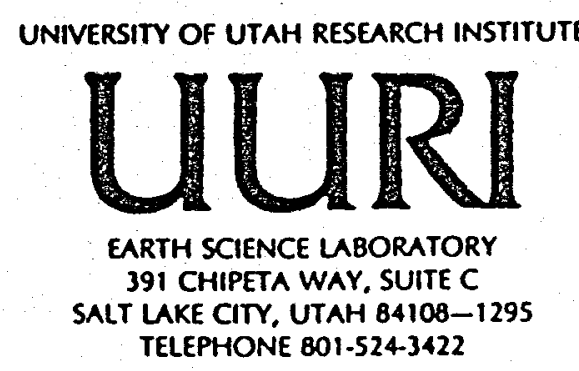

October 15, 1986

Thermochem, Inc.

6119 0ld Redwood Hwy., Suite A-2

Santa Rosa, CA 95401

$707575-1310$

Attention: Paul Hirtz

REPORT

\begin{tabular}{|c|c|c|c|c|c|}
\hline Sample & $\begin{array}{l}\text { ppm } \\
\text { Cl }\end{array}$ & $\begin{array}{l}\mathrm{ppb} \\
\mathrm{Hg}\end{array}$ & Sample & $\begin{array}{l}\mathrm{ppm} \\
\mathrm{Cl}\end{array}$ & $\begin{array}{l}\mathrm{ppb} \\
\mathrm{Hg}\end{array}$ \\
\hline $\begin{array}{r}3340-1 A \\
-3340-2 A \\
3340-3 A \\
3340-4 A \\
3340-5 A \\
3340-6 A \\
3340-7 A \\
3340-8 A \\
3340-9 A \\
3340-10 A \\
3340-11 A \\
3340-12 A \\
3340-13 A \\
3340-14 A \\
3340-15 A \\
3340-16 A \\
3340-17 A\end{array}$ & $\begin{array}{r}15 \\
6 \\
5 \\
6 \\
3 \\
3 \\
8 \\
3 \\
4 \\
3 \\
4 \\
4 \\
6 \\
5 \\
4 \\
4 \\
5\end{array}$ & $\begin{array}{l}<.5 \\
<.5 \\
<.5 \\
<.5 \\
<.5 \\
<.5 \\
<.5 \\
<.5 \\
<.5 \\
<.5 \\
1.4 \\
1.7 \\
1.7 \\
1.9 \\
64 . \\
1.8 \\
1.7\end{array}$ & $\begin{array}{l}3340-18 A \\
3340-19 A \\
3340-20 A \\
3340-21 A \\
3340-22 A \\
3340-23 A \\
3340-24 A \\
3340-25 A \\
3340-26 A \\
3340-27 A \\
3340-28 A \\
3340-29 A \\
3340-30 A \\
3340-31 A \\
3340-32 A \\
3340-33 A\end{array}$ & $\begin{array}{r}11 \\
7 \\
4 \\
4 \\
4 \\
6 \\
6 \\
108 \\
18 \\
5 \\
6 \\
18 \\
3 \\
6 \\
7 \\
4\end{array}$ & $\begin{array}{r}2.0 \\
<0.5 \\
<0.5 \\
3.7 \\
3.5 \\
1.6 \\
1.6 \\
<0.5 \\
1.9 \\
1.9 \\
1.7 \\
<0.5 \\
4.0 \\
3.5 \\
2.6 \\
2.3\end{array}$ \\
\hline
\end{tabular}

Sample \#3340-11A was run on the ICP both filtered and unfiltered. The other two labled filtered ( $\# 3 A$ and $29 A$ ) would not settle. Filtration was necessary in order to analyze them. The remaining samples were decanted.

\section{RECEIVED}

DATE

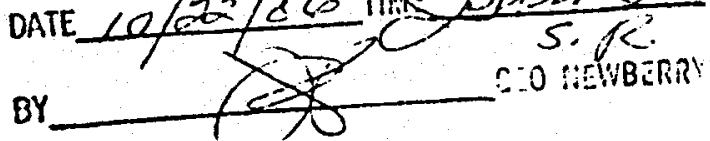

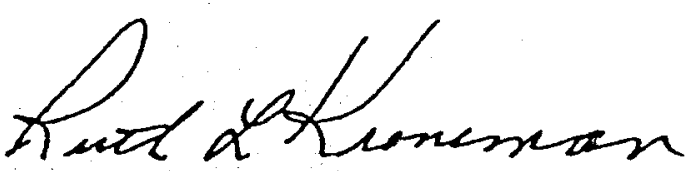

Ruth L. Kroneman Chemist 


\section{Thermochem, Inc.}

Inalytical Laboratory \& Consulting Service

6119 Old Redwood Hwy., Ste. A-2

Santa Rosa, CA 95401

(70) 575.1310

Report of Analysis

Lab Nuaber

$$
\begin{aligned}
& 3340-1 \\
& 3340-2 \\
& 3340-3 \\
& 3340-4 \\
& 3340-5 \\
& 3340-6 \\
& 3340-7 \\
& 3340-8 \\
& 3340-9 \\
& 3340-10 \\
& 3340-11 \\
& 3340-12 \\
& 3340-13 \\
& 3340-14 \\
& 3340-15 \\
& 3340-16 \\
& 3340-17 \\
& 3340-18 \\
& 3340-19 \\
& 3340-20 \\
& 3340-21 \\
& 3340-22 \\
& 3340-23 \\
& 3340-24 \\
& 3340-25 \\
& 3340-26 \\
& 3340-27 \\
& 3340-28 \\
& 3340-29 \\
& 3340-30 \\
& 3340-31 \\
& 3340-32 \\
& 3340-33
\end{aligned}
$$

Descriptor

$\mathrm{N}-3 \quad 549^{\prime}$

412

$N-3 \quad 668^{\prime}$

$\mathrm{N}-3 \mathrm{746^{ \circ }}$

$N-3 \quad 866^{\prime}$

$\mathrm{N}-3 \quad 882^{\prime}$

$\mathrm{N}-3 \quad 113^{\prime}$

$N-3 \quad 1172^{\prime}$

$\mathrm{N}-3 \quad 1242^{\prime}$

$\mathrm{N}-3 \quad 1345^{\prime}$

$N-3 \quad 1462^{\prime}$

$\mathrm{N}-3 \quad 1549^{\circ} .5^{\circ}$

$\mathrm{N}-3 \quad 1637.5^{\prime}$

MUDTANK $1710^{\circ}$

$N-3 \quad 1740.5^{\prime}$

$\mathrm{N}-3 \quad 1850^{\circ} \mathrm{5}^{\prime}$

$N-3 \quad 1969^{\prime}$

$N-3 \quad 2271^{\circ}$

$N-3 \quad 2402^{\prime}$

MUDTANK 2409 ! 224

$N-32557^{\prime} \quad 395$

$\begin{array}{lll}N-3 & 2641.51 & 315\end{array}$

$\begin{array}{ll}N-3 \quad 2742^{\prime} & 277\end{array}$

$\begin{array}{lll}N-3 & 2842^{\prime} & 264\end{array}$

$N-3 \quad 2948^{\circ} \quad 265$

$N-33041^{\prime} \quad 596$

$N-3 \quad 3173^{\prime} \quad 304$

$N-3 \quad 3276$ 2 272

$\mathrm{N}-33364^{\prime} \quad 267$

$\mathrm{N}-3 \quad 3440^{\circ} \quad 741$

$\begin{array}{lll}N-3 & 3542^{\prime} & 241\end{array}$

$N-3 \quad 3652^{\circ} \quad 273$

$N-3 \quad 3743^{\prime} \quad 230$

$\mathrm{N}-3 \quad 3823^{\circ} \quad 232$ 


\section{THEFMOCHEM/GEO}

1

$1 A$

ELEMENT

NA

$\kappa$

$C A$

$M G$

FE

AL.

S102

TI

$F$

SF

IA

$y$

CFi

$M N$

$\mathrm{CO}$

NI

( $\mathrm{Cu}$

$\mathrm{MO}$

$\mathrm{F} \cdot \mathrm{B}$

ZN

CII

AG

AUI

AS

SE

EII

U

TE

SN

W

LI

BE

E

ZF

LA

CE

$\mathrm{TH}$
CONCENTEATION GOH:

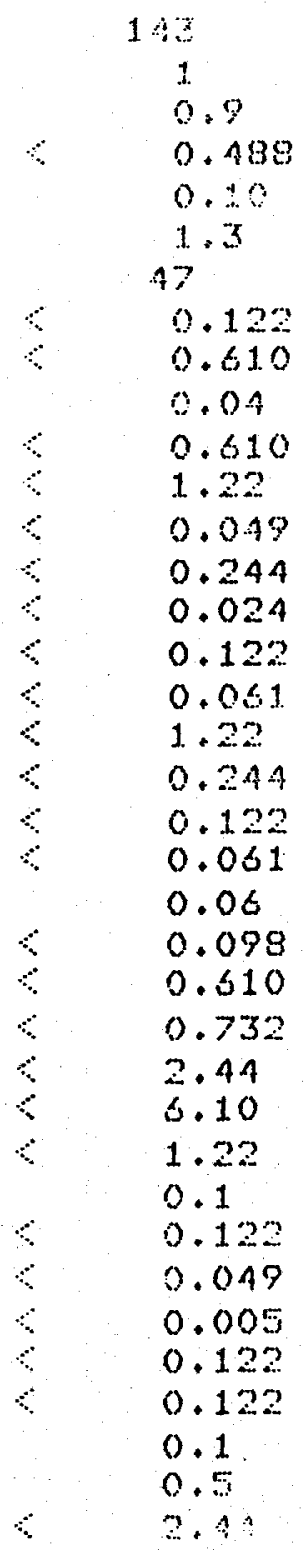


T. - POCLEMEO

2

\section{ELEMENT}

NA

K

$\mathrm{MG}$

FE

AL.

Sro?

TI

$F$

SF

BA

V

Cri

$M N$

$\mathrm{CO}$

$N I$

CUI

MO

$\mathrm{F} \cdot \mathrm{E}$

ZN

$\mathrm{CII}$

$A B$

A.

AS

SE

EII

$u$

TE

Sin

W

LI

BE

B

ZF

LA

CE

$\mathrm{TH}$

\section{GONCENTFATION (FFM)}

119

1.7

0.488

0.08

0.610

47

0.122

0.610

0.04

0.310

1.22

0.049

0.244

0.024

0.122

0.0 .5

1.22

0.244

0.123

0.061

0.07

0.098

0.610

0.732

2.44

6.10

1.22

0.122

0.122

0.049

0.005

0.122

0.122

0.2

0.5

2. ? 


\section{THERMOCHEMGEO}

$3 \quad x \operatorname{mr}$

ELEMEN!

CONOENTEATEON GW

\begin{tabular}{|c|c|c|}
\hline HA & & 21 \\
\hline K゙ & & $x$ \\
\hline $\mathrm{CA}$ & & A \\
\hline$M E$ & & 1.0 \\
\hline$\because E$ & & 0.93 \\
\hline Al. & & 2.5 \\
\hline $\sin$ & & 50 \\
\hline $\mathrm{rr}$ & $<$ & 0.200 \\
\hline$F$ & $<$ & 1.00 \\
\hline SFi & & 0.24 \\
\hline$E A$ & & $2 \cdot 1$ \\
\hline$v$ & 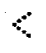 & 2.00 \\
\hline$C F$ & 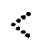 & 0.080 \\
\hline$M N$ & 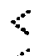 & 0.400 \\
\hline $\mathrm{CO}$ & $\ddots$ & 0.040 \\
\hline$N I$ & く & 0.200 \\
\hline $\mathrm{cu}$ & $\because$ & 0.100 \\
\hline $\mathrm{MO}$ & $\ddots$ & 2.00 \\
\hline$F \cdot E$ & $\lessdot$ & 0.400 \\
\hline$Z N$ & 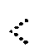 & 0.200 \\
\hline $\mathrm{Cn}$ & $\therefore$ & 0.100 \\
\hline $\mathrm{AG}$ & & 0.10 \\
\hline$A l l$ & $\varkappa$ & 0.160 \\
\hline$A S$ & $\lessdot$ & 1.00 \\
\hline SE & $<$ & 1.20 \\
\hline $\mathrm{BI}$ & $<$ & 4.00 \\
\hline $\mathrm{u}$ & $<$ & 10.0 \\
\hline TE & $<$ & 2.00 \\
\hline$S_{W} N$ & 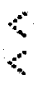 & $\begin{array}{l}0.200 \\
0.200\end{array}$ \\
\hline LI & & 0.09 \\
\hline $\mathrm{EE}$ & 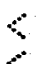 & 0.008 \\
\hline $\mathrm{ZF}$ & $\therefore$ & $\begin{array}{l}0.200 \\
0.200\end{array}$ \\
\hline$\angle A$ & & 0.2 \\
\hline $\begin{array}{l}C E \\
\mathrm{TH}\end{array}$ & & 0.7 \\
\hline
\end{tabular}




\section{T:HEFMOCHEM/GEO}

4

$4 \hat{A}$

ELEMENT

CONCENTFATTON (FFM)

NA

$\kappa$

$C A$

$M G$

FE

AL.

SIO2

TI

$F$

SF:

EA

$\checkmark$

CF:

$M N$

$\mathrm{CO}$

$N I$

(i) $\mathrm{CU}$

FE

ZN-

CII

$A G$

$A U$

AS

SB

BI

U

TE

SN

W

LI

BE

E

ZK

LA

CE

$\mathrm{TH}$

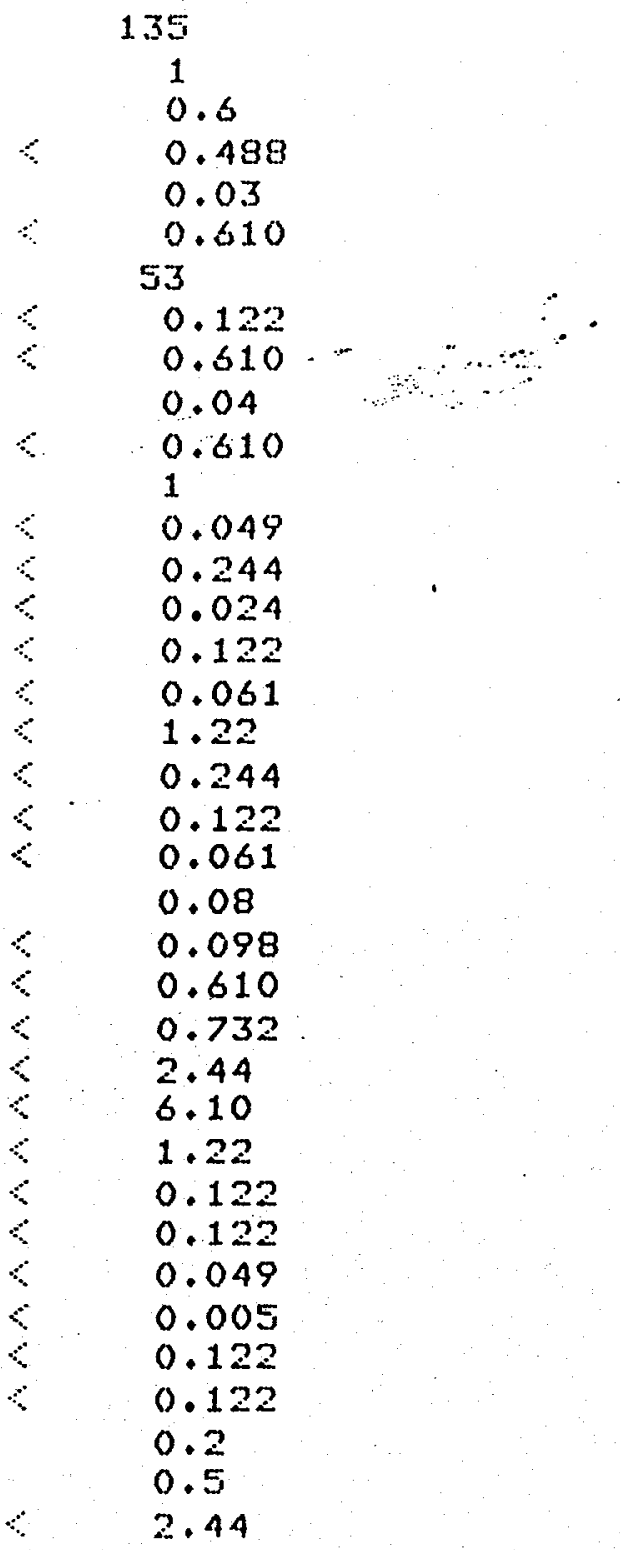




\section{THEFIMOCHEM/GEO}

$5.5 A$

ELEMENT

\section{CONCENTFATION (FFM)}

NA

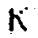

$\mathrm{CA}$

$M G$

FE

AL.

SIOZ

TI

$F$

SFi

EA

U

CF

$\mathrm{HN}$

CO

$N I$

2. $\mathrm{CU}$

MO

$F \cdot B$

ZN

C[I

$A G$

AU

AS

SB

EI

$U$

TE

SN

W

LI

EE

E

ZFi

$L A$

CE

$\mathrm{TH}$

\begin{tabular}{|c|c|}
\hline & 22 \\
\hline & $\begin{array}{l}1 \\
1\end{array}$ \\
\hline$\because$ & $\begin{array}{l}0.488 \\
0.08 \\
1.3\end{array}$ \\
\hline & 43 \\
\hline$<$ & $\begin{array}{l}0.122 \\
0.610 \\
0.05\end{array}$ \\
\hline$\therefore$ & $\begin{array}{l}0.610 \\
1.22\end{array}$ \\
\hline 6 & 0.049 \\
\hline$\therefore$ & $\begin{array}{l}0.244 \\
0.024\end{array}$ \\
\hline$<$ & 0.122 \\
\hline$\therefore$ & $\begin{array}{l}0.061 \\
1.22\end{array}$ \\
\hline$\because$ & 0.244 \\
\hline 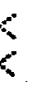 & $\begin{array}{l}0.122 \\
0.061\end{array}$ \\
\hline & 0.07 \\
\hline$\therefore$ & $\begin{array}{l}0.098 \\
0.610\end{array}$ \\
\hline$\because$ & 0.732 \\
\hline$\therefore$ & $\begin{array}{l}2.44 \\
6.10\end{array}$ \\
\hline K & 1.22 \\
\hline 6 & $\begin{array}{l}0.122 \\
0.122\end{array}$ \\
\hline 6 & 0.049 \\
\hline$\because$ & $\begin{array}{l}0.005 \\
0.122\end{array}$ \\
\hline & 0.122 \\
\hline & $\begin{array}{l}0.1 \\
0.4 \\
2.44\end{array}$ \\
\hline
\end{tabular}




\section{THEFMOCHEM/GEO}

6

$8 A$

CONCENTFATION (FFM)

\begin{tabular}{|c|c|c|}
\hline$N A$ & & 41 \\
\hline$K$ & & 1 \\
\hline$C A$ & & 1 \\
\hline$M G$ & $<$ & 0.488 \\
\hline$F E$ & & 0.12 \\
\hline AL. & & 1.4 \\
\hline SIO2 & & 46 \\
\hline TI & 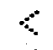 & 0.122 \\
\hline$F$ & 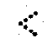 & 0.610 \\
\hline$S F i$ & & 0.04 \\
\hline $\begin{array}{l}\text { BA } \\
V\end{array}$ & 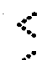 & 0.610 \\
\hline CF & 8 & 1.22 \\
\hline MN & 3 & 0.049 \\
\hline $\mathrm{CO}$ & 8 & 0.244 \\
\hline NI & 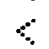 & $\begin{array}{l}0.024 \\
0.122\end{array}$ \\
\hline $\mathrm{CU}$ & $<$ & 0.061 \\
\hline MO & 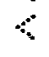 & 1.22 \\
\hline $\mathrm{FE}$ & $<$ & 0.244 \\
\hline $\mathrm{ZN}$ & $\prec$ & 0.122 \\
\hline CI & 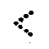 & 0.061 \\
\hline$A G$ & & 0.06 \\
\hline $\begin{array}{l}A U \\
A S\end{array}$ & 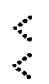 & $\begin{array}{l}0.098 \\
0.010\end{array}$ \\
\hline SE & $\therefore$ & 0.732 \\
\hline EI & $\therefore$ & 2.44 \\
\hline U & 8 & 3.10 \\
\hline TE & $\therefore$ & 1.22 \\
\hline SN & 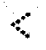 & 0.122 \\
\hline W & 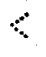 & 0.122 \\
\hline LI & $\therefore$ & 0.049 \\
\hline $\mathrm{EE}$ & $\zeta$ & $\begin{array}{l}0.005 \\
0.122\end{array}$ \\
\hline$Z F$ & 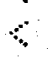 & 0.122 \\
\hline $\begin{array}{l}\text { LA } \\
E \\
T H\end{array}$ & 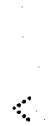 & $\begin{array}{l}0.1 \\
0.5 \\
2.44\end{array}$ \\
\hline
\end{tabular}




\section{THEFIMOCHEM 'GEO}

ELEMENT

\begin{tabular}{|c|c|c|}
\hline$N A$ & & 44 \\
\hline $\begin{array}{l}\ll \\
C A\end{array}$ & & $\begin{array}{l}1 \\
0.9\end{array}$ \\
\hline$M G$ & 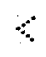 & 0.488 \\
\hline $\mathrm{FE}$ & & 0.02 \\
\hline AL. & $<$ & 0.510 \\
\hline 5102 & & 54 \\
\hline $\mathrm{TT}$ & 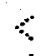 & 0.122 \\
\hline$F$ & $\lessdot$ & 0.610 \\
\hline$S F i$ & & 0.04 \\
\hline FA & ๘ & 0.610 \\
\hline$v$ & 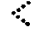 & 1.22 \\
\hline$C F:$ & $\varkappa$ & 0.049 \\
\hline MN & $\because$ & 0.244 \\
\hline $\mathrm{CO}$ & ८ & 0.024 \\
\hline$N I$ & $\zeta$ & 0.122 \\
\hline $\begin{array}{l}\mathrm{CU} \\
\mathrm{MOO}\end{array}$ & 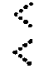 & $\begin{array}{l}0.061 \\
1.22\end{array}$ \\
\hline $\mathrm{B}$ & $\therefore$ & 0.244 \\
\hline$Z N$ & 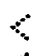 & 0.122 \\
\hline CII & 6 & 0.061 \\
\hline 46 & & 0.07 \\
\hline $\begin{array}{l}A 4 \\
A S\end{array}$ & 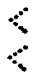 & $\begin{array}{l}0.098 \\
0.610\end{array}$ \\
\hline $5 \mathrm{E}$ & $\therefore$ & 0.732 \\
\hline 91 & $\measuredangle$ & 2.44 \\
\hline & $\zeta$ & 6.10 \\
\hline E & 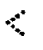 & 1.22 \\
\hline & $<$ & $\begin{array}{l}0.122 \\
0.122\end{array}$ \\
\hline$I$ & $<$ & 0.049 \\
\hline $8 E$ & $<$ & $\begin{array}{l}0.005 \\
0.122\end{array}$ \\
\hline Fi & $\therefore$ & 0.122 \\
\hline & & 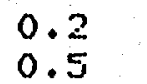 \\
\hline$H$ & 8 & 2.44 \\
\hline
\end{tabular}

\section{CONCENTFATION (FFM)}




\section{THEFMOCHEM/GEO}

$8 \quad B A$

\section{ELEMENT}

CONCENTFIATION (FPM)

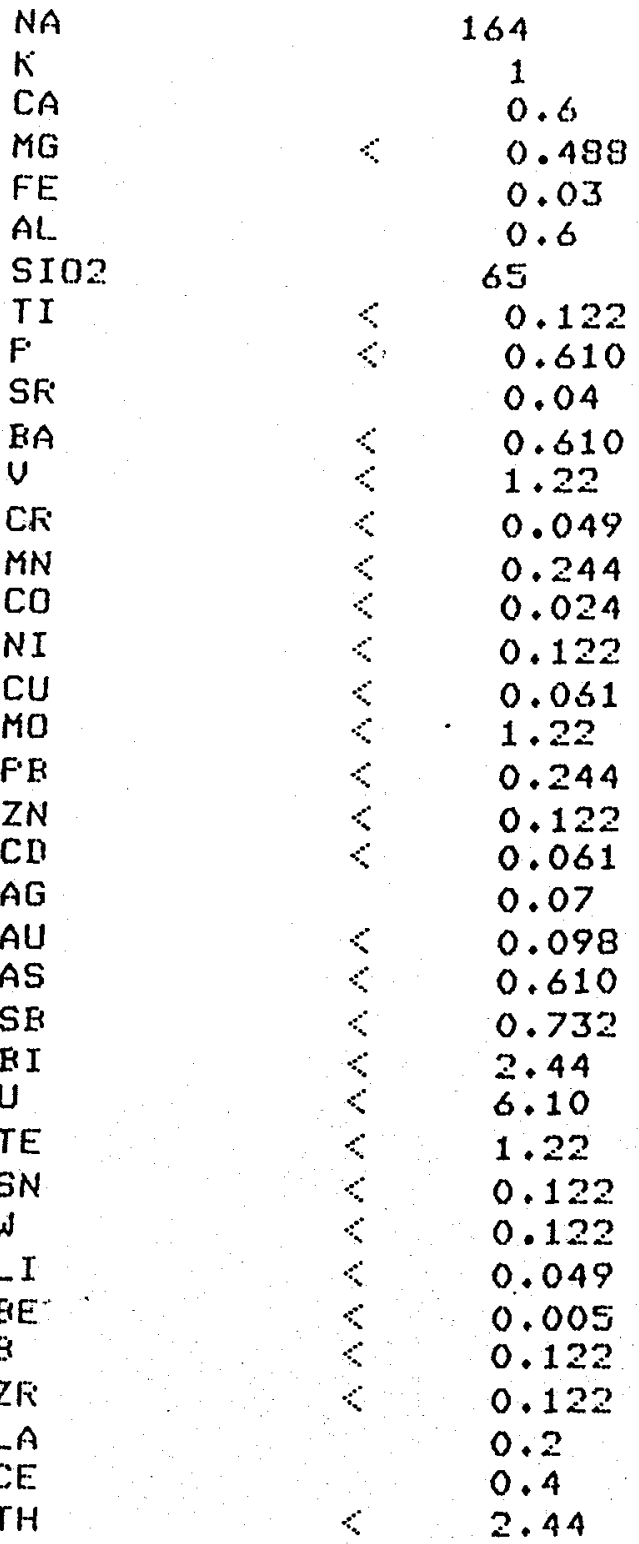




\section{THEFIMOCHEM/GED}

9

$9 A$

ELEMENT

CONCENTRATION (FFM)

NA

$K$

$C A$

$M G$

FE

AL.

SI02

TI

F.

$S F$

BA

$\checkmark$

CF

MN

CO

$\mathrm{NI}$

$\mathrm{CU}$

MO

$\mathrm{FB}$

ZN

CII

$A G$

$A U$

AS

SE

BI

U

TE

SN

W

LI

BE

E

ZF

LA

$\mathrm{TH}$

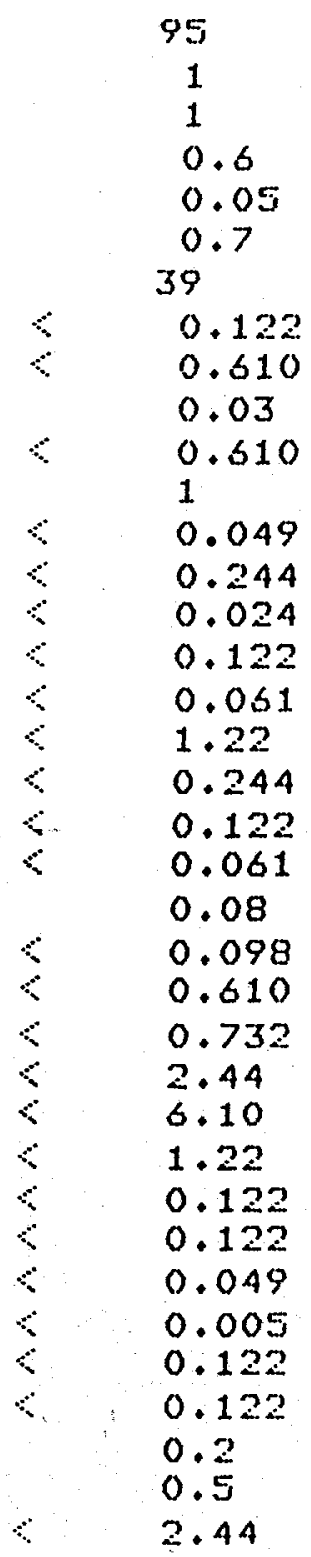


THEFMOCHEM/GEO

10

$10 \mathrm{~A}$

ELEMENT

CONCENTFATION (FFM)

NA

$K$

CA

$M G$

FE

AL

SI02

TI

$F$

SFi

BA

$\checkmark$

CF

$M N$

$\mathrm{CO}$

NI

\&. CU

FB

ZN

CII

AG

AU

AS

SB

EI

U

TE

SN

W

LI

BE

E

ZFi

LA

CE

$\mathrm{TH}$

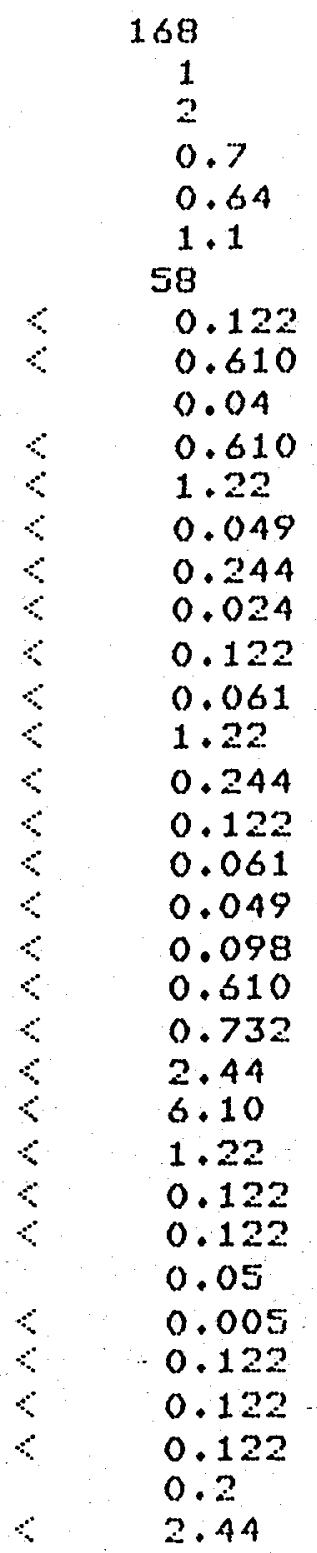




\section{THEFMOCHEM/GEO}

11. $1 \mathrm{AAFILT}$

ELEMENT

NA

Ki

CA

$M G$

FE

AL.

SIOL2

TI

F

SF

EA

U

CF:

MN

CO

$N I$

( $\mathrm{CU}$

$\mathrm{FB}$

ZN

CII

$A G$

AU

AS

SE

EI

$U$

TE

SN

W

LI

BE

E

ZF

LA

CE

TH

\section{CONCENTFATION (FFM)}

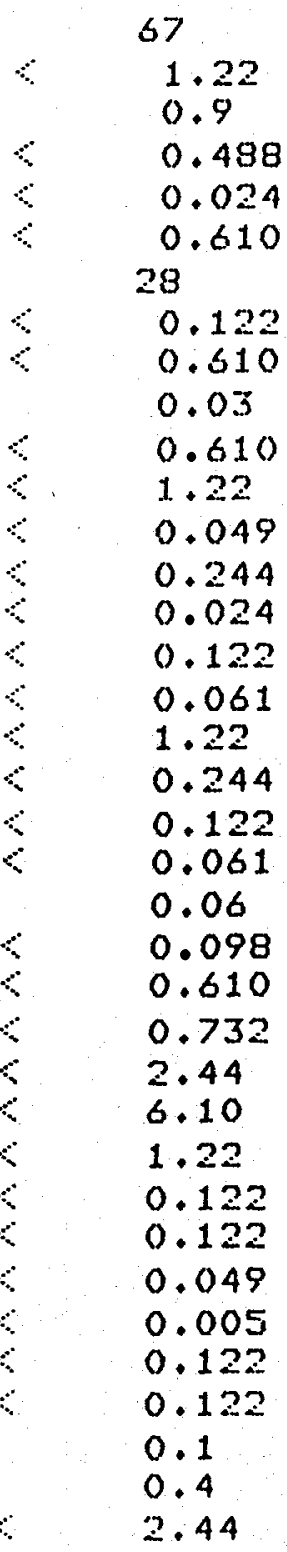




\section{THEFMOCHEM/GEO}

12. 11A UNFILT

\section{ELEMENT}

\section{CONCENTFATION (FFM)}

NA

Ki

$\mathrm{CA}$

$M G$

FE

$\mathrm{AL}$

SIO2

TI

$\mathrm{F}$

SF

BA

$\checkmark$

CF

$M N$

$\mathrm{CO}$

NI

$\left(\begin{array}{ll}\mathrm{CU} \\ \mathrm{MO}\end{array}\right.$

$F E$

ZN

$C \Pi$

AG

$A U$

AS

SE

BI

$U$

TE

SN

W

LI

EIE

E

ZFi

LA

CE

$\mathrm{TH}$

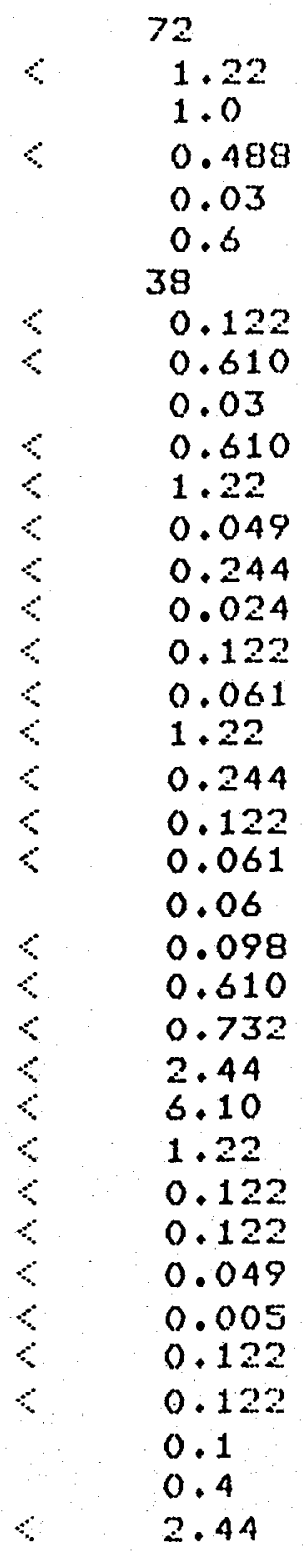




\section{THEFMOCHEM/GEO}

13 $12 \mathrm{~A}$

ELEMENT

CONCENTRATION (FFM)

\begin{tabular}{|c|c|c|}
\hline NA & & 66 \\
\hline $\begin{array}{l}\kappa \\
C A\end{array}$ & 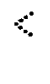 & $\begin{array}{l}1.22 \\
0.5\end{array}$ \\
\hline MG & 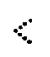 & 0.488 \\
\hline$F E$ & 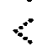 & 0.024 \\
\hline$A L$ & $<$ & 0.610 \\
\hline SIO2 & & 28 \\
\hline$T I$ & $<$ & 0.122 \\
\hline$F^{\prime}$ & $<$ & 0.610 \\
\hline SFi & & 0.01 \\
\hline$B A$ & $\therefore$ & 0.610 \\
\hline$v$ & 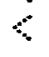 & 1.22 \\
\hline CFi & $\because$ & 0.049 \\
\hline$M N$ & 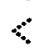 & 0.244 \\
\hline $\mathrm{CO}$ & $\measuredangle$ & 0.024 \\
\hline$N I$ & $\measuredangle$ & 0.122 \\
\hline $\mathrm{Cu}$ & $\therefore$ & 0.061 \\
\hline MO & $<$ & 1.22 \\
\hline$F E$ & $<$ & 0.244 \\
\hline$Z N$ & $<$ & 0.122 \\
\hline $\mathrm{Cn}$ & $<$ & 0.061 \\
\hline$A G$ & & 0.05 \\
\hline$A U$ & $<$ & 0.098 \\
\hline AS & $<$ & 0.610 \\
\hline SE & $<$ & 0.732 \\
\hline EI & $<$ & 2.44 \\
\hline $\mathrm{U}$ & $<$ & 6.10 \\
\hline TE & $<$ & 1.22 \\
\hline $\begin{array}{l}\text { SN } \\
W\end{array}$ & 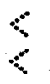 & $\begin{array}{l}0.122 \\
0.122\end{array}$ \\
\hline LI & $<$ & 0.049 \\
\hline $\begin{array}{l}\mathrm{BE} \\
\mathrm{E}\end{array}$ & $<$ & $\begin{array}{l}0.005 \\
0.122\end{array}$ \\
\hline$Z F$ & 8 & $\begin{array}{l}0.122 \\
0.122\end{array}$ \\
\hline $\begin{array}{l}\text { LA } \\
C E\end{array}$ & $<$ & $\begin{array}{l}0.122 \\
0.4\end{array}$ \\
\hline $\mathrm{TH}$ & $<$ & 2.44 \\
\hline
\end{tabular}




\section{THEFMOCHEM/GEO}

$14 \quad 13 \mathrm{~A}$

ELEMENT

\begin{tabular}{|c|c|c|}
\hline NA & & 69 \\
\hline $\begin{array}{l}K \\
C A\end{array}$ & 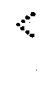 & $\frac{1.22}{0.5}$ \\
\hline$M G$ & 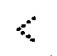 & 0.488 \\
\hline$F E$ & $\checkmark$ & 0.024 \\
\hline$A L$ & 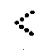 & 0.610 \\
\hline SIOZ & & 28 \\
\hline TI & $\because$ & 0.122 \\
\hline$F$ & $\ddots$ & 0.610 \\
\hline SF & & 0.01 \\
\hline $\begin{array}{l}E A \\
U\end{array}$ & $<$ & $\begin{array}{l}0.310 \\
1.22\end{array}$ \\
\hline$C F$ & $<$ & 0.049 \\
\hline$M N$ & $<$ & 0.244 \\
\hline $\mathrm{CO}$ & 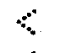 & 0.024 \\
\hline$N I$ & $<$ & 0.122 \\
\hline 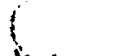 & $\zeta$ & 0.061 \\
\hline inu & 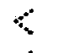 & 1.22 \\
\hline $\mathrm{FE}$ & $<$ & 0.244 \\
\hline $\begin{array}{l}Z N \\
\mathrm{CI}\end{array}$ & $<$ & $\begin{array}{l}0.122 \\
0.061\end{array}$ \\
\hline$A G$ & & 0.05 \\
\hline$A U$ & $\zeta$ & 0.098 \\
\hline AS & $\lessdot$ & 0.610 \\
\hline$S E$ & $\diamond$ & 0.732 \\
\hline$E I$ & $\because$ & 2.44 \\
\hline$U$ & $<$ & 6.10 \\
\hline TE & $<$ & 1.22 \\
\hline SN & $\therefore$ & 0.122 \\
\hline$W$ & 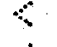 & 0.122 \\
\hline LI & 3 & 0.049 \\
\hline $\mathrm{BE}$ & $\vdots$ & 0.005 \\
\hline$E$ & $\because$ & 0.122 \\
\hline$Z F$ & $\measuredangle$ & 0.122 \\
\hline LE & 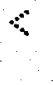 & $\begin{array}{l}0.122 \\
0.4\end{array}$ \\
\hline TH & $\because$ & 2.44 \\
\hline
\end{tabular}


THERMOCHEM/GEO

$15 \quad 14 \mathrm{~A}$

ELEMENT

NA

$K$

CA

$M G$

FE

$A L$

SIO2

TI

$F$

SF

EA

$\checkmark$

CFi

$M N$

CO

NI

$\mathrm{CU}$

MO

F.E

ZN

CD

$A G$

$A U$

AS

SE

BI

U

TE

SN

W

LI

EE

E

ZFi

LA

CE

$\mathrm{TH}$
CONCENTFIATION (FFM)

$\begin{array}{ll} & 68 \\ & 1.22 \\ & 0.6 \\ < & 0.488 \\ < & 0.024 \\ & 0.610\end{array}$

33

0.122
$0 \quad 0.610$

0.01

0.610

1.22

0.049

0.244

0.024

0.122

0.061

1.22

0.244

0.122

0.061

0.06

0.098

0.610

0.732

2.44

6.10

1.22

0.122

0.122

0.049

0.005

0.122

0.122

0.1

0.4

2.44 


\section{THEFMOCHEM/GEO}

16

ELEMENT

NA

K

$M G$

FE

AL.

SIO2

TI

$F$

SF

BA

$\checkmark$

CF

MiN

CO

NI

$\mathrm{CU}$

MO

$F E$

ZN

CI

$A G$

AU

AS

SB

EI

$U$

TE

SN

w

LI

BE

I

ZFi

LA

CE

TH
CONCENTRATION (FFM)

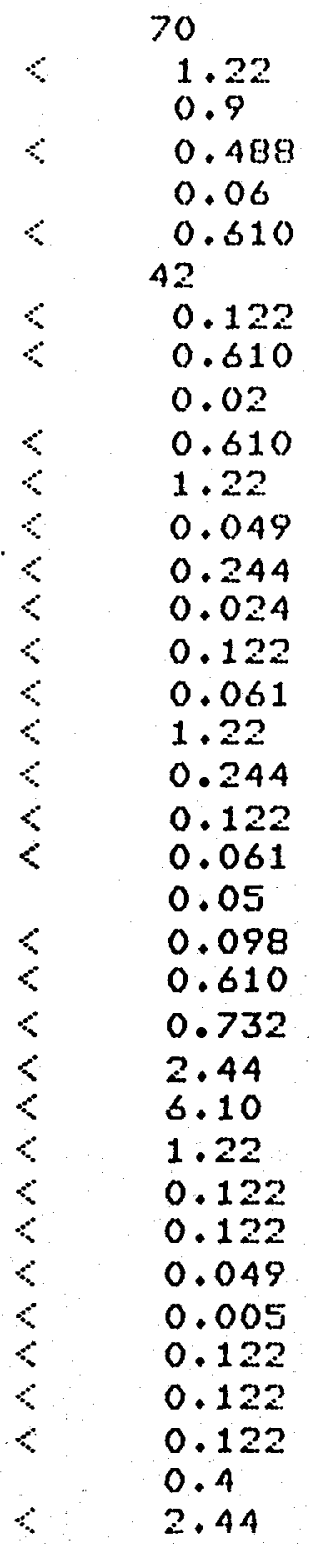


THEFMOCHEM/GEO

$17 \quad 16 \mathrm{~A}$

ELEMENT

\begin{tabular}{|c|c|c|}
\hline$N A$ & & 98 \\
\hline $\begin{array}{l}\stackrel{K}{C} \\
C A\end{array}$ & 6 & $\begin{array}{l}1.22 \\
0.6\end{array}$ \\
\hline$M G$ & $\measuredangle$ & 0.488 \\
\hline$F E$ & 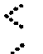 & 0.024 \\
\hline$A L$ & $<$ & 0.610 \\
\hline S102 & & 42 \\
\hline$T I$ & 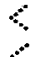 & 0.122 \\
\hline $\begin{array}{l}F \\
S F\end{array}$ & & $\begin{array}{l}0.610 \\
0.02\end{array}$ \\
\hline $\begin{array}{l}\text { SFi } \\
\text { BA }\end{array}$ & & 0.02 \\
\hline $\mathrm{E}^{\mathrm{BA}}$ & 3 & $\begin{array}{l}0.310 \\
1.22\end{array}$ \\
\hline CFi & $\therefore$ & 0.049 \\
\hline$M N$ & 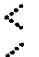 & 0.244 \\
\hline $\mathrm{CO}$ & $\measuredangle$ & 0.024 \\
\hline$N I$ & 6 & 0.122 \\
\hline $\mathrm{CU}$ & $\therefore$ & 0.061 \\
\hline MO & ৫ & 1.22 \\
\hline$F \cdot H$ & $<$ & 0.244 \\
\hline $\begin{array}{l}Z N \\
\mathrm{CI}\end{array}$ & $<$ & $\begin{array}{l}0.122 \\
0.061\end{array}$ \\
\hline$A G$ & $<$ & 0.049 \\
\hline AU & $<$ & 0.098 \\
\hline AS & $<$ & 0.610 \\
\hline SE & $\therefore$ & 0.732 \\
\hline BI & $\therefore$ & 2.44 \\
\hline U & $<$ & 6.10 \\
\hline TE & $<$ & 1.22 \\
\hline $\begin{array}{l}S N \\
W\end{array}$ & $\because$ & $\begin{array}{l}0.122 \\
0.122\end{array}$ \\
\hline$L I$ & $<$ & 0.049 \\
\hline $\begin{array}{l}E E \\
E\end{array}$ & $<$ & $\begin{array}{l}0.005 \\
0.122\end{array}$ \\
\hline$Z F i$ & 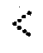 & 0.122 \\
\hline$L A$ & $\measuredangle$ & 0.122 \\
\hline $\begin{array}{l}\text { LE } \\
\text { TH }\end{array}$ & 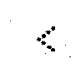 & \\
\hline
\end{tabular}

CONCENTRATION (FFM)

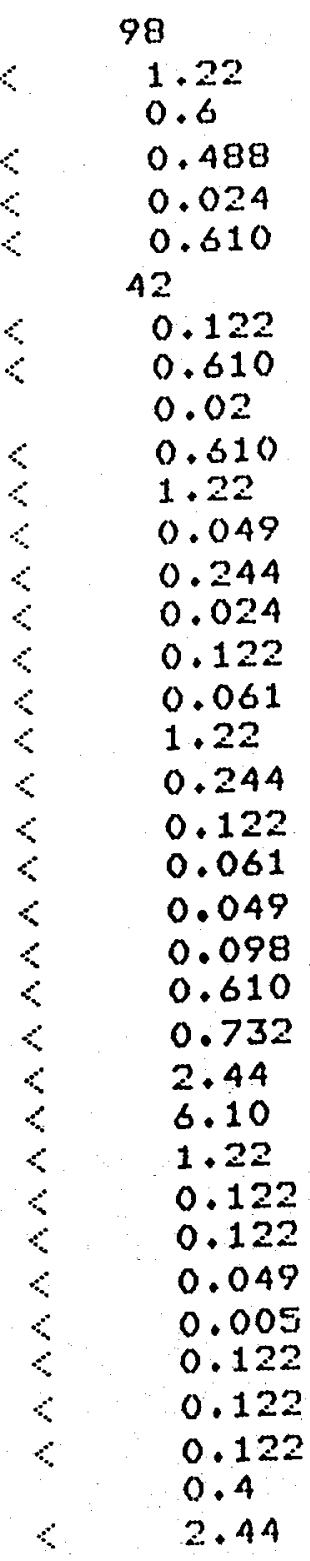


THEFMOCHEM/GEO

18 $17 A$

ELEMENT

CONCENTFATION (FFM)

$N A$

$K$

$C A$

$M G$

FE

$A L$

SI02

rI

$F$

SF

EA

U

CR

MN

CO

NI

(. CU

MO

$\mathrm{F} E$

ZN

$C$ II

$A G$

$A U$

AS

SE

BI

$u$

TE

SN

W

LI

BE

E

- $Z F$

LA

CE

TH

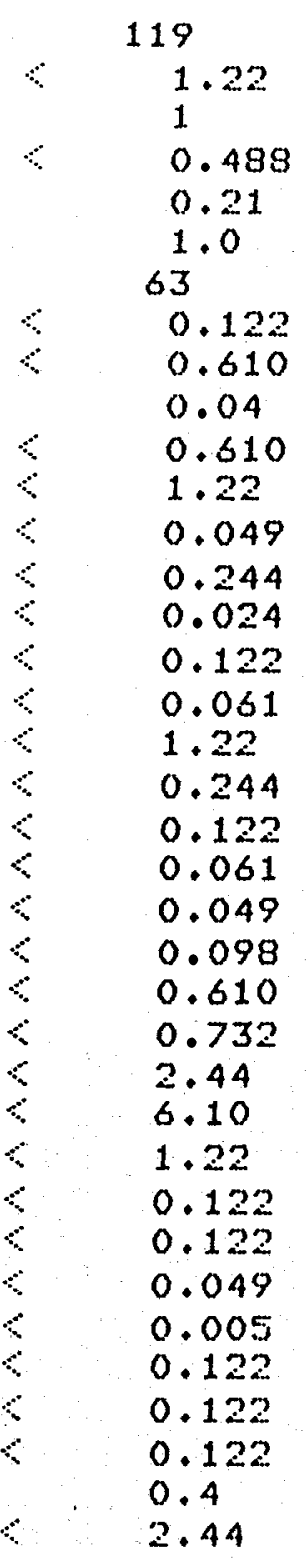




\section{THEFMOCHEM/GEO}

$187 \quad 18 A$

ELEMENT

CONCENTFATION (FFM)

NA

ii

$C A$

$M G$

FE

AL

SIO2

TI

F

SF

BA

$\checkmark$

CF

$M N$

CO

NI

CU

MO

$F B$

$Z N$

CII

AG

AU

AS

SE

BI

$u$

TE

SN

$W$

LI

RE

E

ZFi

$L A$

CE

$\mathrm{TH}$

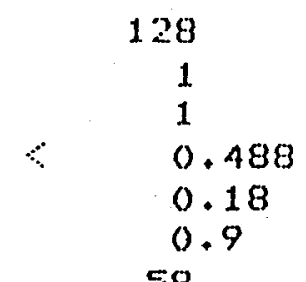

59
$<\quad 0.122$
0.610

0.04

$\therefore \quad 0.610$

$\therefore \quad 1.22$

$\therefore \quad 0.049$

$\therefore \quad 0.244$

$\because \quad 0.024$

$<\quad 0.122$

$0 \quad 0.061$

$\therefore \quad 1.22$

$<\quad 0.244$

$<\quad 0.122$

$<\quad 0.061$

$<\quad 0.049$

○ 0.098

$\div \quad 0.510$

$\therefore \quad 0.732$

$3 \quad 2.44$

$6 \quad 6.10$

$\div \quad 1.22$

$\therefore \quad 0.122$

$\because \quad 0.122$

$8 \quad 0.049$

$<\quad 0.005$

$8 \quad 0.122$

$\therefore \quad 0.122$

$<\quad 0.122$

0.3

$6 \quad 2.44$ 


\section{THERMOCHEM/GEO}

20

$19 \mathrm{~A}$

ELEMENT

CONCENTFATION (FFM)

\begin{tabular}{|c|c|c|}
\hline$N A$ & & 91. \\
\hline $\begin{array}{l}K \\
C A\end{array}$ & $\therefore$ & $\begin{array}{l}1.22 \\
0.9\end{array}$ \\
\hline$M G$ & $\lessdot$ & 0.488 \\
\hline$F E$ & & 0.03 \\
\hline$A L$ & $\therefore$ & 0.610 \\
\hline SIO2 & & 43 \\
\hline$T I$ & 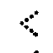 & 0.122 \\
\hline$F$ & 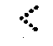 & 0.610 \\
\hline SF: & & 0.03 \\
\hline $\begin{array}{l}E A \\
v\end{array}$ & $\measuredangle$ & $\begin{array}{l}0.610 \\
1.22\end{array}$ \\
\hline CFi & $\ddots$ & 0.049 \\
\hline$M N$ & 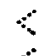 & 0.244 \\
\hline $\mathrm{CO}$ & ๘ & 0.024 \\
\hline$N I$ & $\ddots$ & 0.122 \\
\hline $\mathrm{CU}$ & $\measuredangle$ & 0.061 \\
\hline MO & 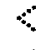 & 1.22 \\
\hline$F^{\prime} B$ & $<$ & 0.244 \\
\hline $\begin{array}{l}Z N \\
C I\end{array}$ & $<$ & $\begin{array}{l}0.122 \\
0.061\end{array}$ \\
\hline$A G$ & $<$ & 0.049 \\
\hline $\mathrm{AU}$ & $<$ & 0.098 \\
\hline AS & $<$ & 0.610 \\
\hline SE & $<$ & 0.732 \\
\hline EI & $\because$ & 2.44 \\
\hline $\mathbf{U}$ & $<$ & 6.10 \\
\hline TE & $\therefore$ & 1.22 \\
\hline${ }_{W}^{S N}$ & $<$ & $\begin{array}{l}0.122 \\
0.122\end{array}$ \\
\hline L.I & $<$ & 0.049 \\
\hline $\mathrm{EE}$ & 6 & 0.005 \\
\hline E & 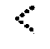 & 0.122 \\
\hline$Z F$ & $\measuredangle$ & 0.122 \\
\hline LA & 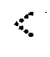 & 0.122 \\
\hline$C E$ & & 0.3 \\
\hline TH & ๘ & 2.44 \\
\hline
\end{tabular}




\section{THEFMOCHEM/GEO}

21

$20 \mathrm{~A}$

ELEMENT

CONCENTFATION (FFM)

NA

$K$

$C A$

$M G$

FE

AL.

SI02

TI

F

$S F$

EA

$\checkmark$

CF:

MN

CO

$N I$

$\mathrm{CU}$

$\mathrm{MO}$

$F \cdot B$

ZN

CII

AG

AU

AS

SE

EII

$U$

TE

SN

W

LI

EE.

$\mathrm{B}$

ZFi

LA

CE

TH

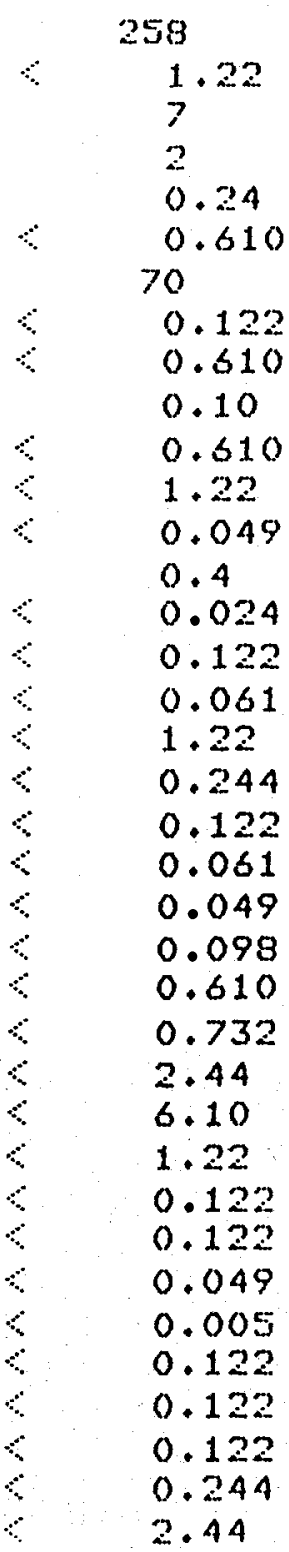




\section{THEFMOCHEM/GEO}

$22 \quad 21 \mathrm{~A}$

\section{ELEMENT}

CONCENTFIATION (FFM)

\begin{tabular}{|c|c|c|}
\hline$N A$ & & 118 \\
\hline $\begin{array}{l}K \\
C A\end{array}$ & $\measuredangle$ & $\begin{array}{l}1.22 \\
1\end{array}$ \\
\hline$M G$ & $<$ & 0.488 \\
\hline$F E$ & & 0.49 \\
\hline$A L$ & & 0.9 \\
\hline SIOZ & & 53 \\
\hline TI & 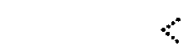 & 0.122 \\
\hline$F$ & 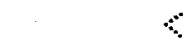 & 0.610 \\
\hline SF: & & 0.02 \\
\hline EA & 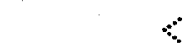 & 0.510 \\
\hline v & $\lessdot$ & 1.22 \\
\hline CFi: & $\because$ & 0.049 \\
\hline$M N$ & 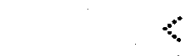 & 0.244 \\
\hline $\mathrm{CO}$ & $\measuredangle$ & 0.024 \\
\hline$N I$ & $<$ & 0.122 \\
\hline Co: & 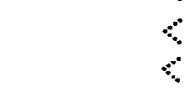 & $\begin{array}{l}0.061 \\
1.22\end{array}$ \\
\hline$F \cdot B$ & $\varsigma$ & 0.244 \\
\hline $\begin{array}{l}Z N \\
C I I\end{array}$ & - & $\begin{array}{l}0.2 \\
0.061\end{array}$ \\
\hline$A G$ & $\therefore$ & 0.049 \\
\hline $\begin{array}{l}A U \\
A S\end{array}$ & $<$ & $\begin{array}{l}0.098 \\
0.610\end{array}$ \\
\hline SB & 8 & 0.732 \\
\hline$E I$ & $<$ & 2.44 \\
\hline$U$ & $\because$ & 3.10 \\
\hline TE & $\therefore$ & 1.22 \\
\hline$S N$ & $<$ & 0.122 \\
\hline$\omega$ & 6 & 0.122 \\
\hline LI & 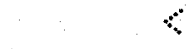 & 0.049 \\
\hline$B E$ & 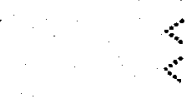 & $\begin{array}{l}0.005 \\
0.122\end{array}$ \\
\hline & 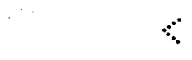 & 0.122 \\
\hline-5 & $<$ & $\begin{array}{l}0.122 \\
0.3\end{array}$ \\
\hline $\mathrm{rH}$ & $\because$ & 2.44 \\
\hline
\end{tabular}




\section{THERMOCHEM/GEO}

$23 \quad 22 A$

ELEMENT CONCENTFATION (FFM)

\begin{tabular}{|c|c|c|}
\hline$N A$ & & 16 \\
\hline $\begin{array}{l}K \\
C A\end{array}$ & $\because$ & $\begin{array}{l}1.22 \\
0.9\end{array}$ \\
\hline$M G$ & $\therefore$ & 0.488 \\
\hline$F E$ & & 0.09 \\
\hline AL & & 0.7 \\
\hline 5102 & & 57 \\
\hline $\mathrm{TI}$ & $\therefore$ & 0.122 \\
\hline$F$ & $\measuredangle$ & 0.610 \\
\hline SFi & & 0.02 \\
\hline $\begin{array}{l}F A \\
U\end{array}$ & 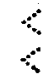 & $\begin{array}{l}0.610 \\
1.22\end{array}$ \\
\hline CFi & $<$ & 0.049 \\
\hline $\begin{array}{l}\mathrm{MN} \\
\mathrm{CO}\end{array}$ & 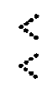 & $\begin{array}{l}0.244 \\
0.024\end{array}$ \\
\hline$N I$ & 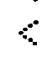 & 0.122 \\
\hline CU & 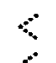 & 0.061 \\
\hline MO & $\because$ & 1.22 \\
\hline$F^{\prime} E$ & $\therefore$ & 0.244 \\
\hline$Z N$ & $\therefore$ & 0.122 \\
\hline CII & 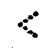 & 0.061 \\
\hline$A G$ & $<$ & 0.049 \\
\hline AU & $\therefore$ & 0.098 \\
\hline$A S$ & $\therefore$ & 0.610 \\
\hline SE & $<$ & 0.732 \\
\hline EI & 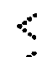 & 2.44 \\
\hline$u$ & $<$ & 6.10 \\
\hline TE & $\measuredangle$ & 1.22 \\
\hline $\begin{array}{l}\text { SN } \\
W\end{array}$ & $<$ & $\begin{array}{l}0.122 \\
0.122\end{array}$ \\
\hline LI & $\because$ & 0.049 \\
\hline $\begin{array}{l}\mathrm{BE} \\
\mathrm{H}\end{array}$ & $\zeta$ & $\begin{array}{l}0.005 \\
0.122\end{array}$ \\
\hline$Z F$ & $<$ & 0.122 \\
\hline $\begin{array}{l}\text { LA } \\
C E\end{array}$ & 6 & $\begin{array}{l}0.122 \\
0.3\end{array}$ \\
\hline $\mathrm{TH}$ & ๘ & 2.44 \\
\hline
\end{tabular}




\section{THEFMOCHEM/GEO}

$24 \quad 23 A$

ELEMENT

CONCENTFIATION (FFM)

$N A$

$K$

$C A$

$M G$

FE

AL.

SI02

TI

F.

SF

EA

$\checkmark$

CF:

MN

CO

- NI

CU

MO

$F \cdot E$

ZN

$\mathrm{CII}$

AG

AU

AS

SB

BI

UE

SN

W

LI

BE

E

ZFi

LA

CE

TH

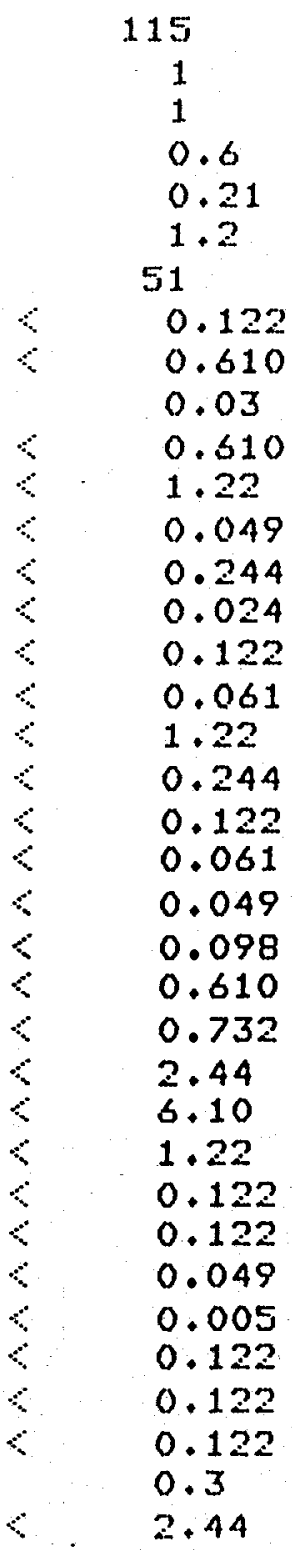




\section{THEFMOCHEM/GEO}

$25 \quad 24 A$

\section{ELEMENT}

CONCENTFATION (FFM)

\begin{tabular}{|c|c|c|}
\hline$N A$ & & 37 \\
\hline$\kappa$ & & 1 \\
\hline$C A$ & & 1 \\
\hline$M G$ & 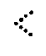 & 0.488 \\
\hline$F E$ & & 0.14 \\
\hline AL. & & 1.0 \\
\hline SI02 & & 63 \\
\hline T.I & $<$ & 0.122 \\
\hline $\mathrm{F}$ & 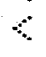 & 0.510 \\
\hline SFi & & 0.03 \\
\hline $\mathrm{FA}$ & 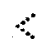 & 0.610 \\
\hline$v$ & 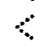 & 1.22 \\
\hline CF & $\ddots$ & 0.049 \\
\hline$M N$ & $<$ & 0.244 \\
\hline $\mathrm{CO}$ & 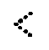 & 0.024 \\
\hline$N I$ & $<$ & 0.122 \\
\hline $\mathrm{Cu}$ & $<$ & 0.061 \\
\hline MO & $<$ & 1.22 \\
\hline$F B$ & 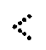 & 0.244 \\
\hline$Z N$ & $<$ & 0.122 \\
\hline CI & $<$ & 0.061 \\
\hline$A G$ & $<$ & 0.049 \\
\hline $\mathrm{AU}$ & $<$ & 0.098 \\
\hline AS & 6 & 0.610 \\
\hline SE & $<$ & 0.732 \\
\hline EI & 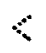 & 2.44 \\
\hline$U$ & $<$ & 6.10 \\
\hline TE & $<$ & 1.22 \\
\hline $\begin{array}{l}S N \\
W\end{array}$ & $<$ & $\begin{array}{l}0.122 \\
0.122\end{array}$ \\
\hline$L I$ & ๘ & 0.049 \\
\hline HE & $\ddots$ & 0.005 \\
\hline $\begin{array}{l}\mathrm{H} \\
Z F\end{array}$ & 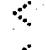 & 0.122 \\
\hline$Z F$ & $<$ & 0.122 \\
\hline $\begin{array}{l}\text { LA } \\
C E\end{array}$ & $\lessdot$ & $\begin{array}{l}0.122 \\
0.3\end{array}$ \\
\hline $\mathrm{TH}$ & $<$ & 2.44 \\
\hline
\end{tabular}




\section{THEFMOCHEM/GEO}

$26 \quad 25 A$

ELEMENT

$N A$

$K$

$\mathrm{CA}$

$M G$

$F E$

AL.

SIO2

TI

$F$

$S F$

EA

U

CF:

$M N$

CO

NI

MO

$F \cdot B$

ZN

$C D$

AG

AU

AS

SE

BI

$U$

TE

SN

W

LI

BE

B

ZFi

LA

CE

TH

\section{CONCENTFIATION (FFM)}

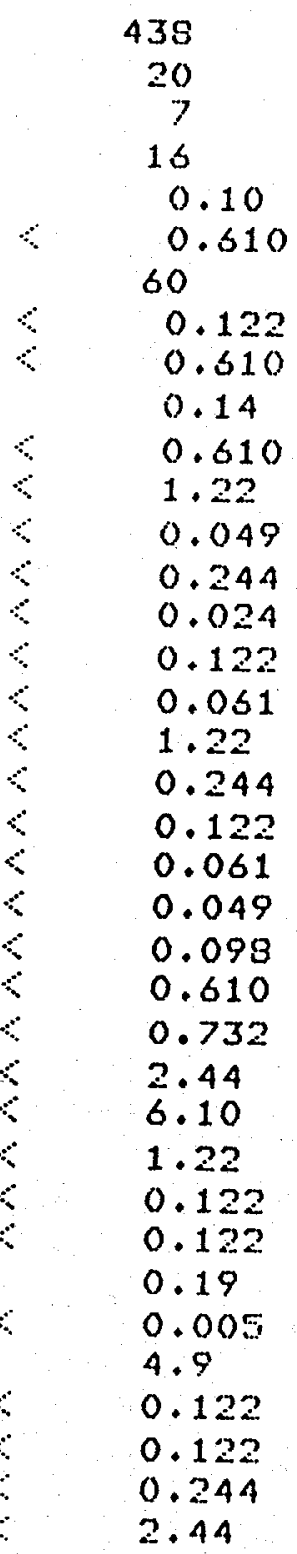




\section{THEFMOCHEM/GEO}

$27 \quad 26 A$

ELEMENT

NA

$K$

CA

$M G$

FE

AL

SI02

TI

$F$

SFi

BA

V

CFi

MN

CO

NI

$\mathrm{CU}$

MO

$F \cdot B$

ZN

CII

$A G$

$A U$

AS

SE

BI

U

TE

SN

W

LI

BE

B

$Z F$

$L A$

CE

$\mathrm{TH}$
CONCENTFATION (FFM)

\begin{tabular}{|c|}
\hline 27 \\
\hline 1 \\
\hline 1 \\
\hline 0.488 \\
\hline 0.05 \\
\hline 0.610 \\
\hline 41 \\
\hline 0.120 \\
\hline 0.610 \\
\hline 0.04 \\
\hline 0.610 \\
\hline 1.22 \\
\hline 0.049 \\
\hline 0.244 \\
\hline 0.024 \\
\hline 0.122 \\
\hline 0.061 \\
\hline 1.22 \\
\hline 0.244 \\
\hline 0.122 \\
\hline 0.061 \\
\hline 0.049 \\
\hline 0.098 \\
\hline 0.610 \\
\hline 0.732 \\
\hline 2.44 \\
\hline 3.10 \\
\hline 1.22 \\
\hline 0.122 \\
\hline 0.122 \\
\hline 0.049 \\
\hline $\begin{array}{l}0.005 \\
0.3\end{array}$ \\
\hline 0.122 \\
\hline $\begin{array}{l}0.122 \\
0.3\end{array}$ \\
\hline $2.4 A$ \\
\hline
\end{tabular}




\section{THEFMOCHEM/GEO}

28

$27 A$

\section{ELEMENT}

CONCENTFATION (FFM)

NA

K

$C A$

$M G$

FE

AL.

SI02

TI

F.

SFi

BA

$\checkmark$

CF:

$\mathrm{MN}$

CO

NI

$\mathrm{CU}$

MO

$F E$

ZN

CII

AG

AU

AS

SB

BI

$U$

TE

SN

W

LI

HE

B

ZFi

LA

CE

$\mathrm{TH}$

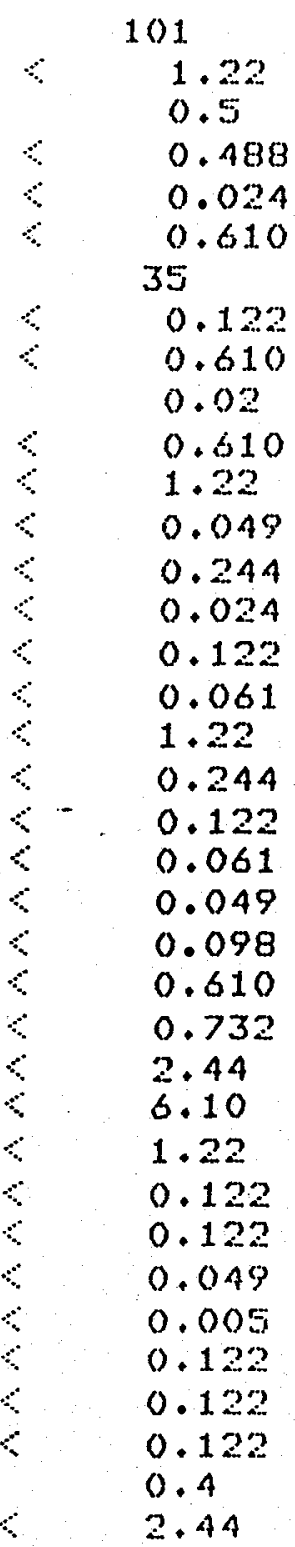


THEFMOCHEM/GEO

$29 \quad 28 \mathrm{~A}$

ELEMENT

CONCENTFATION (FFM)

\begin{tabular}{|c|c|c|}
\hline$N A$ & & 112 \\
\hline Ki & & 2 \\
\hline$C A$ & & 1 \\
\hline$M G$ & & 0.5 \\
\hline$F E$ & & 0.08 \\
\hline Al. & & 0.9 \\
\hline 5102 & & 53 \\
\hline TI & $<$ & 0.122 \\
\hline$F$ & 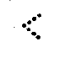 & 0.310 \\
\hline$S F$ & & 0.04 \\
\hline $\begin{array}{l}B A \\
U\end{array}$ & $\because$ & $\begin{array}{l}0.610 \\
1\end{array}$ \\
\hline CFi & 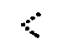 & 0.049 \\
\hline$M N$ & $\because$ & 0.244 \\
\hline $\mathrm{CO}$ & $\therefore$ & 0.024 \\
\hline NI & $\measuredangle$ & 0.122 \\
\hline $\mathrm{CU}$ & 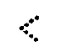 & 0.051 \\
\hline MO & $\zeta$ & 1.22 \\
\hline $\mathrm{FB}$ & 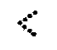 & 0.244 \\
\hline $\begin{array}{l}Z N \\
C D\end{array}$ & $<$ & $\begin{array}{l}0.122 \\
0.061\end{array}$ \\
\hline$A G$ & & 0.08 \\
\hline $\begin{array}{l}\text { AU } \\
\text { AS }\end{array}$ & 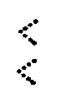 & $\begin{array}{l}0.098 \\
0.610\end{array}$ \\
\hline$S E$ & $<$ & 0.732 \\
\hline BI & $\lessdot$ & 2.44 \\
\hline$U$ & 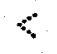 & 6.10 \\
\hline TE & $<$ & 1.22 \\
\hline $\begin{array}{l}S N \\
W\end{array}$ & $<$ & $\begin{array}{l}0.122 \\
0.122\end{array}$ \\
\hline LI & & 0.05 \\
\hline $8 E$ & $\therefore$ & 0.005 \\
\hline $\mathrm{E}$ & $\therefore$ & 0.122 \\
\hline$Z F$ & 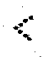 & 0.122 \\
\hline $\begin{array}{l}\text { LA } \\
C E\end{array}$ & & $\begin{array}{l}0.2 \\
0.6\end{array}$ \\
\hline $\mathrm{TH}$ & $\therefore$ & 2.44 \\
\hline
\end{tabular}




\section{THEFMOCHEM/GEO}

30

$29 A$

ELEMENT

CONCENTFATION (FFM)

\begin{tabular}{|c|c|c|}
\hline$N A$ & & 20 \\
\hline$K$ & & 3 \\
\hline$C A$ & & 29 \\
\hline$M G$ & & 7 \\
\hline$F E$ & & 5.79 \\
\hline AL & ૪ & 0.310 \\
\hline SI0? & & 04 \\
\hline$T I$ & $\measuredangle$ & 0.122 \\
\hline$F^{\prime}$ & $\varkappa$ & 0.610 \\
\hline$S F$ & & 0.41 \\
\hline$E A$ & & 0.9 \\
\hline U & $<$ & 1.22 \\
\hline CFi & $<$ & 0.049 \\
\hline $\begin{array}{l}M N \\
C O\end{array}$ & $\because$ & $\begin{array}{l}0.8 \\
0.024\end{array}$ \\
\hline$N I$ & 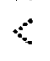 & 0.122 \\
\hline $\begin{array}{l}\mathrm{CU} \\
\mathrm{MO}\end{array}$ & 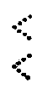 & $\begin{array}{l}0.061 \\
1.22\end{array}$ \\
\hline $\mathrm{PE}$ & $\therefore$ & 0.244 \\
\hline $\begin{array}{l}Z N \\
C D\end{array}$ & $<$ & $\begin{array}{l}1.1 \\
0.061\end{array}$ \\
\hline$A G$ & $<$ & 0.049 \\
\hline AU & $<$ & 0.098 \\
\hline$A S$ & 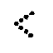 & 0.610 \\
\hline SB & $\because$ & 0.732 \\
\hline BI & $\therefore$ & 2.44 \\
\hline$U$ & 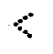 & 3.10 \\
\hline TE & $\therefore$ & 1.22 \\
\hline SN & $\measuredangle$ & $\begin{array}{l}0.122 \\
0.122\end{array}$ \\
\hline$L I$ & & 0.07 \\
\hline$\frac{\mathrm{BE}}{\mathrm{B}}$ & 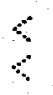 & $\begin{array}{l}0.005 \\
0.122\end{array}$ \\
\hline$Z F$ & $\measuredangle$ & 0.122 \\
\hline $\operatorname{LA}$ & $\therefore$ & 0.122 \\
\hline$C E$ & $\because$ & 0.244 \\
\hline TH & 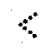 & 2.44 \\
\hline
\end{tabular}




\section{THEFMOCHEM/GEO}

$3130 \mathrm{~A}$

\begin{tabular}{|c|c|c|}
\hline$N A$ & \multicolumn{2}{|c|}{207} \\
\hline $\begin{array}{l}K \\
C A\end{array}$ & $<$ & $\frac{1.22}{3}$ \\
\hline MG & & 1 \\
\hline$F E$ & & 0.75 \\
\hline AL & & 1.5 \\
\hline SI02 & & 91 \\
\hline $\begin{array}{l}T I \\
F\end{array}$ & $<$ & $\begin{array}{l}0.122 \\
0.610\end{array}$ \\
\hline$S F$ & & 0.09 \\
\hline $\begin{array}{l}B A \\
U\end{array}$ & 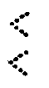 & $\begin{array}{l}0.610 \\
1.22\end{array}$ \\
\hline CFi & $\therefore$ & 0.049 \\
\hline $\begin{array}{l}\mathrm{MN} \\
\mathrm{CO}\end{array}$ & $<$ & $\begin{array}{l}0.244 \\
0.024\end{array}$ \\
\hline$N I$ & $\therefore$ & 0.122 \\
\hline $\begin{array}{l}C U \\
M O\end{array}$ & $\measuredangle$ & $\begin{array}{l}0.061 \\
1.22\end{array}$ \\
\hline$F \cdot E$ & $<$ & 0.244 \\
\hline $\begin{array}{l}Z N \\
C n\end{array}$ & 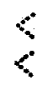 & $\begin{array}{l}0.122 \\
0.061\end{array}$ \\
\hline$A G$ & $\therefore$ & 0.049 \\
\hline $\begin{array}{l}\text { AU } \\
\text { AS }\end{array}$ & $<$ & $\begin{array}{l}0.098 \\
0.610\end{array}$ \\
\hline SE & $<$ & 0.732 \\
\hline $\begin{array}{l}\mathrm{RI} \\
U\end{array}$ & $<$ & $\begin{array}{l}2.44 \\
6.10\end{array}$ \\
\hline TE & $<$ & 1.22 \\
\hline $\begin{array}{l}S N \\
W\end{array}$ & 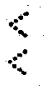 & $\begin{array}{l}0.122 \\
0.122\end{array}$ \\
\hline LI & $\therefore$ & 0.049 \\
\hline $\begin{array}{l}B E \\
F\end{array}$ & $\vdots$ & 0.005 \\
\hline $\mathrm{ZFi}$ & 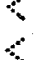 & 0.122 \\
\hline$-A$ & $<$ & $\begin{array}{l}0.122 \\
0.122\end{array}$ \\
\hline$C E$ & $<$ & 0.244 \\
\hline TH & $\varsigma$ & 2.44 \\
\hline
\end{tabular}


THEFMOCHEM/GEO

32

$31 \mathrm{~A}$

ELEMENT

CONCENTFATION (FFM

\begin{tabular}{|c|c|c|}
\hline NA & & 24 \\
\hline $\begin{array}{l}K \\
C_{A}\end{array}$ & 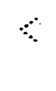 & $\frac{1}{3} \cdot 22$ \\
\hline MG & & 1 \\
\hline$F E$ & & 1.83 \\
\hline$A L$ & & $4 \cdot 1$ \\
\hline SI02 & & 25 \\
\hline $\begin{array}{l}T I \\
F\end{array}$ & $\varkappa$ & 0.122 \\
\hline $\begin{array}{l}\text { F } \\
\text { SFi }\end{array}$ & 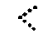 & 0.610 \\
\hline $\begin{array}{l}\text { SFi } \\
\text { HA }\end{array}$ & 0 & 0.07 \\
\hline$v$ & 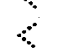 & 0.610 \\
\hline CF & 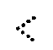 & $\begin{array}{l}1.22 \\
0.049\end{array}$ \\
\hline MN & 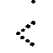 & 0.244 \\
\hline $\mathrm{CO}$ & 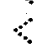 & 0.024 \\
\hline$N I$ & $\measuredangle$ & 0.122 \\
\hline $\begin{array}{l}\mathrm{CU} \\
\mathrm{MO} .\end{array}$ & 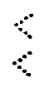 & $\begin{array}{l}0.061 \\
1.22\end{array}$ \\
\hline$B$ & 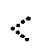 & 0.244 \\
\hline II & $\measuredangle$ & $\begin{array}{l}0.3 \\
0.061\end{array}$ \\
\hline G & $<$ & 0.049 \\
\hline 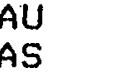 & $\zeta$ & $\begin{array}{l}0.098 \\
0.610\end{array}$ \\
\hline $\mathrm{B}$ & $\therefore$ & 0.732 \\
\hline[ & $\varsigma$ & 2.44 \\
\hline & $\lessdot$ & 6.10 \\
\hline$E$ & 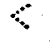 & 1.22 \\
\hline & 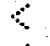 & 0.122 \\
\hline & ๔ & 0.122 \\
\hline & $\because$ & 0.049 \\
\hline & 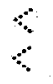 & $\begin{array}{l}0.005 \\
0.122\end{array}$ \\
\hline Fi & $\because$ & 0.122 \\
\hline$A$ & $<$ & 0.122 \\
\hline$E$ & 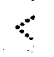 & 0.244 \\
\hline$H$ & $<$ & 2.44 \\
\hline
\end{tabular}




\section{THEFMOCHEM/GEO}

33

$32 \mathrm{~A}$

ELEMENT

CONCENTFATION (F.FM)

\begin{tabular}{|c|c|c|}
\hline$N A$ & & 57 \\
\hline $\begin{array}{l}K \\
C A\end{array}$ & $\therefore$ & $\frac{1.22}{2}$ \\
\hline$M G$ & & 1.0 \\
\hline$F E$ & & 0.85 \\
\hline$A L$ & & 2.4 \\
\hline SI02 & & 92 \\
\hline TI & 5 & 0.122 \\
\hline$F$ & $\zeta$ & 0.610 \\
\hline SFi & & 0.06 \\
\hline$B A$ & 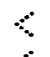 & 0.610 \\
\hline v & $\lessdot$ & 1.22 \\
\hline$C F$ & ¿ & 0.049 \\
\hline $\begin{array}{l}\mathrm{MN} \\
\mathrm{CO}\end{array}$ & $\zeta$ & $\begin{array}{l}0.244 \\
0.024\end{array}$ \\
\hline$N I$ & $<$ & 0.122 \\
\hline $\mathrm{Cu}$ & 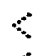 & 0.061 \\
\hline MO & $<$ & 1.22 \\
\hline$F \cdot E$ & $<$ & 0.244 \\
\hline $\begin{array}{l}\mathrm{ZN} \\
\mathrm{CI}\end{array}$ & 3 & 0.122 \\
\hline$A G$ & $<$ & $\begin{array}{l}0.061 \\
0.049\end{array}$ \\
\hline $\begin{array}{l}A U \\
\text { AS }\end{array}$ & 8 & $\begin{array}{l}0.098 \\
0.610\end{array}$ \\
\hline$S B$ & $\therefore$ & 0.732 \\
\hline BI & $<$ & 2.44 \\
\hline$T E$ & $<$ & 6.10 \\
\hline $\begin{array}{l}\text { TE } \\
\text { SN }\end{array}$ & 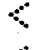 & 1.22 \\
\hline $\begin{array}{l}5 N \\
W\end{array}$ & $\measuredangle$ & $\begin{array}{l}0.122 \\
0.122\end{array}$ \\
\hline LI & ৫ & 0.049 \\
\hline${ }_{E}^{G E}$ & $\therefore$ & $\begin{array}{l}0.005 \\
0.1\end{array}$ \\
\hline$Z F$ & $\lessdot$ & 0.122 \\
\hline $\begin{array}{l}\mathrm{LA} \\
\mathrm{CE}\end{array}$ & 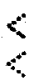 & $\begin{array}{l}0.122 \\
0.244\end{array}$ \\
\hline TH & $\because$ & 2.44 \\
\hline
\end{tabular}




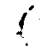

THEFMOCHEM /GEO

$34 \quad 33 A$

ELEMENT

$N A$

$K$

$C A$

$M G$

FE

AL.

SIO2

TI

F

$S F$

BA

U

CF

MN

$\mathrm{CO}$

NI

$\mathrm{CU}$

MO

FB

ZN

CD

AG

AU

AS

SB

EI

$U$

TE

SN

W

LI

BE

E

ZFi

LA

CE

TH
CONCENTRATION (FFM)

145

1.22
2
1
1.10
2.9

104
$\therefore \quad 0.122$

0.610

0.05

0.610

1.22

0.049

0.244

0.024

0.122

0.061

1.22

0.244

0.122

0.061

0.049

0.098

0.610

0.732

2.44

6.10

1.22

0.122

0.122

0.049

0.005

0.122

0.122

0.122

0.3

2.44 


\section{FIGURE $C 1$}

VOLCANIC STRATIGRAPHY AND BOTTOM HOLE TEMPERATURES DURING DRILLING FOR GEO N-3, NEWBERRY VOLCANO, OREGON. Because BHTs are generalized in this figure, the reader should refer to Table Bl for more detailed information. Note the bimodal character with more felsic units from (3200-3753) feet. The lithographic column was constructed as a result of geologic logging and comparisons to geochemical analyses. Temperature data comes from drilling reports, and GEO personnel are responsible for the stratigraphic interpretations. The whole-rock analyses are included in Tables $\mathrm{C} 1 / 1$ and $\mathrm{C} 1 / 2$. 


\section{TEMPERATURE GRADIENT CORE HOLE SUMMARY}

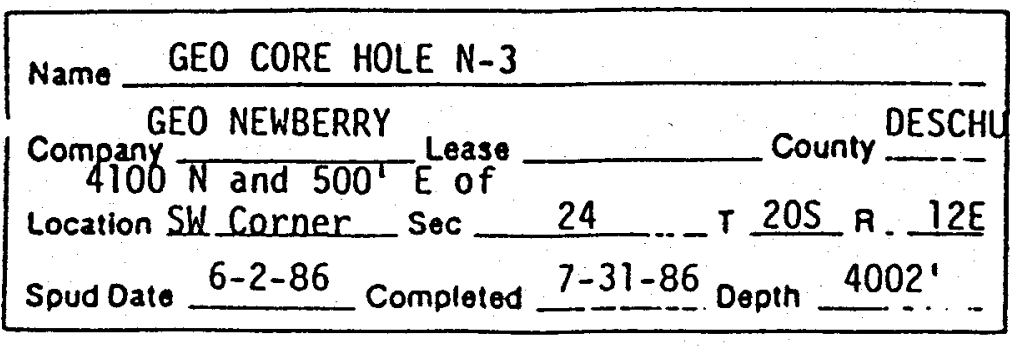

\begin{tabular}{|c|c|c|}
\hline & OLE TEMPE & WHILE \\
\hline W Feat & $\square$ Moters & $\otimes \cdot F$ \\
\hline
\end{tabular}

\begin{tabular}{|c|c|c|c|c|c|}
\hline DEPTH & TEMP & DEPTH & TEMP & DEPTH & TEMP \\
\hline 565.5 & $<60$ & 2767.5 & $<60$ & & \\
\hline 663 & $<60$ & 2864 & 64 & & \\
\hline 942 & $<60$ & 3061 & $77 / 78$ & & \\
\hline 1177 & 60 & 3160 & $103 / 103$ & & \\
\hline 1272 & 64 & 3213 & $103 / 103$ & & \\
\hline 1381.5 & 63 & 3320 & $94 / 94$ & & \\
\hline 1477 & $<60$ & 3377.5 & $92 / 92$ & & \\
\hline 1572 & $<60$ & 3422 & $110 / 110$ & & \\
\hline 1670.5 & $<60$ & 3463.5 & 123 & & \\
\hline 1733 & $<60$ & 3509 & $103 / 103$ & & \\
\hline 1845 & $<60$ & 3612 & $103 / 101$ & & \\
\hline 1947 & $<60$ & 3562 & $106 / 105$ & & \\
\hline 2044 & $<00$ & 3709 & $105 / 90$ & & \\
\hline 2092 & $<60$ & 3662 & $101 / 101$ & & \\
\hline 2182 & $<60$ & 3763 & $102 / 103$ & & \\
\hline 2288.5 & $<60$ & 3858.5 & $103 / 104$ & & \\
\hline 2359.5 & $<60$ & 3812 & $135 / 136$ & & \\
\hline $24 \mathrm{Cl}^{\circ}$ & $<60$ & 3908.5 & $130 / 130$ & & \\
\hline 2563 & 64 & 3961 & $118 / 120$ & & \\
\hline 2663 & 60 & & & & \\
\hline
\end{tabular}

(

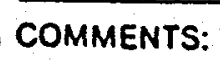

ARTESIAN FLOW $\approx 3800^{\circ}$
WATER ENTRIES:

HOT WATER ENTERS $23800^{\circ}$ FLOWS UP TO $21900^{\circ}$

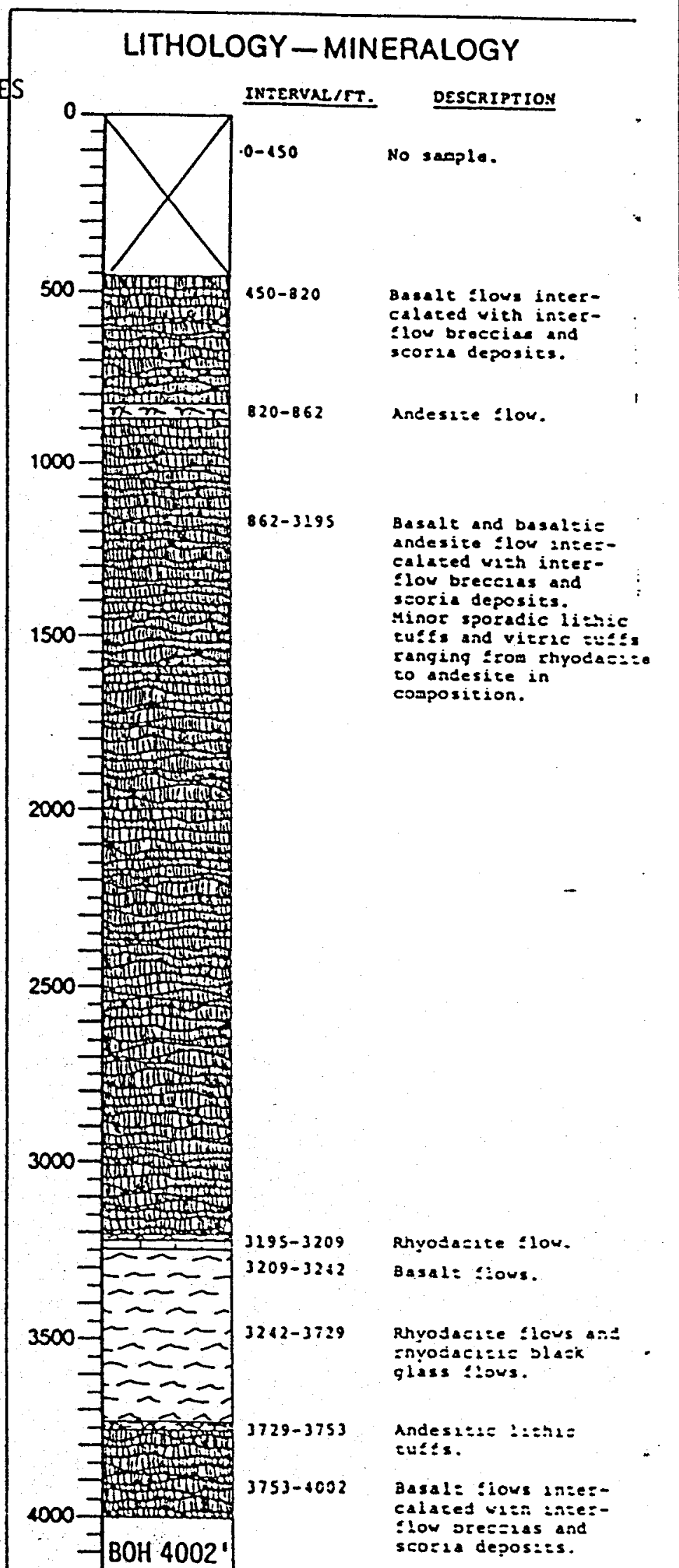

Figure Cl 
TABLE C $1 / 1$

ẂHOLE ROCK ANALYTICAL RESULTS OF CORE HOLE GEO N-3.

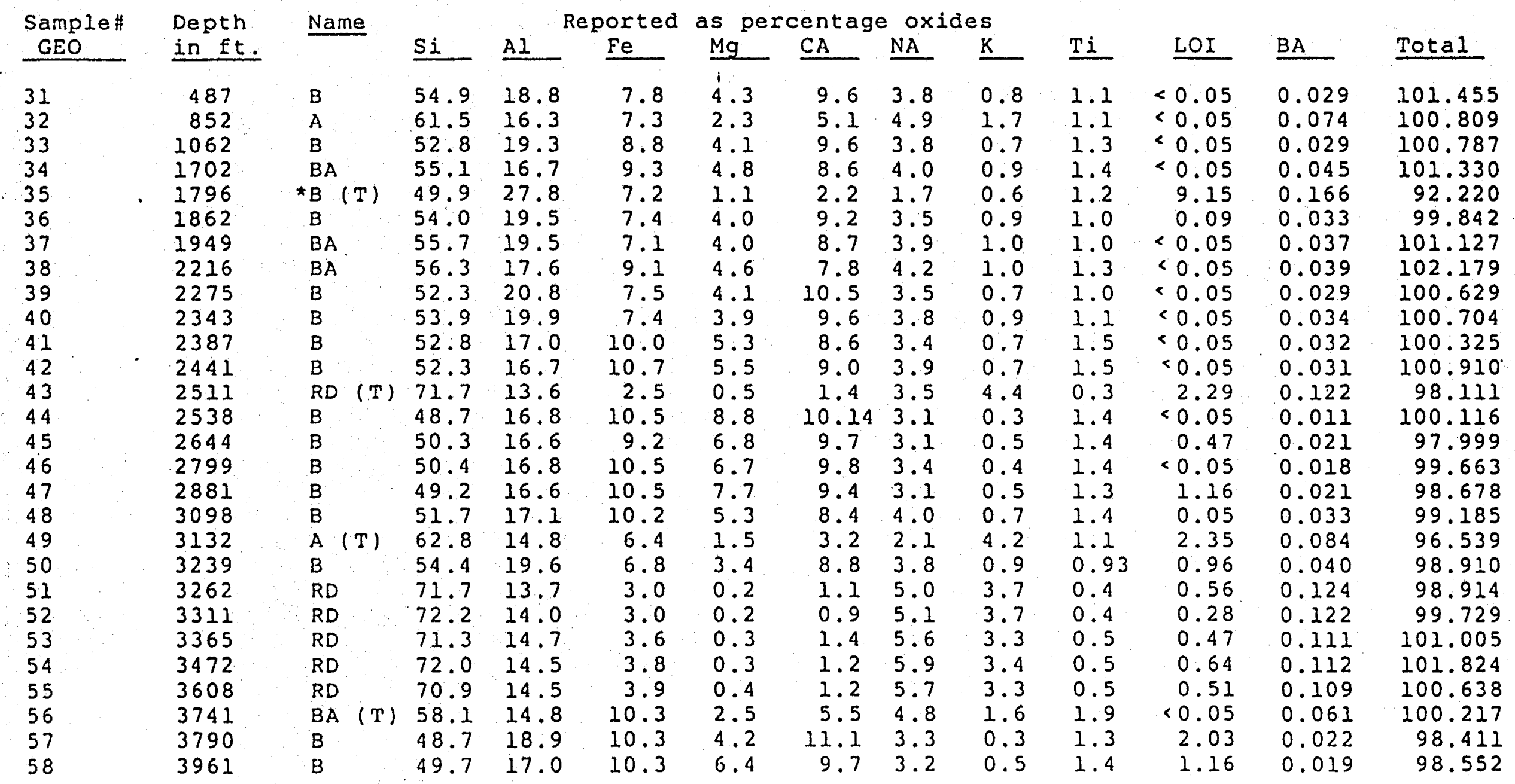

* (T) denotes analysis of ash in tuff unit

$\begin{array}{lcc}\text { Basalt } & <55 \% & \text { Si02 } \\ \text { Basaltic andesite } & 55-60 z & \text { Si02 } \\ \text { Andesite } & 60-65 \% & \text { Si02 } \\ \text { Dacite } & 65-70 z & \text { Si02 } \\ \text { Rhyodacite } & 70-75 z & \text { Si02 } \\ \text { Rhyolite } & >75 z & \text { Si02 }\end{array}$


TABLE C $1 / 2$

WHOLE ROCK ANALYTICAL RESULTS OF CORE HOLE GEO N-3

Reported as trace elements ppm

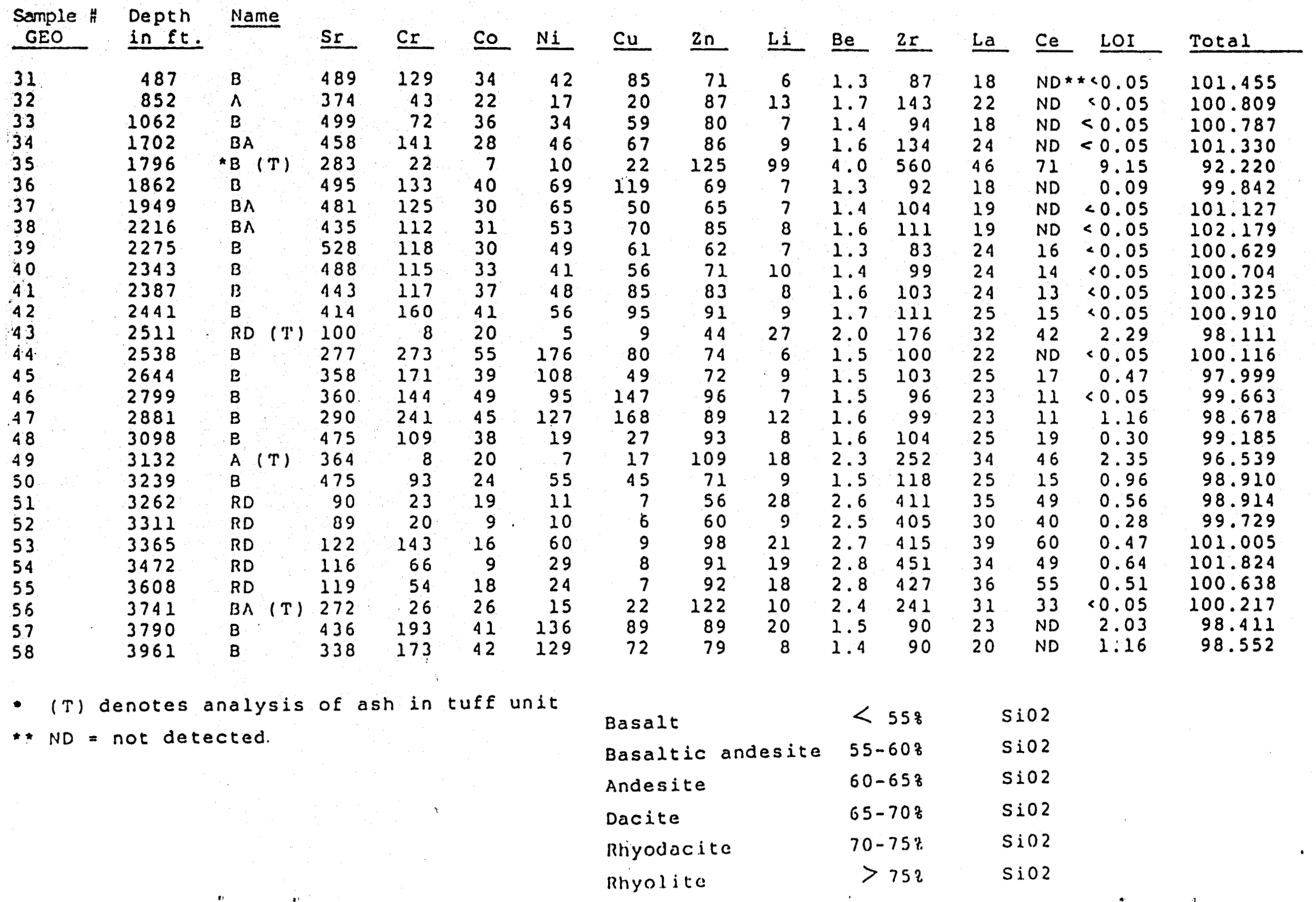




\section{FIGURE $\mathrm{C} 8$}

K/AR AGE DATES FOR CORE HOLE GEO N-3. Samples were submitted to the University of Arizona Laboratory of Isotope Geochemistry where rocks were ground, sieved to 100-150 mesh, and the feldspar-rich fraction concentrated using magnetic and heavy-liquid separation techniques. The basic data is included in Table $\mathrm{C} 8$. 


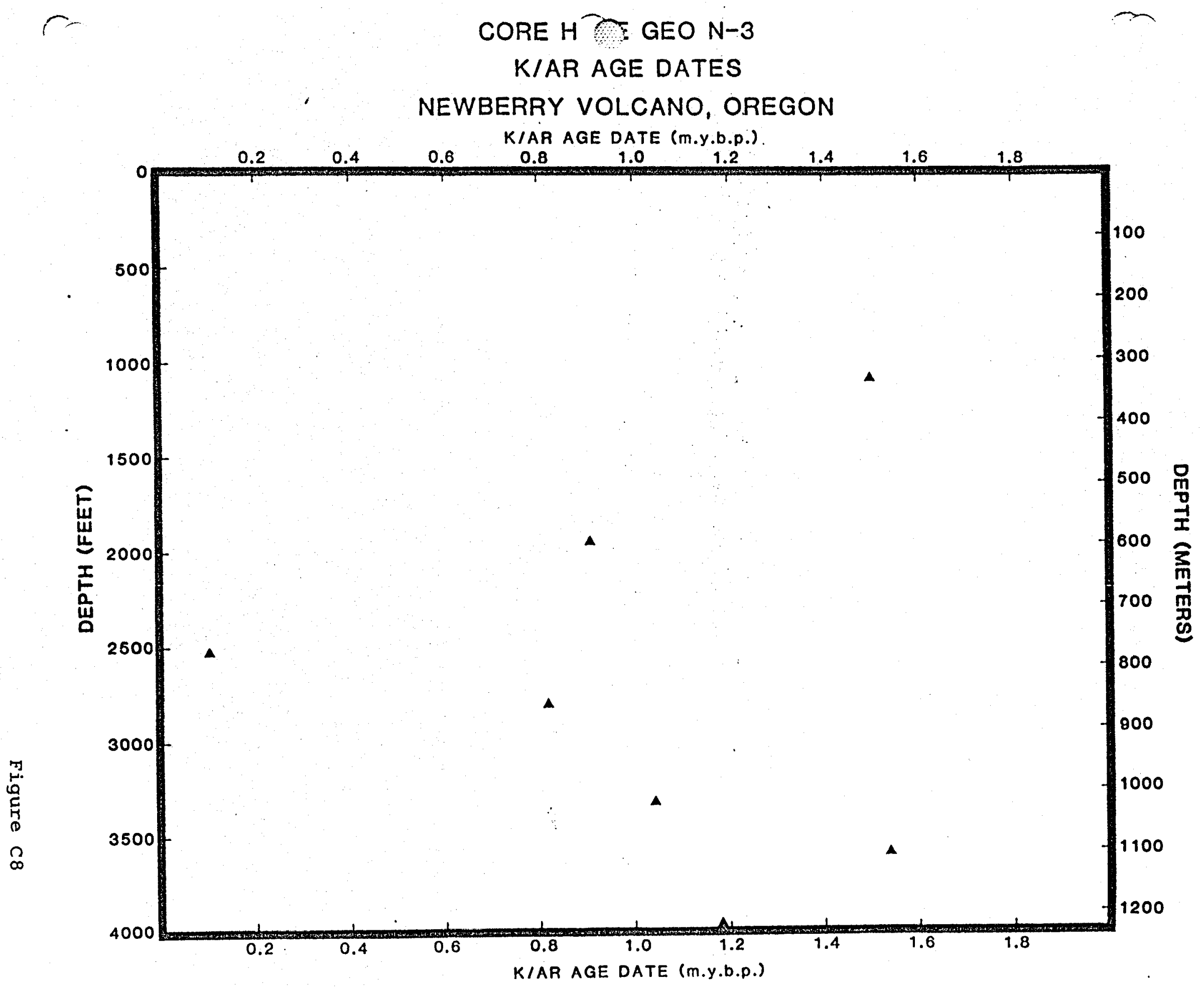


TABLE C8

K/AR AGE DATES: CORE HOLE GEO N-3

Newberry Volcano, Oregon

\begin{tabular}{|c|c|c|c|c|}
\hline $\begin{array}{l}\text { Sample \# } \\
\text { GEO }\end{array}$ & $\begin{array}{c}\text { Sample \# } \\
\text { U.A.* }\end{array}$ & Depth/ft. & Description & $\begin{array}{l}\text { Age } \\
\text { (mybp) }\end{array}$ \\
\hline 1 & $86-207$ & 1062 & phyric basalt & $1.50+0.63$ \\
\hline 2 & $86-208$ & 1949 & $\begin{array}{l}\text { phyric basaltic } \\
\text { andesite }\end{array}$ & $0.911+0.188$ \\
\hline 3 & $86-209$ & 2524 & lithic tuff & $0.109+0.081$ \\
\hline 4 & $86-210$ & 2799 & basalt & $0.819+0.113$ \\
\hline 5 & $86-211$ & 3312 & rhyodacitic flow & $1.04+0.03$ \\
\hline 6 & $86-212$ & 3608 & rhyodacitic flow & $1.54+0.05$ \\
\hline 7 & $86-213$ & 3961 & basalt & $1.18+0.30$ \\
\hline
\end{tabular}

* University of Arizona Isotope Laboratory 
University of Arizona

Isotope Geochemistry Laboratory

Date of Report: 9 Feb 1987
Project:GEO-NEWBERRY Crater Inc

Clife Walkey

Walter Randall

Sample Number

UAKA $86-207 . \quad$ Originator's $-\mathrm{N}-3 \# \mathrm{I}$

Sample Information

Basalt, groundmass feldspar concentrate,

Newberry Volcano, east of High Cascade axis, Oregon

Analytical Data

Potassium

Data Mean

$-----------$

$0.471 \quad 0.472$

0.472

0.472

0.474 $\begin{array}{cl}\text { Radiogenic Ar pm/g } \\ \text { Data } & \text { Mean }\end{array}$

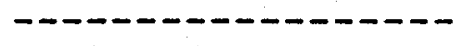

1.376

1.136

1.171

1. 209

1.270
1.232

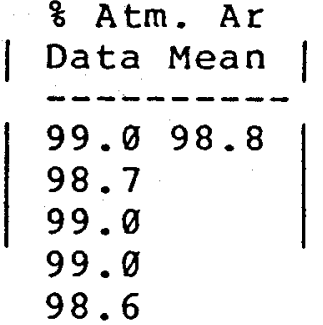

Reported

Date + Err $-------c---$

$1.50+0.63$

Tample Number

UAKA $86-208$

Originator's $-\mathrm{N}-3 \# 2$

Sample Information

Basalt, groundmass feldspar concentrate,

Newberry Volcano, east of High Cascade axis, Oregon

Analytical Data

Potassium

Data Mean

$----------$

$0.727 \quad 0.728$

0.728

0.730

\begin{tabular}{|c|c|}
\hline $\begin{array}{c}\text { Radiogenic } \\
\text { Data }\end{array}$ & $\begin{array}{l}\text { Ar } \mathrm{pm} / \mathrm{g} \\
\text { Mean }\end{array}$ \\
\hline $\begin{array}{l}1.249 \\
1.173 \\
1.117 \\
1.066\end{array}$ & 1.151 \\
\hline
\end{tabular}

\& Atm. Ar
Data Mean |
-95.996 .3
96.2
96.4

96.8

\author{
Reported \\ Date + Err \\ - \\ $0.911+0.188$
}


University of Arizona

Isotope Geochemistry Laboratory

Date of Report: 9 Feb 1987
Project:GEO-NEWBERRY Crater Inc Cliff Walkey Walter Randal1

Sample Number

UAKA 86-209 Originator's $-\mathrm{N}-3 \# 3$

Sample Information

Lithic tuff, feldspar concentrate with some glass, Newberry Volcano, east of $\mathrm{High}$ Cascade axis, Oregon

Analytical Data

Potassium

Data Mean

$----\cdots------$

$3.604 \quad 3.614$

3.626

3.648

3.577
Radiogenic Ar pm/g

Data Mean

$\begin{array}{cc}0.696 & 0.686 \\ 0.777 & \\ 0.464 & \\ 0.868 & \end{array}$

$\%$ Atm. Ar Data Mean

99.799 .4

99.6

99.8

98.7
Reported

Date + Err

$-0-0 .-0 .-$.

Sample Number

$$
\text { UAKA 86-210 Originator's }-\mathrm{N}-3 \# 4
$$

Sample Information

Basalt, groundmass feldspar concentrate,

Newberry Volcano, east of High Cascade axis, Oregon

Analytical Data

Potassium

Data Mean

$-\cdots-\cdots-\cdots-$

$0.388 \cdot 0.387$

0.383

0.384

0.398

0.386

0.381

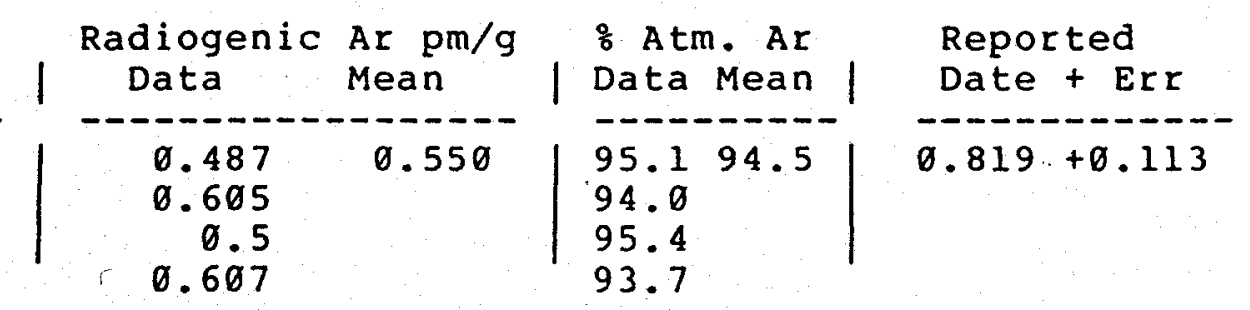

RECEIVED

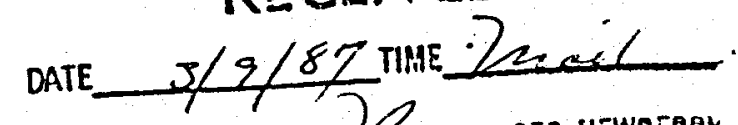

BY G:O NEHBERRY

GEO OFESTIR CORP 
(Iniversity of Arizona isotope Geochemistry Laboratory Date of Report: $9 \mathrm{Feb} 1987$

Sample Number

UAKA 86-211 Originator's $-\mathrm{N}-3 \# 5$

Sample Information

Rhyodacite, groundmass feldspar concentrate,

Newberry Volcano, east of High Cascade axis, oregon

Analytical Data

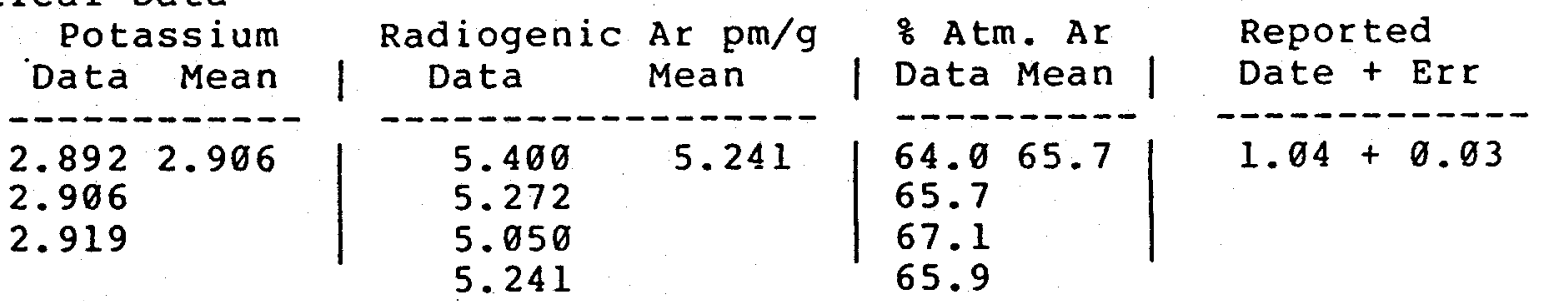

Sample Number

UAKA 86-212 Originator's -N $3 \# 6$

Sample Information

Rhyodacite, groundmass feldspar concentrate, Newberry Volcano, east of High Cascade axis, Oregon

Analytical Data

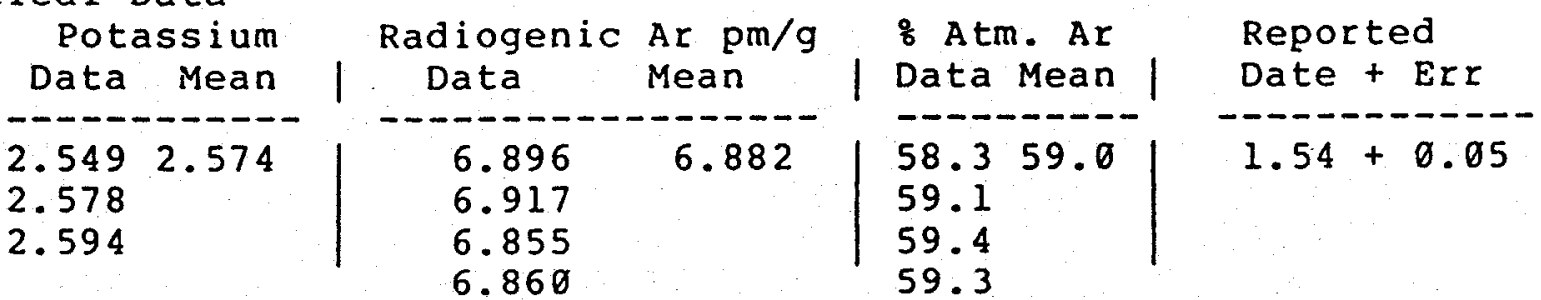

Sample Number

UAKA 86-213 Originator's - N-3 \#7

Sample Information

Basalt, groundmass feldspar concentrate,

Newberry Volcano, east of High Cascade axis, Oregon

Analytical Data

Potassium

Data Mean

0.351
0.354
0.357

Radiogenic Ar $\mathrm{pm} / \mathrm{g}$ Datà Mean

$0.762 \quad 0.722$
0.773
0.631

8 Atm. Ar Data Mean ।

97.697 .8

97.6

98.1
Reported

Date + Err

$1.18+0.30$ 
Thin Section Descriptions

Newberry Crater Core Hole N-3

\begin{abstract}
Depth: $\quad 487^{\prime}$
Rock Type: (from whole rock geochemistry) Basaltic Andesite

Description: Holocrystalline, serfate-glomeroporphyritic; Phenocrysts of subhedral to euhedral labradorite plagloclase laths up to $2.1 \mathrm{~mm}$, minor subhedral to euhedral olivine crystals up to $0.9 \mathrm{~mm}$ and trace rounded to subhedral augite crystals up to $0.6 \mathrm{~mm}$ in an intergranular matrix of labradortte microlaths, granular clinopyroxene <.01mu and granular iron ore <.01mm.
\end{abstract}

Depth: $\quad 848^{\circ}$

Rock Type: Andesite

Description: Holocrystalline, very fine grained equigranular, pilotaxitic. Flow banded euhedral laths and microlaths of labradorite plagloclase up to $0.4 \mathrm{~mm}$ in an intergranular matrix of granular clinopyroxene $<.01 \mathrm{~mm}$ and granular iron ore.

Depth: 1062'

Rock Type: Basaltic Andesite

Description: Holocrystalline, serlate-glomeroporphyritic, locally subophitic; Euhedral laths of labradorite plagloclase, 0.1 to $2.6 \mathrm{~mm}$, and trace phenocrysts of subhedral to rounded olivine up to $0.8 \mathrm{~mm}$ in a subophitic to granular matrix of clinopyroxene with very rare granular tron ore $<.01 \mathrm{~mm}$.

Depth: $\quad 1266^{\circ}$

Rock Type: N/A

Description: Hypohyaline, crystal lap1111 tuff, unwelded: Globular to arcuate lap1111 of phenocryst-bearing glass and punice up to $6.0 \mathrm{~mm}$ and minor (10\%) lap1111 of basaltic cinder scorla. 0.1 to $3.0 \mathrm{~mm}$, in a frothy vitroclastic glass groundmass. Phenocrysts consist of euhedral to subhedral labradorite laths, $<.01$ to $0.4 \mathrm{~mm}$, and rare euhedral columar augite, <0.1 to $0.2 \mathrm{~mm}$. Glass and pumice has been altered to a yellow brown to red brown palagonite.

Depth: $\quad 1353^{\prime}$

Rock Type: Basaltic Andesite

Description: Holocrystalline, seriate-giomeroporphyritic, vesicular: Euhedral laths of labradorite. .01 to $1.8 \mathrm{~mm}$, and subhedral to rounded 
grains of ollvine up to $0.8 \mathrm{~mm}$ in an Intergranular matrix of rounded to anhedral grains of clinopyrcxene, 0.005 to $0.2 \mathrm{~mm}$, and rare iron ores $<.01 \mathrm{~mm}$. Vesicles are elongate, generally rounded cavities up to $2.5 \mathrm{~mm}$ in length; diktytaxitic.

Depth: $\quad 1702^{\prime}$

Rock Type: Basaltic Andesite

Description: Holocrystalline, fine grained equigranular, weakly p1lotaxitic, veslcular. Euhedral laths of labradorite plagloclase, $<0.01$ to $0.6 \mathrm{~mm}$, and minor subhedral to rounded grains of ollvine and augite, up to $0.3 \mathrm{~mm}$, In an intergranular matrix of granular clinopyroxene, ollvine and trace Iron oxtdes <.01mim. Vesicles are subrounded bubble cavities up to $0.4 \mathrm{~mm}$; diktytaxitic.

Depth: $\quad 1791^{\prime}$

Rock Type: N/A

Descrlption: Hypohyaline, crystal lap1111 tuff, unwelded; Crystal-bearing glassy lap1111 and rare puniceous fragments up to 7.0mm rounded fragments of cinder scorla and basalt up to $6.0 \mathrm{~mm}$ in a crystalrich ashy matrix. Abundant euhedral laths of plagloclase (labrador1te?), $<0.1$ to $0.6 \mathrm{~mm}$, very minor columar to anhedral phenocrysts of augite up to $0.5 \mathrm{~mm}$ and very rare ollvine crystals up to $0.4 \mathrm{~mm}$. Glass materlal has been altered to jellow brown palagontte.

Depth: $\quad 1^{\circ}$

Rock Type: Basalt

Description: Hypohyaline, vitric tuff. densely welded. Agglomerated lapilli and flamme of jellow brown glass up to $1 \mathrm{~cm}$ in length in a matrix of yellow brown to reddish brown crystal-rich ash and vitroclastic material. Fluldal banding well developed. Phenocrysts tnclude plagloclase, clinopyroxene and iron ore. Also contains 11thic fragments of cinder scorla, basalt and rhyodacite(?).

Depth: $\quad 1827^{\circ}$

Rock Type: N/A (Basaltic Andesite?)

Description: Hypohyaline, porphyritic, vesicular: Euhedral laths of labradortte plagloclase, $<0.01$ to $1.0 \mathrm{~mm}$, with trace subhedral to rounded grains of clinopyroxene and very rare olivine $<0.1 \mathrm{~mm}$ in a frothy. vestcular green glass groundmass. Round bubble-shaped vesicles up to $0.5 \mathrm{~mm}$ are also present. 


\begin{abstract}
Depth: 1861'
Rock Type: Basaltic Andesite

Descrlption: Hypocrystalline, serlate-glomeroporphyritic: Euhedral laths of labradorlte plagloclase, $<0.01$ to $3.4 \mathrm{~mm}$, with minor subhedral. embayed olivine, $<0.01$ to $1.2 \mathrm{~mm}$, and trace subhedral to granular augite. $<0.01 \mathrm{~mm}$ to $0.6 \mathrm{~mm}$. in an 1ntersertal dark green glassy groundmass. Groundmass contalns abundant microlites and cryptolites of plagloclase, clinopyroxene and fron ore.
\end{abstract}

Depth: 1949'

Rock Type: Basaltic Andesite

Description: Holocrystalline, serfate-glomeroporphyritic; Euhedral laths of labradorite plagioclase, 0.02 to $4.0 \mathrm{~mm}$, with rare subhedral, embayed crystals of ollvine up to $1.1 \mathrm{~mm}$ and very rare subhedral columar augite up to $0.35 \mathrm{~mm}$, in an intergranular matrix of plagioclase microlites, granular clinopyroxene and granular iron ore. Olivine is partially altered to lddingsite.

Depth: 2102'

Rock Type: N/A (Basaltic Andes1te?)

Description: Holocrystalline, seriate glomeroporphyritic: Euhedral laths of labradorite plagioclase, 0.02 to $3.0 \mathrm{~mm}$, with rare subhedral to rounded grains up to $0.3 \mathrm{~mm}$ of ollvine and augite in an intergranular matrix of plagloclase microlites and granular cilinopyroxene and 1ron ore $<0.01 \mathrm{~mm}$. 011vines are partlally altered to 1ddingsite.

Depth: 2216

Rock Type: Basaltic Andesite

Description: Holocrystalline, serlate, pllotaxitic. Euhedral and embayed and sleve-textured bytownite plagloclase laths (approximately $5 \%$ of total rock) up to $2.3 \mathrm{~mm}$ and rare embayed grains of ollvine up to $0.3 \mathrm{~mm}$ in an intergranular matrix of labradorite plagloclase 1aths. granular clinopyroxene and granular iron ore. Microlites display subparallel orientations.

Depth: 2275

Rock Type: Basaltic Andesite

Description: Holocrystalline, serlate-glomeroporphyritic, vesicular: Euhedral laths of labradorite plagtoclase, 0.2 to $4.0 \mathrm{~mm}$, with minor subhedral to rounded grains of augite. up to $0.4 \mathrm{~mm}$, and rare subhedral. embayed grains of ollvine. up to $0.7 \mathrm{~mm}$. In an intergránular matrix of plagloclase microlites, granular clinopyroxene and granular Iron oxides. Vesicles are rounded to elongate cavities, 0.2 to $0.8 \mathrm{~mm}$ : diktytaxit1c. 
Depth: $\quad 2343^{\prime}$

Rock Type: Basaltic Andesite

Description: Holocrystalline, seriate-glomeroporphyritic. Euhedral laths of labradortte plagloclase, 0.1 to $3.2 \mathrm{~mm}$, with rare subhedral, embayed ollvine grains up to $0.3 \mathrm{~mm}$ and subhedral. embayed augite grains up to $0.4 \mathrm{~mm}$ in an intergranular matrix of plag10clase microlites, granular clinopyroxene and granular iron ore.

Depth: $\quad 2387^{\prime}$

Rock Type: Basaltic Andesite

Description: Holocrystalline, very fine grained equigranular, ophimottled, pllotaditic, vesicular; Euhedral labradorite plagloclase laths, 0.1 to $0.3 \mathrm{~mm}$ with rare phenocrysts up to $0.6 \mathrm{~mm}$ in an intergranular matrix that grades from granular clinopyroxene with subordinant granular iron ore to subophitic clinopyroxene to Intermeshed ophimottle plates of clinopyroxene up to $0.4 \mathrm{~mm}$. Vesicles are irregular to rounded cav1ties up to $0.75 \mathrm{~mm}$; diktytaxitic. Plagloclase microlaths display subparallel orlentations.

Depth: $\quad 2441^{\prime}$

Rock Type: Basaltic Andesite

Description: Holocrystalline, very fine grained equigranular, pilotaxitic: Euhedral leths of labradorite plagloclase. $<.01 \mathrm{~mm}$ to $0.2 \mathrm{~mm}$. In an intergranular matrix of granular clinopyroxene and granular Iron oxtdes. Very minor. $<5 \%$, Intersertal green glass.

Depth: $\quad 2511^{\circ}$

Rock Type: Rhyodacite

Description: Holohyaline, puntce lap1111 tuff, poorly welded: Rounded to Irregularly-shaped punice fragments up to 3rm and trace cinder and basaltic clasts up to $0.8 \mathrm{~mm}$ in a vitroclastic matrix of glass shards and ash. Rare embayed plagloclase phenocrysts up to $0.2 \mathrm{~mm}$.

Depth: $\quad 2524^{\prime}$

Rock Type: N/A (Rhyodac1te?)

Description: Holohyaline, pumice lap1l11 tuff, poorly welded. Pumice lapilil up to $5 \mathrm{~mm}$, and 11thic fragments of cinders and basalt up to $4 \mathrm{~mm}$. In a vitroclastic matrix of 8 lass shards and ash. Similar to $2511^{\circ}$ but has a higher percentage of 11thics and larger pumice lapti11. 
Depth: 2538'

Rock Type: Thole11tic Basalt

Description: Holohyaline, serlate; Euhedral laths of labradorite plagioclase. 0.1 to $0.7 \mathrm{~mm}$. with abundant rounded grains of olivine, 0.1 to $0.4 \mathrm{~mm}$. Inftiled by subophttic (1ocally granular) clinopyroxene. Very rare granules of tron ore $<0.1 \mathrm{~mm}$. Sample has a microdiabasic texture. Olivines are commoniy rimued by Iddingsite.

Depth: $\quad 2644^{\prime}$

Rock Type: Thole11t1c Basalt

Description: Holocrystalline, serlate, vesicular; Euhedral laths of labradorite plagloclase. 0.1 to $1.8 \mathrm{~mm}$, with minor amounts of rounded to subhedral ollvine grains, $<0.1$ to $0.2 \mathrm{~mm}$. Infilled by subophitic clinopyroxene and granular iron ore. Very minor amount (<27) of Intersertal brown glass. Vesicles are rounded cavities which are commonly lined with brown glass; diktytaxitic. Very similar to $2538^{\prime}$.

Depth: $2799^{\circ}$

Rock Type: Tholelitic Basalt

Description: Hypocrystalline, fine grained equigranular; Euhedral 1aths of labradorite plagioclase, $<0.1$ to $0.5 \mathrm{~mm}$, and rare subhedral to rounded grains of ollvine, $<0.1 \mathrm{~mm}$. Infllled by subophltic to. weakly ophimottled clinopyroxene. Minor amount, approximately 5\%. of Intersertal dark brown opaque devitrified glass.

Depth: $\quad 2881^{\prime}$

Rock Type: Thole11tic Basalt

Description: Hypocrystaline, fine grained equigranular; ophimottled; Euhedral laths of Labradorite plag1oclase, $<0.1$ to $0.6 \mathrm{~mm}$, and very rare subhedral, embayed olivine up to $0.4 \mathrm{~mm}$. Infilled partialiy by ophitic crystals of cilnopyroxene up to $1.4 \mathrm{~mm}$ across and partially by intersertal brownlsh green glass. Clinopyroxene to glass rat10 is approximately $2: 1$. Very rare eranular iron ore.

Depth: $3020^{\prime}$

Rock Type: N/A (Thole11tic Basa1t)

Description: Hypocrystalline, very fine grained equigranular, vesicular: Euhedral microlaths of Labradortte plagloclase, up to $0.4 \mathrm{~mm}$ but generally $<0.1 \mathrm{~mm}$. with very minor granular clinopyroxene and Iron ore. $<0.01 \mathrm{~mm}$. In a highly vestcular intersertal groundmass of dark brown opaque devitrified glass. Vesicles are small. $<0.2 \mathrm{~mm}$, and round. 
Depth: $\quad 3087^{\prime}$

Rock Type: N/A (Thole11tic Basalt?)

Description: Holocrystalline, very fine grained equigranular: Euhedral laths of labradorite plagloclase, $<0.1$ to $0.3 \mathrm{~mm}$, with rare phenocrysts up to $0.9 \mathrm{~mm}$. In an intergranular matrix of granular clinopyroxene $<0.01 \mathrm{~mm}$ and granular 1ron ore $<0.01 \mathrm{~mm}$.

Depth: $\quad 3098^{\circ}$

Rock Trpe: Tholelitic Basalt

Description: Holocrystalline, fine grained equigranular, pilotaxitic; Euhedral laths of labradorite plagloclase, $<0.1 \mathrm{~mm}$ to $0.2 \mathrm{~mm}$ with rare phenocrysts up to $4.0 \mathrm{~mm}$, and minor amounts of rounded to subhedral olivine, $<0.1 \mathrm{~mm}$ to $0.2 \mathrm{~mm}$, in an intergranular matrix of granular clinopyroxene $<0.01 \mathrm{~mm}$ and granular fron ore $<0.01 \mathrm{~mm}$. 011vine crystals are pervasive1y to completed replaced by 1ddingsite and Iron oxides.

Depth: $\quad 3122^{\circ}$

Rock Type: Dac1te

Description: Hypohyaline, 11thic lapilli crystal tuff, welded; Globular to spindle-shaped lapill1 and flanme of crystal-bearing devitrified glass up to $15 \mathrm{~mm}$ in length in a crystal-rich vitroclastic matrix of arcuate glass shards, ash and glass dust. Phenocrysts in the gless lapili1 and matrix are 1dentical consisting of andesine plagloclase laths, $<0.05$ to $0.8 \mathrm{~mm}$, and rare columar crystals of augite, $<0.01$ to $0.15 \mathrm{~mm}$. Tuff also contains approxdmately $20 \%$ lithic fragments ranging up to 6.0rm in length. Lithics are basalt, cinders, rhyodacite(?) and pumice. Glass and matrix are brown to yellow brown.

Depth: $\quad 3143^{\circ}$

Rock Type: N/A (Dacite or Andesite)

- Description: Hypohyaline, 11thic vitric tuff, welded. Subangular to rounded 11thlc fragments, $<0.1$ to $10 \mathrm{~mm}$. In a crystal-bearing dusky red brown glassy matrix. Lithic fragments are extreme1y varled: several basalts, basaltic cinder scorla, punice, rhyodacite and frothy red brown glassy material (pre-existing tuff?). Phenocrysts Includes euhedral. partially embayed labradite plagioclase laths up to $1.1 \mathrm{~mm}$ in length and subhedral to euhedral columnar augite up to $0.4 \mathrm{~mm}$ in length.

Depth: $\quad 3204^{\prime}$

Rock Type: N/A (Basaltic Andesite) 


\begin{abstract}
Description: Hypocrystalline, very fine grained equigranular; Mcrolltes and microlaths of labradortte plagloclase up to $0.3 \mathrm{~mm}$ in length. rare subhedral. embayed crystals of clinopyroxene up to $0.2 \mathrm{~mm}$ and rare polygonal 1 ron ore up to $0.1 \mathrm{~mm}$ in an intersertal matrix of pale green glass. Basaltic cinder scorla inclusions, $<0.1$ to $1.4 \mathrm{~mm}$ are also incorporated in the glassy matrix.
\end{abstract}

Depth: $3239^{\prime}$

Rock Type: Basaltic Andesite

Description: Hypocrystalline, serlate-glomeroporphyritic, vesicular. Euhedral labradortte plagloclase laths, 0.1 to $5 \mathrm{~mm}$. In an intergranular matrix of plagloclase microlites, granular clinopyroxene $<0.05 \mathrm{~mm}$ and opaque 1 ron ore $<0.01 \mathrm{~mm}$. Approximate $1 \mathrm{y} 20 \%$ of the groundmass is intersertal dark greenish gray dust-filled. devitrifled glass. Vesicles, $<0.1$ to $1.5 \mathrm{~mm}$, comprise approximate1y $15 \%$ of total area. Cavities range from irregular arcuate to rounded geometries. Vesicles are partialls to completely filled with greenish to greenish brown clays. There is also very minor replacement of plagloclase by greenish brown clays.

Depth: $\quad 3263^{\prime}$

Rock Type: N/A (Rhyolite?)

Description: Holohyaline, glass flow; Agglomerate of rounded, arcuate and spindle-shaped pale green glassy fragments up to $5 \mathrm{~mm}$. Glass displays flow banding and contains abundant crystaline of plagloclase. Individual glass fragments have devitrifled rims and open into trregular arcuate vold spaces partiy filled by black opaque material, yellow brown clays and spherlcal crystals of cristobalite up to .125m.

Depth: $\quad 3311^{\prime}$

Rock Type: Rhyolite

Description: Hypocrystalline, cryptocrystalline, pilotaxitic; Microlites of plagloclase, <0.1mm. in a cryptocrystalline groundmass with abundant crystallites of plagloclase and fron ore with some very pale green glass. Rock composed of planar bands ranging from approxdmate $1 y 0.075$ to $0.15 \mathrm{~mm}$. Platy fractures we 11 developed along planar lamina with red brown opaque iron oxides and intergrowths of euhedral trydymite and cristobalite crystals lining open volds. 


\begin{abstract}
Depth: $\quad 3352^{\prime}$
Rock Type: N/A (Basa1t?)

Description: Hypocrystalline, serlate, fine grained equigranular, pilotax1t1c, vestcular: Microlaths of labradortte plagloclase. 0.1 to $0.2 \mathrm{~mm}$. with rare phenocrysts up to $0.75 \mathrm{~mm}$ in an intergranular matrix of clinopyroxene and Iron ore granules <.05m grading Into an Intersertal groundmass of pale green glass. Glass constitutes approximately $20 \%$ of groundmass. Very rare of olivine up to $1.1 \mathrm{~mm}$ in length completely replaced by a fine grained mixture of Iddingsite, Iron oxtdes and sphene. Vesicles, up to $0.6 \mathrm{~mm}$ in length. are rounded elongate cavities partially filled by greenish clays; diktytaxitic.
\end{abstract}

Depth: $\quad 3365^{\circ}$

Rock Type: Rhyodacite

Description: Hypocrystalline, porphyrlt1c: Embayed laths of andesine plagioclase up to $0.8 \mathrm{~mm}$, subhedral embayed columnar augite up to $0.3 \mathrm{~mm}$, and polygonal Iron ore gratns up to $0.1 \mathrm{~mm}$, In a cryptofelsic groundmass. Rock is flow banded, characterized by irregular lamina of holocrystaline cryptofelsic material alternating with cryptofelsic materlal grading into dark opaque green glass. Sporadic fractures parallel to the flow banding, $<0.2 \mathrm{~mm}$, partially infilled with very fine grained cristobalite and calcite crystals.

Depth: $\quad 3472^{\prime}$

Rock Type: Rhyodac1te

Description: Holocrystalline, porphyrit1c; Subhedral embayed andesine plagioclase, laths up to 2.1nom, subhedral embayed columnar clinopyroxene up to 0.7 ma and polygonal to granular iron ore up to $0.1 \mathrm{~mm}$ in a cryptofelsic groundmass. Rare fractures, <0.1mm, are partially infilled by cristobalite and yellow brown clays.

Depth: $\quad 3541^{\circ}$

Rock Type: Rhyodacite

Description: Holocrystalline, porphyritic, pllotaxitic; Subhedral embayed andesine plagloclase, laths up to $1.95 \mathrm{~mm}$, rare subhedral embayed columnar auglte up to $0.3 \mathrm{~mm}$, and very rare 1 ron ore up to $0.1 \mathrm{~mm}$. In a cryptofelsic groundmass. Flow banded with minor fractures subparallel to flow banding up to $0.95 \mathrm{~mm}$ in width. Fractures contain drusy crystals of tridymite with interstitial calcite and tron oxides and also layers of yellow brown clays. 
Depth: $3608^{\circ}$

Rock Type: Rhyodac1te

Description: Holocrystalline, porphyritic; Trace amounts of phenocrysts consisting of subhedral embayed andesine laths up to $1.0 \mathrm{~mm}$. subhedral embayed augite crystals up to $0.2 \mathrm{~mm}$ and granular fron ore $<0.05 \mathrm{~mm}$ in a cryptofelsic groundmass.

Depth: $\quad 3741^{\prime}$

Rock Type: Basaltic Andesite

Description: Hypocrysta1line, serlate, vestcular; Euhedrai laths of labradortte plagtoclase, $<0.1 \mathrm{~mm}$ to $2.45 \mathrm{~mm}$, and minor rounded to subhedral columnar augite, $<0.1 \mathrm{~mm}$ to $0.5 \mathrm{~mm}$. In an intersertal matrix of dark gray green glass with abundant crystallites of clinopyroxene and iron ore. Approximately $20 \%$ of slide composed of 11thic inclusions ranging from $1.2 \mathrm{~mm}$ to $8.0 \mathrm{~mm}$ in 1 ength. L1thics include rhyodacite, basaltic cinder scorla and flow basalts of widely varying textures. Rims of some inclusions. especially rhyodacite, show evidence of partial melting. Vesicles range from <.1min to $2.2 \mathrm{~mm}$ in length characterized by rounded to elongate geometries. Vesicles are partially to completely filled with massive to euhedral saucer-shaped siderite crystals and red to yellow brown clays. Minor patchy replacement of glassy groundmass by siderite is also present adjacent to siderite-bearing vesicles.

Depth: $\quad 3790^{\circ}$

Rock Type: Tholefitic Basalt

Description: Hypocrystalline, serlate-fine grained equigranular, pilotaxitic. vesicular: Euhedral laths of labradorite plagloclase, 0.05 to $0.35 \mathrm{~mm}$, with rare rounded grains of augite less than $0.2 \mathrm{~mm}$ in an Intersertal matrix of black opaque devitrified glass with minor inclusions of granular clinopyroxene and fron ore $<.01 \mathrm{~mm}$. Pseudomorphs of ollvine completely replaced by red brown clays and carbonate are also present. Large round vesicles constitute approximately $5 \%$ of total area and range in size from 0.5 to 8mm. Vestcles are partlaily to completely infilled by botryoldal masses of clays (opaque black, dusky reddish brown. greenish brown. dark green). euhedral saucer-shaped siderite. and drusy aggregates of colorless calcite crystals. 
Depth: $3961^{\prime}$

Rock Type: Thole11tic Basalt

Description: Hypocrystalline, serlate-microdiabasic, vesicular; Euhedral laths of labradorite plagloclase, $<0.1 \mathrm{~mm}$ to $0.9 \mathrm{~mm}$, surrounded by subophitic platlets of augite up to $0.3 \mathrm{~mm}$ and partially by intersertal devitrified, altered glass with minor granules of Iron ore $<0.05 \mathrm{~mm}$. Glass is pervasively altered to red brown to brown clays. Vesicles are rare and consist of rounded cavities up to $0.6 \mathrm{~mm}$ which are partially to completely infilled by greentsh brown clays, radiating spherical crystals of siderite and very fine-grained mosaic aggregates of carbonate.

JNS: bk

GE87-150.jns 
Amygdaloidal and Frocture-Filling Secondary Minersl Assemblages in Samples from 0

Geothermol Field

by
Lori A. Bettison, M.S.

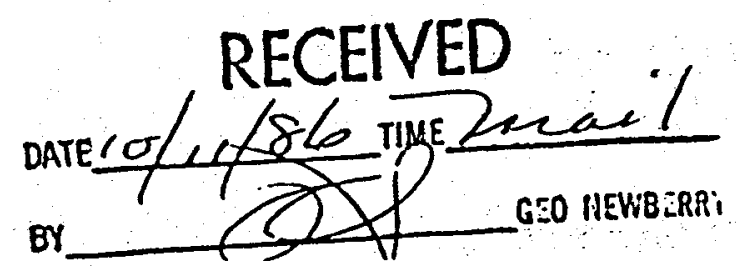




\section{SUMMARY}

Ten samples from various drill hole depths were examined with $X$-ray diffroction and secondary electron imaging on the sconning electron microscope. The following fracture and vesicle filling secondary minerels were identified: calcite, aragonite, siderite, morcosite, pyrite, tridymite, and magnesite. Table 1 lists the secondsry phases identified at the depth represented by each sample.

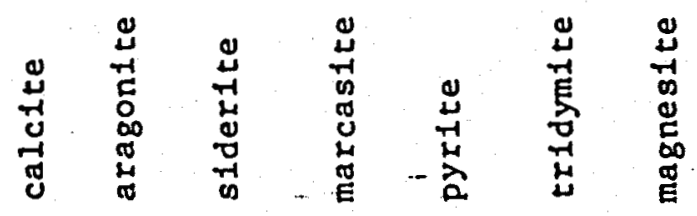

2882"

$3412^{\circ}$

$x$

$3470^{\circ}$

$3540^{\circ}$

$3580^{\circ}$

$3705^{\circ}$

$3770^{\circ}$

$3948^{\circ}$

$3970^{\circ}$

$3980^{\circ}$

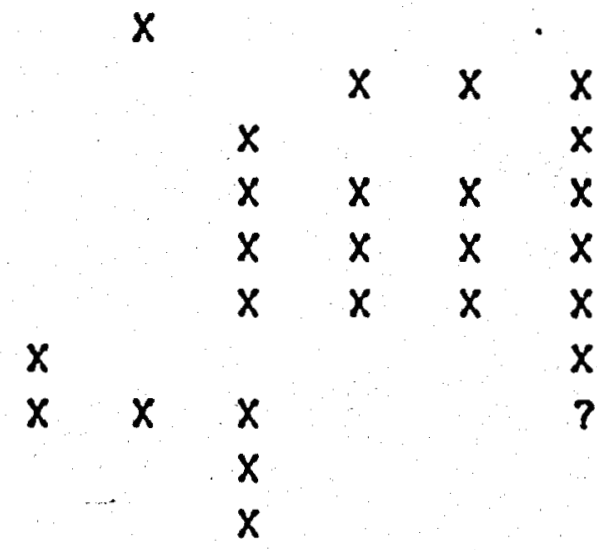

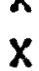

Table 1 
labeled "area" Indicate the realtive abundance of a porticular element within the area analyzed. However, these numbers connot be used to estimate a quantitative analysis of a specimen. Not also that the $X$-ray onoysis cannot detect the presence of elements lighter (i.e., with otomic numbers less) then magnesium. Thus, the carbon in the carbonote anolyses is not identified in the EDS print out. In oddition, $\mathrm{Cu}$ and Fe characteristic $X$-ray lines can be excited from the objective lens pole pieces of the SEM.

\section{RESULTS}

Ten specimens from vorious drill hole depths were exomined. Toble 1 presents a summary of the fracture and vesicle minerology of each sample.

2882 feet: Clear, elongate, vesicle filling crystols were identified as arogonite with XRD.

3412 feet: $X$-ray diffraction indicates the presence of two sulfides on the surface of fractures: marcasite and pyrite. Interpretation of the XRD pottern suggests that marcasite is predominant. Quolitative analysis presented in Toble 2A and s.e.i. confirms the presence of on Fe-sulfide (see s.e.i. photo 1). The presence of tridymite is also suggested by the XRD and EDS doto.

3470 feet: Greenish-brown "balls: on the surface of fractures were identified as siderite using XRD. Qualitative onalysis presented in Table 28 indicates that the phese is not pure (substitution of $\mathrm{Ca}$ and $\mathrm{Mn}$ for $\mathrm{Fe} 2+$ ). The botryoidal or "ball" form of siderite, characteristic of samples in this study, is shown in photo 2. Tridymite identified from the XRD pottern is olso shown in the s.e.i. phato.

3540 feet, 3580 feet, and 3705 feet: Materials scroped off the fracture surfaces of these three samples show similar X-ray diffraction patterns. . The presence of tridymite (milky white crystals), marcosite and pyrite (green material), and minor siderite is indicated. Quantitative analyses presented in Tables $2 \mathrm{C}$ and 20 confirm the presence of these minerals. The presence of minor omounts of o phyllosilicote (smectite or illite) is suggested by EDS results; however, this is not confirmed by XRO.

3770 feet: The white blocky crystals were identified as calcite and the green "balls" as siderite from the XRD pattern.

3948 feet: Three forms of minerals were examined indlvidually with XRD: 1) clear crystals, 2) milky white crystals, and 3) creom colored balls. The 
minerals were identiffed as: 1) aragonite, 2) colcite + orogonite, and 3) siderite. Siderite forms bal!s of webby textured crystols (phato 3), unlike the platy form from 3470 feet shown in photo 2 or columnor stscks which form the ocicular needles shown in the somple from 3970 feet.

3970 feet: The blue amygdule-lining material and balls were identified as magnesite with XRO. SEM qualitative analysis presented in Table $2 E$ confirms the presence of $\mathrm{Mg}$ and $\mathrm{Ca}$. The acicular green crystals radiating outward from amygdule walls were identified as siderite with XRO and confirmed with qualitative analysis presented in Toble $2 F$. Phato 4 is an s.e.i. picture of the relationship between these two phases.

3980 feet: The amygdule filling minerals in this sample ore the same os those at 3970 feet: magnesite and siderite. S.e.i. photo 5 shows siderite in balls of platy crystals and in the webby texture described at 3948 feet. 


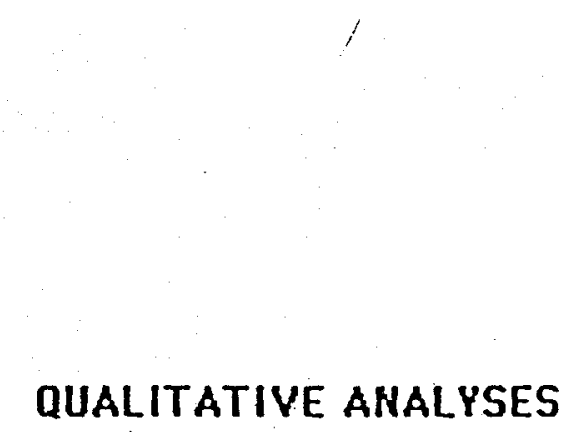

QUALITATIVE ANALYSES

C 

TABLE 2C: Fe-sulfide .

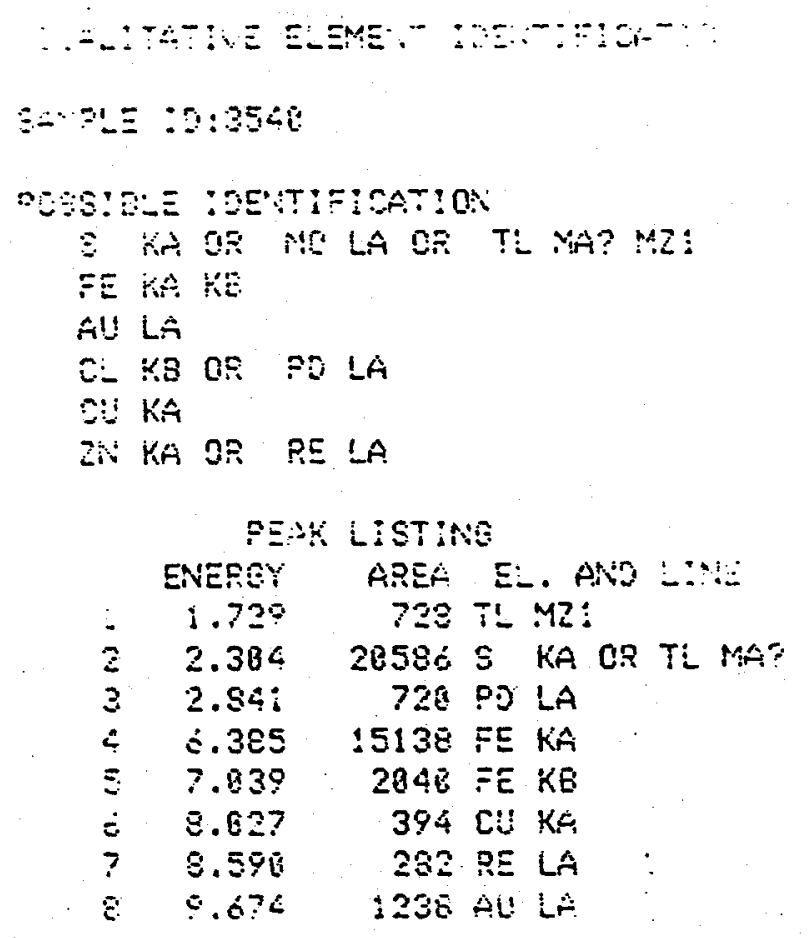


TABLE 2E: magnesite

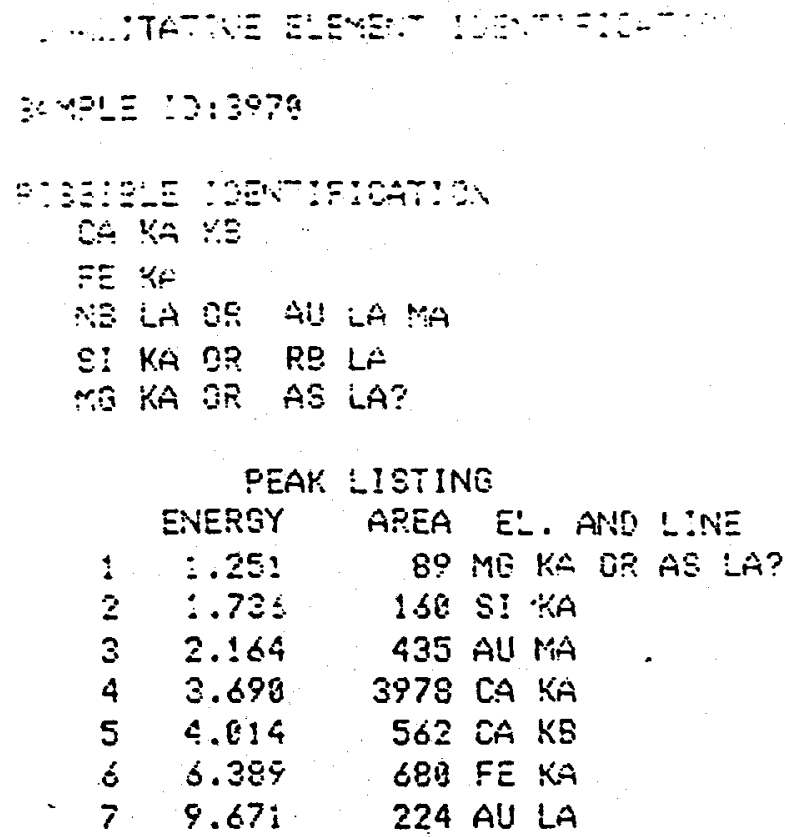

TABLE 2F: siderite

DUALITATIUE EIEMENT IOENTIF:GATIGH

SHPLE :0:3978

POSS:BLE IDENTIFICATION

$F \cong K A K E$

CA KA

S? KA OR RS LA

C: KA

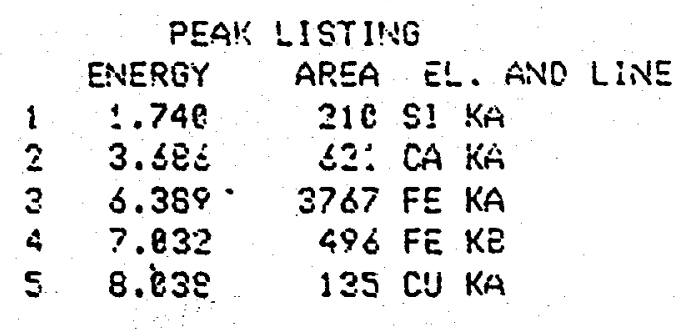




\section{FIGURE B2}

DRESSER ATLAS TEMPERATURE LOG OF 7-28-86 FOR GEO N-3, NEWBERRY VOLCANO, OREGON. This profile was constructed by GEO personnel from data taken from a continuous temperature log (see Table B2) which began 4 hours after last circulation of the core hole. Note the conductive slope for the last 100 plus feet. 
TABLE B2

GEO CORE HOLE $\mathrm{N}-3$

Temperature $\left(F^{\circ}\right)$ Log from Dresser At las of $7 / 28 / 86$

\begin{tabular}{|c|c|c|c|c|c|c|c|c|c|c|}
\hline Depth & 0 & 10 & 20 & 30 & 40 & 50 & 60 & 70 & 80 & 90 \\
\hline 0 & & & & & & 52 & 52 & 52 & 52 & 52 \\
\hline 100 & 52 & 52 & 52 & 52 & 52 & 51 & 51 & 51 & 51 & 51 \\
\hline \multicolumn{11}{|c|}{200 to $690=51^{\circ}$} \\
\hline 700 & 51 & 51 & 50 & 50 & 50 & 50 & 50 & 50 & 50 & 50 \\
\hline \multicolumn{11}{|c|}{800 to $1590=50^{\circ}$} \\
\hline 1600 & 50 & 50 & 51 & 52 & 53 & 53 & 53 & 53 & 54 & 53 \\
\hline 1700 & 53 & 53 & 53 & 53 & 53 & 53 & 53 & 53 & 53 & 54 \\
\hline 1800 & 54 & 54 & 54 & 54 & 54 & 55 & 55 & 55 & 55 & 55 \\
\hline 1900 & 55 & 56 & 56 & 57 & 57 & 58 & 58 & 62 & 76 & 98 \\
\hline 2000 & 101 & 103 & 104 & 105 & 106 & 106 & 106 & 107 & 107 & 107 \\
\hline 2100 & 107 & 107 & 107 & 107 & 108 & 108 & 108 & 108 & 108 & 109 \\
\hline 2200 & 109 & 109 & 109 & 109 & 109 & 109 & 110 & 110 & 110 & 110 \\
\hline 2300 & 110 & 110 & 110 & 111 & 111 & 111 & 111 & 111 & 111 & 111 \\
\hline 2400 & 112 & 112 & 112 & 112 & 112 & 112 & 113 & 113 & 113 & 113 \\
\hline 2500 & 113 & 113 & 113 & 113 & 113 & 114 & 114 & 114 & 114 & 114 \\
\hline 2600 & 114 & 114 & 114 & 115 & 115 & 115 & 115 & 115 & 115 & 115 \\
\hline 2700 & 115 & 115 & 115 & 115 & 116 & 116 & 116 & 116 & 116 & 116 \\
\hline 2800 & 116 & 116 & 116 & 117 & 117 & 117 & 117 & 117 & 117 & 117 \\
\hline 2900 & 117 & 117 & 117 & 117 & 117 & 117 & 117 & 117 & 118 & 118 \\
\hline 3000 & 118 & 118 & 218 & 118 & 118 & 118 & 118 & 118 & 119 & 119 \\
\hline 3100 & 119 & 119 & 119 & 119 & 119 & 119 & 119 & 119 & 119 & 119 \\
\hline 3200 & 119 & 119 & 119 & 119 & 119 & 119 & 120 & 120 & 120 & 120 \\
\hline 3300 & 120 & 120 & 120 & 120 & 120 & 120 & 120 & 120 & 120 & 120 \\
\hline 3400 & 120 & 121 & 121 & 121 & 121 & 121 & 121 & 121 & 121 & 121 \\
\hline
\end{tabular}

3500 to $3690=121^{\circ}$

$\begin{array}{lllllllllll}3700 & 121 & 121 & 121 & 121 & 121 & 121 & 121 & 122 & 122 & 122\end{array}$

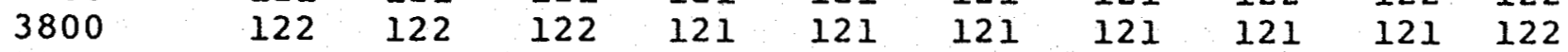

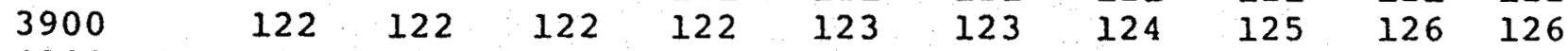

$4000 \quad 125$

$4002 \mathrm{BHT}=126^{\circ}$

Note: this table was compiled from an analog record and was rounded to the nearest degree.

Logging operations begin 4 hours after last circulation of core hole.

Spud date: $6 / 2 / 86$

Date TD reached: $7 / 29 / 86$ 
TABLE B2

GEO CORE HOLE $\mathrm{N}-3$

Temperature $\left(F^{\circ}\right)$ Log from Dresser At las of $7 / 28 / 86$

\begin{tabular}{|c|c|c|c|c|c|c|c|c|c|c|}
\hline Depth & 0 & 10 & 20 & 30 & 40 & 50 & 60 & 70 & 80 & 90 \\
\hline 0 & & & & & & 52 & 52 & 52 & 52 & 52 \\
\hline 100 & 52 & 52 & 52 & 52 & 52 & 51 & 51 & 51 & 51 & 51 \\
\hline \multicolumn{11}{|c|}{200 to $690=51^{\circ}$} \\
\hline 700 & 51 & 51 & 50 & 50 & 50 & 50 & 50 & 50 & 50 & 50 \\
\hline \multicolumn{11}{|c|}{800 to $1590=50^{\circ}$} \\
\hline 1600 & 50 & 50 & 51 & 52 & 53 & 53 & 53 & 53 & 54 & 53 \\
\hline 1700 & 53 & 53 & 53 & 53 & 53 & 53 & 53 & 53 & 53 & 54 \\
\hline 1800 & 54 & 54 & 54 & 54 & 54 & 55 & 55 & 55 & 55 & 55 \\
\hline 1900 & 55 & 56 & 56 & 57 & 57 & 58 & 58 & 62 & 76 & 98 \\
\hline 2000 & 101 & 103 & 104 & 105 & 106 & 106 & 106 & 107 & 107 & 107 \\
\hline 2100 & 107 & 107 & 107 & 107 & 108 & 108 & 108 & 108 & 108 & 109 \\
\hline 2200 & 109 & 109 & 109 & 109 & 109 & 109 & 110 & 110 & 110 & 110 \\
\hline 2300 & 110 & 110 & 110 & 111 & 111 & 111 & 111 & 111 & 111 & 111 \\
\hline 2400 & 112 & 112 & 112 & 112 & 112 & 112 & 113 & 113 & 113 & 113 \\
\hline 2500 & 113 & 113 & 113 & 113 & 113 & 114 & 114 & 114 & 114 & 114 \\
\hline 2600 & 114 & 114 & 114 & 115 & 115 & 115 & 115 & 115 & 115 & 115 \\
\hline 2700 & 115 & 115 & 115 & 115 & 116 & 116 & 116 & 116 & 116 & 116 \\
\hline 2800 & 116 & 116 & 116 & 117 & 117 & 117 & 117 & 117 & 117 & 117 \\
\hline 2900 & 117 & 117 & 117. & 117 & 117 & 117 & 117 & 117 & 118 & 118 \\
\hline 3000 & 118 & 118 & 118 & 118 & 118 & 118 & 118 & 118 & 119 & 119 \\
\hline 3100 & 119 & 119 & 119 & 119 & 119 & 119 & 119 & 119 & 119 & 119 \\
\hline 3200 & 119 & 119 & 119 & 119 & 119 & 119 & 120 & 120 & 120 & 120 \\
\hline 3300 & 120 & 120 & 120 & 120 & 120 & 120 & 120 & 120 & 120 & 120 \\
\hline 3400 & 120 & 121 & 121 & 121 & 121 & 121 & 121 & 121 & 121 & 121 \\
\hline \multicolumn{11}{|c|}{3500 to $3690=121^{\circ}$} \\
\hline 3700 & 121 & 121 & 121 & 121 & 121 & 121 & 121 & 122 & 122 & 122 \\
\hline 3800 & 122 & 122 & 122 & 121 & 121 & 121 & 121 & 121 & 121 & 122 \\
\hline 3900 & 122 & 122 & 122 & 122 & 123 & 123 & 124 & 125 & 126 & 126 \\
\hline 4000 & 125 & & & & & & & & & \\
\hline
\end{tabular}

$4002 \mathrm{BHT}=126^{\circ}$

Note: this table was compiled from an analog record and was rounded to the nearest degree.

Logging operations begin 4 hours after last circulation of core hole.

Spud date: $6 / 2 / 86$

Date TD reached: $7 / 29 / 86$ 
FIGURE B5

BLACKWELL TEMPERATURE LOG OF $9 / 26 / 86$ FOR CORE HOLE GEO $\mathrm{N}-3$. This profile was constructed by GEO personnel from selected data in Table B5. The precision and accuracy of the temperature measurements are $0.01^{\circ} \mathrm{F}$ and $1^{\circ} \mathrm{F}$. Temperatures were measured at 6.6 foot intervals. Note the conductive slope for the last 100 feet. 


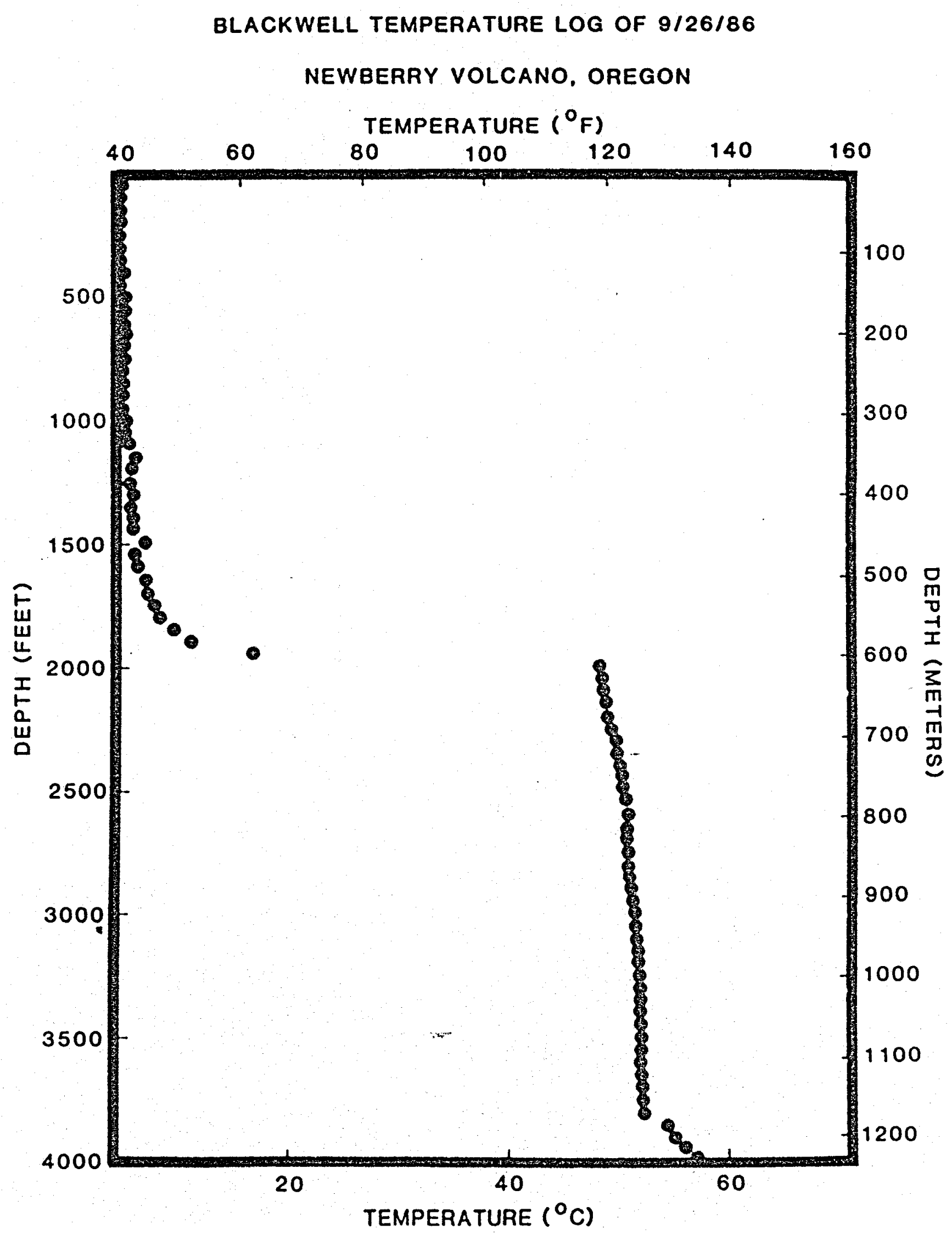


TABLE B5

GEO N-3

Temperature/Depth Data

Blackwe11: $9 / 26 / 86$

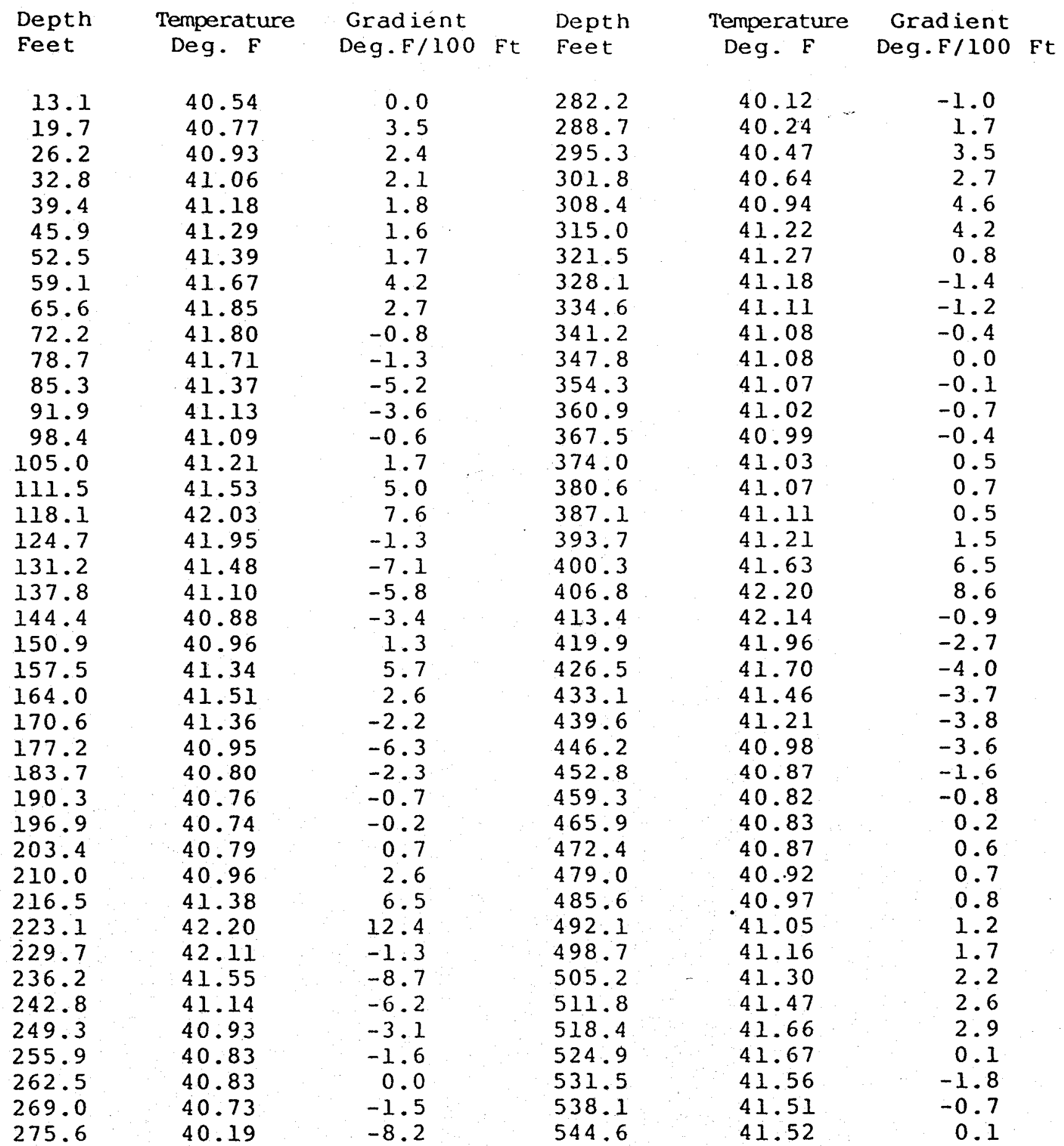


TABLE B5

GEO $\mathrm{N}-3$

Temperature/Depth Data

Blackwell: 9/26/86

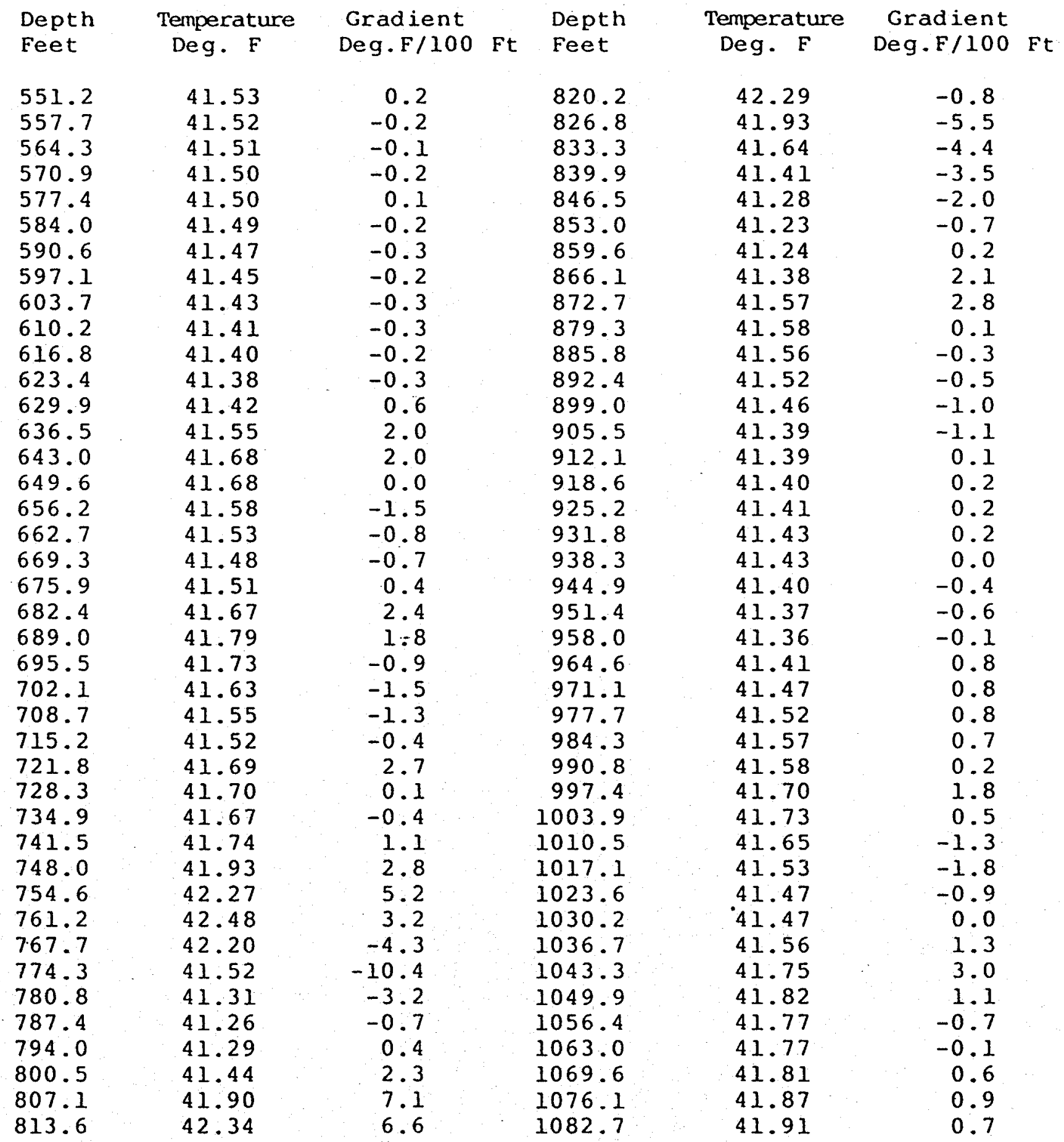


TABLE B5

GEO $\mathrm{N}-3$

Temperature/Depth Data

Blackwell: 9/26/86

\begin{tabular}{|c|c|c|c|c|c|c|}
\hline $\begin{array}{l}\text { Depth } \\
\text { Feet }\end{array}$ & $\begin{array}{l}\text { Temperature } \\
\text { Deg. F }\end{array}$ & $\begin{array}{l}\text { Gradient } \\
\text { Deg. } F / 100\end{array}$ & Ft & $\begin{array}{l}\text { Depth } \\
\text { Feet }\end{array}$ & $\begin{array}{l}\text { Temperature } \\
\text { Deg. F }\end{array}$ & $\begin{array}{r}\text { Gradient } \\
\text { Deg.F/100 }\end{array}$ \\
\hline 1089.2 & 41.97 & 0.8 & & 1358.3 & 42.40 & 1.6 \\
\hline 1095.8 & 42.06 & 1.4 & & 1364.8 & 42.51 & 1.6 \\
\hline 1102.4 & 42.10 & 0.6 & & 1371.4 & 42.59 & 1.3 \\
\hline 1108.9 & 42.09 & -0.2 & & 1378.0 & 42.65 & 0.8 \\
\hline 1115.5 & 42.32 & 3.5 & & 1384.5 & 42.71 & 0.9 \\
\hline 1122.0 & 42.88 & 8.6 & & 1391.1 & 42.80 & 1.4 \\
\hline 1128.6 & 43.34 & 6.9 & & 1397.6 & 42.92 & 1.8 \\
\hline 1135.2 & 43.31 & -0.3 & & 1404.2 & 43.06 & 2.2 \\
\hline 1141.7 & 43.20 & -1.8 & & 1410.8 & 43.17 & 1.6 \\
\hline 1148.3 & 43.03 & -2.5 & & 1417.3 & 43.20 & 0.5 \\
\hline 1154.9 & 42.54 & -7.6 & & 1423.9 & 43.17 & -0.5 \\
\hline 1161.4 & 42.14 & -6.1 & & 1430.4 & 43.10 & -1.1 \\
\hline 1168.0 & 41.99 & -2.3 & & 1437.0 & 43.00 & -1.5 \\
\hline 1174.5 & 42.02 & 0.5 & & 1443.6 & 42.90 & -1.5 \\
\hline 1181.1 & 42.31 & 4.4 & & 1450.1 & 42.79 & -1.6 \\
\hline 1187.7 & 42.60 & 4.5 & & 1456.7 & 42.73 & -0.9 \\
\hline 1194.2 & 42.67 & 1.0 & & 1463.3 & 42.73 & 0.0 \\
\hline 1200.8 & 42.54 & -2.0 & & 1469.8 & 42.81 & 1.3 \\
\hline 1207.3 & 42.39 & -2.3 & & 1476.4 & 42.98 & 2.6 \\
\hline 1213.9 & 42.27 & -1.7 & & 1482.9 & 43.21 & 3.4 \\
\hline 1220.5 & 42.27 & -0.1 & & 1489.5 & 43.51 & 4.7 \\
\hline 1227.0 & 42.25 & $-0 . \overline{3}$ & & 1496.1 & 43.90 & $5.9^{\circ}$ \\
\hline 1233.4 & 42.24 & -0.1 & & 1502.6 & 44.34 & 6.6 \\
\hline 1240.2 & 42.20 & -0.6 & & 1509.2 & 44.70 & 5.5 \\
\hline 1246.7 & 42.19 & -0.2 & & 1515.7 & 44.62 & -1.1 \\
\hline 1253.3 & 42.19 & 0.1 & & 1522.3 & 44.09 & -8.1 \\
\hline 1259.8 & 42.04 & -2.3 & & 1528.9 & 43.61 & -7.4 \\
\hline 1266.4 & 41.82 & -3.4 & & 1535.4 & 43.35 & -3.9 \\
\hline 1273.0 & 42.20 & 5.9 & & 1542.0 & 43.27 & -1.2 \\
\hline 1279.5 & 42.34 & 2.0 & & 1548.6 & 43.27 & 0.1 \\
\hline 1286.1 & 42.48 & 2.1 & & 1555.1 & 43.30 & 0.4 \\
\hline 1292.7 & 42.55 & 1.1 & & 1561.7 & 43.32 & 0.3 \\
\hline 1299.2 & 42.48 & -1.0 & & 1568.2 & 43.36 & 0.6 \\
\hline 1305.8 & 42.35 & -1.9 & & 1574.8 & 43.43 & 1.1 \\
\hline 1312.3 & 42.23 & -1.9 & & 1581.4 & 43.53 & 1.6 \\
\hline 1318.9 & 42.15 & -1.2 & & 1587.9 & 43.59 & 0.9 \\
\hline 1325.5 & 42.11 & -0.6 & & 1594.5 & 43.66 & 1.1 \\
\hline 1332.0 & 42.12 & 0.2 & & 1601.0 & 43.74 & 1.2 \\
\hline 1338.6 & 42.17 & 0.7 & & 1607.6 & 43.89 & 2.2 \\
\hline 1345.1 & 42.23 & 0.9 & & 1614.2 & 44.07 & 2.8 \\
\hline 1351.7 & 42.30 & 1.1 & & 1620.7 & 44.23 & 2.5 \\
\hline
\end{tabular}


TABLE B5

GEO $N-3$

Temperature/Depth Data

Blackwe 11: $9 / 26 / 86$

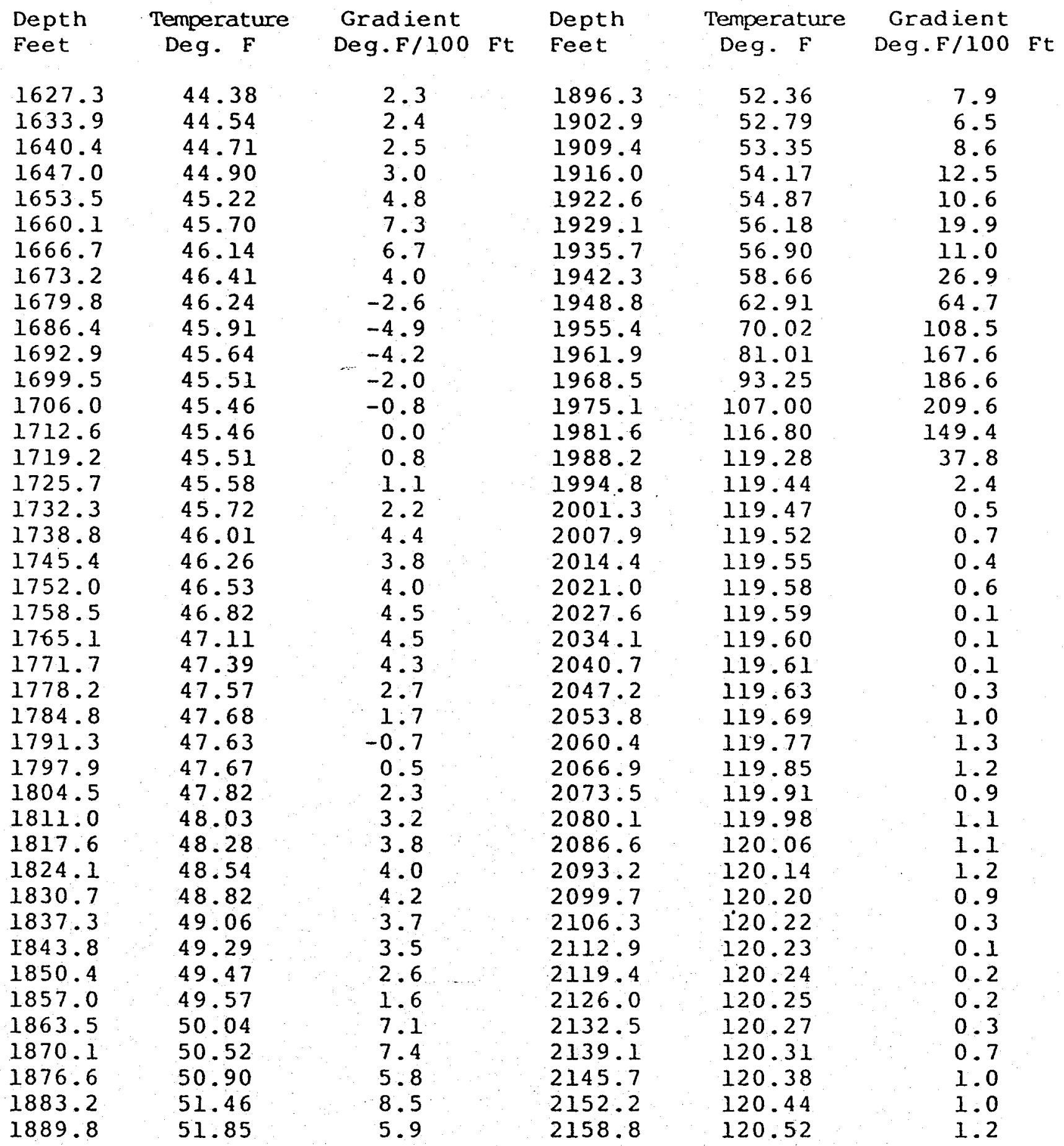


TABLE B5

GEO $\mathrm{N}-3$

Temperature/Depth Data

Blackwell: 9/26/86

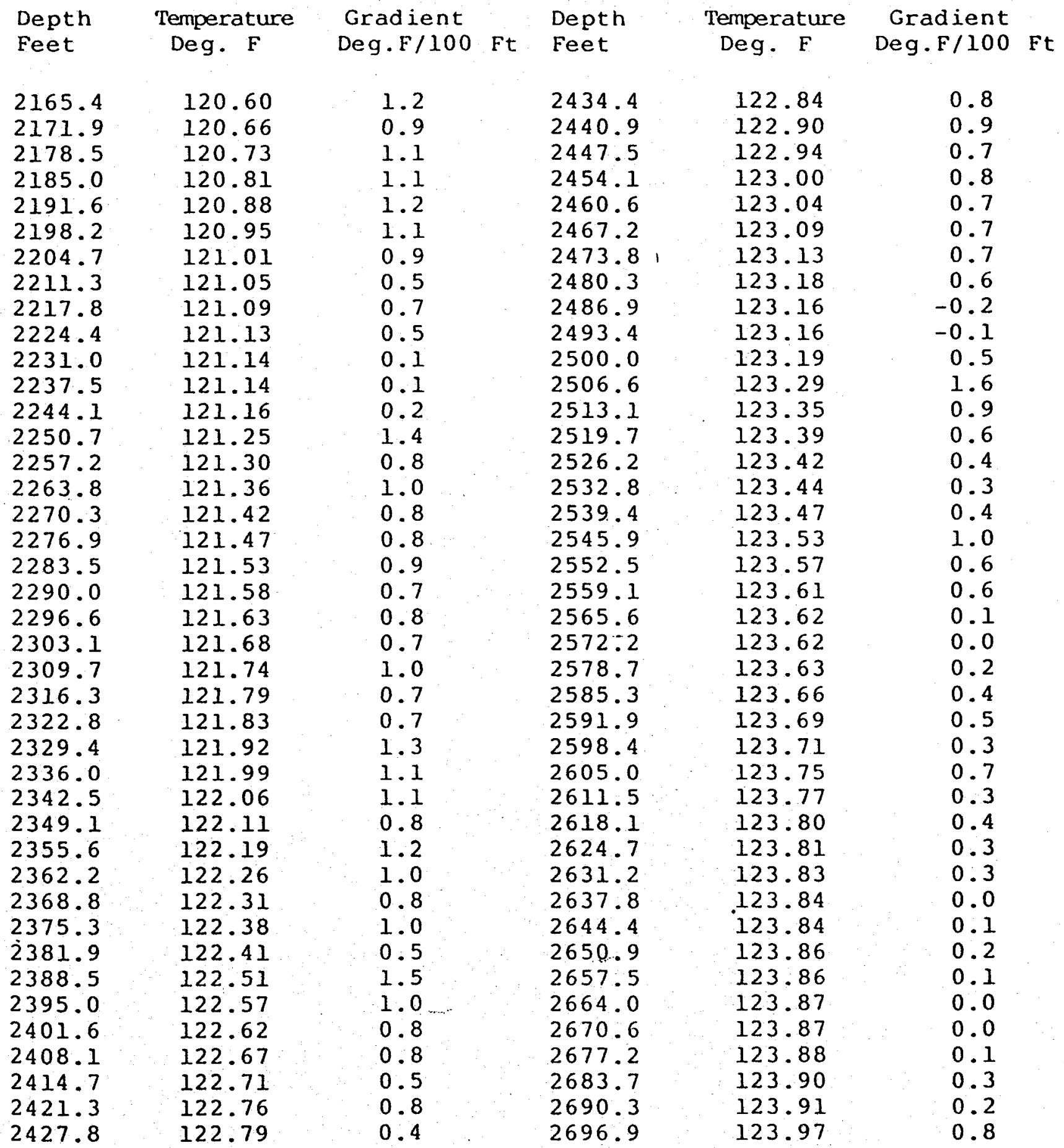


TABLE B5

GEO $\mathrm{N}-3$

Temperature/Depth Data

Blackwell: $9 / 26 / 86$

\begin{tabular}{|c|c|c|c|c|c|c|}
\hline $\begin{array}{l}\text { Depth } \\
\text { Feet }\end{array}$ & $\begin{array}{l}\text { Temperature } \\
\text { Deg. F }\end{array}$ & $\begin{array}{l}\text { Gradient } \\
\text { Deg.F/100 }\end{array}$ & $\mathrm{Ft}$ & $\begin{array}{l}\text { Depth } \\
\text { Feet }\end{array}$ & $\begin{array}{l}\text { Temperature } \\
\text { Deg. F }\end{array}$ & $\begin{array}{r}\text { Gradient } \\
\text { Deg.F/100 }\end{array}$ \\
\hline $\begin{array}{l}2703.4 \\
2710.0 \\
2716.5 \\
2723.1 \\
2729.7 \\
2736.2 \\
2742.8 \\
2749.3 \\
2755.9 \\
2762.5 \\
2769.0 \\
2775.6 \\
2782.2 \\
2788.7 \\
2795.3 \\
2801.8 \\
2808.4 \\
2815.0 \\
2821.5 \\
2828.1 \\
2834.6 \\
2841.2 \\
2847.8 \\
2854.3 \\
2860.9 \\
2867.5 \\
2874.0 \\
2880.6 \\
2887.1 \\
2893.7 \\
2900.3 \\
2906.8 \\
2913.4 \\
2919.9 \\
2926.5 \\
2933.1 \\
2939.6 \\
2946.2 \\
2952.8 \\
2959.3 \\
2965.9\end{array}$ & $\begin{array}{l}123.99 \\
124.01 \\
124.01 \\
124.01 \\
124.04 \\
124.05 \\
124.06 \\
124.06 \\
124.06 \\
124.06 \\
124.08 \\
124.11 \\
124.14 \\
124.17 \\
124.20 \\
124.23 \\
124.26 \\
124.29 \\
124.30 \\
124.26 \\
124.36 \\
124.40 \\
124.42 \\
124.45 \\
124.48 \\
124.51 \\
124.53 \\
124.57 \\
124.60 \\
124.63 \\
124.66 \\
124.67 \\
124.70 \\
124.72 \\
124.75 \\
124.77 \\
124.79 \\
124.82 \\
124.84 \\
124.87 \\
124.89\end{array}$ & 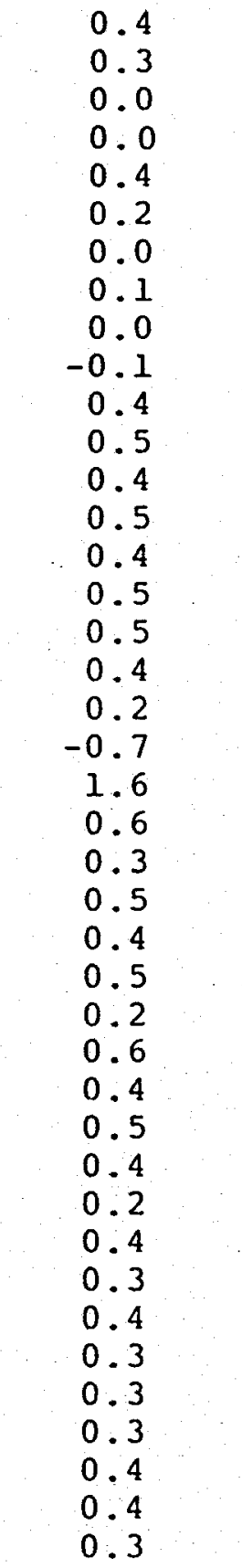 & & $\begin{array}{l}2972.4 \\
2979.0 \\
2985.6 \\
2992.1 \\
2998.7 \\
3005.2 \\
3011.8 \\
3018.4 \\
3024.9 \\
3031.5 \\
3038.1 \\
3044.6 \\
3051.2 \\
3057.7 \\
3064.3 \\
3070.9 \\
3077.4 \\
3084.0 \\
3090.6 \\
3097.1 \\
3103.7 \\
3110.2 \\
3116.8 \\
3123.4 \\
3129.9 \\
3136.5 \\
3143.0 \\
3149.6 \\
3156.2 \\
3162.7 \\
3169.3 \\
3175.9 \\
3182.4 \\
3189.0 \\
3195.5 \\
3202.1 \\
3208.7 \\
3215.2 \\
3221.8 \\
3228.3 \\
3234.9\end{array}$ & $\begin{array}{l}124.93 \\
124.95 \\
124.98 \\
125.00 \\
125.03 \\
125.06 \\
125.08 \\
125.09 \\
125.11 \\
125.14 \\
125.16 \\
125.19 \\
125.21 \\
125.24 \\
125.26 \\
125.28 \\
125.31 \\
125.33 \\
125.35 \\
125.37 \\
125.40 \\
125.42 \\
125.44 \\
125.45 \\
125.47 \\
125.49 \\
125.50 \\
125.52 \\
125.54 \\
125.54 \\
125.56 \\
125.56 \\
125.58 \\
125.59 \\
125.60 \\
125.62 \\
125.63 \\
125.64 \\
125.65 \\
125.67 \\
125.69\end{array}$ & $\begin{array}{l}0.5 \\
0.4 \\
0.4 \\
0.4 \\
0.5 \\
0.3 \\
0.3 \\
0.2 \\
0.3 \\
0.4 \\
0.4 \\
0.3 \\
0.4 \\
0.5 \\
0.2 \\
0.3 \\
0.6 \\
0.2 \\
0.4 \\
0.3 \\
0.4 \\
0.3 \\
0.3 \\
0.2 \\
0.3 \\
0.2 \\
0.2 \\
0.3 \\
0.3 \\
0.1 \\
0.2 \\
0.0 \\
0.2 \\
0.2 \\
0.2 \\
0.2 \\
0.2 \\
0.1 \\
0.2 \\
0.3 \\
0.3\end{array}$ \\
\hline
\end{tabular}


TABLE B5

GEO $\mathrm{N}-3$

Temperature/Depth Data

Blackweli: $9 / 26 / 86$

\begin{tabular}{|c|c|c|c|c|c|c|}
\hline $\begin{array}{l}\text { Depth } \\
\text { Feet }\end{array}$ & $\begin{array}{c}\text { Temperature } \\
\text { Deg. F }\end{array}$ & $\begin{array}{l}\text { Gradient } \\
\text { Deg. F/100 }\end{array}$ & $\mathrm{Ft}$ & $\begin{array}{l}\text { Depth } \\
\text { Feet }\end{array}$ & $\begin{array}{c}\text { Temperature } \\
\text { Deg. F }\end{array}$ & $\begin{array}{r}\text { Gradient } \\
\text { Deg.F/l00 }\end{array}$ \\
\hline $\begin{array}{l}3241.5 \\
3248.0 \\
3254.6 \\
3261.2 \\
3267.7 \\
3274.3 \\
3280.8 \\
3287.4 \\
3294.0 \\
3300.5 \\
3307.1 \\
3313.6 \\
3320.2 \\
3326.8 \\
3333.3 \\
3339.9 \\
3346.5 \\
3353.0 \\
3359.6 \\
3366.1 \\
3372.7 \\
3379.3 \\
3385.8 \\
3392.4 \\
3399.0 \\
3405.5 \\
3412.1 \\
3418.6 \\
3425.2 \\
3431.8 \\
3438.3 \\
3444.9 \\
3451.4 \\
3458.0 \\
3464.6 \\
3471.1 \\
3477.7 \\
3484.3 \\
3490.8 \\
3494.4 \\
3503.9\end{array}$ & $\begin{array}{l}125.69 \\
125.67 \\
125.73 \\
125.75 \\
125.76 \\
125.78 \\
125.78 \\
125.80 \\
125.82 \\
125.83 \\
125.84 \\
125.82 \\
125.88 \\
125.89 \\
125.90 \\
125.90 \\
125.88 \\
125.93 \\
125.94 \\
125.95 \\
125.96 \\
125.97 \\
125.98 \\
125.98 \\
125.99 \\
126.00 \\
126.01 \\
126.02 \\
126.03 \\
126.03 \\
126.04 \\
126.05 \\
126.05 \\
126.07 \\
126.06 \\
126.09 \\
126.09 \\
126.10 \\
126.11 \\
126.11 \\
126.13\end{array}$ & $\begin{array}{r}0.1 \\
-0.3 \\
0.8 \\
0.3 \\
0.2 \\
0.3 \\
0.1 \\
0.2 \\
0.3 \\
0.2 \\
0.1 \\
-0.2 \\
0.8 \\
0.2 \\
0.1 \\
0.0 \\
-0.3 \\
0.8 \\
0.1 \\
0.2 \\
0.1 \\
0.1 \\
0.2 \\
0.0 \\
0.2 \\
0.1 \\
0.1 \\
0.2 \\
0.1 \\
0.1 \\
0.1 \\
0.2 \\
0.1 \\
0.2 \\
-0.1 \\
0.4 \\
0.1 \\
0.1 \\
0.1 \\
0.1 \\
0.2\end{array}$ & & $\begin{array}{l}3510.5 \\
3517.1 \\
3523.6 \\
3530.2 \\
3536.7 \\
3543.3 \\
3549.9 \\
3556.4 \\
3563.0 \\
3569.6 \\
3576.1 \\
3582.7 \\
3589.2 \\
3595.8 \\
3602.4 \\
3608.9 \\
3615.5 \\
3622.0 \\
3628.6 \\
3635.2 \\
3641.7 \\
3648.3 \\
3654.9 \\
3661.4 \\
3668.0 \\
3674.5 \\
3681.1 \\
3687.7 \\
3694.2 \\
3700.8 \\
3707.3 \\
3713.9 \\
3720.5 \\
.3727 .0 \\
3733.6 \\
3740.2 \\
3746.7 \\
3753.3 \\
3759.8 \\
3766.4 \\
3773.0\end{array}$ & $\begin{array}{l}126.13 \\
126.13 \\
126.14 \\
126.14 \\
126.15 \\
126.15 \\
126.16 \\
126.16 \\
126.15 \\
126.19 \\
126.20 \\
126.20 \\
126.18 \\
126.20 \\
126.21 \\
126.22 \\
126.20 \\
126.23 \\
126.24 \\
126.25 \\
126.25 \\
126.24 \\
126.25 \\
126.27 \\
126.28 \\
126.28 \\
126.27 \\
126.29 \\
126.30 \\
126.31 \\
126.31 \\
126.30 \\
126.32 \\
126.32 \\
126.33 \\
126.32 \\
126.33 \\
126.35 \\
126.34 \\
126.36 \\
126.37\end{array}$ & $\begin{array}{r}0.0 \\
0.0 \\
0.2 \\
0.0 \\
0.1 \\
0.0 \\
0.1 \\
0.0 \\
-0.2 \\
0.0 \\
0.1 \\
0.0 \\
-0.2 \\
0.4 \\
0.1 \\
0.1 \\
-0.3 \\
0.4 \\
0.1 \\
0.1 \\
0.0 \\
-0.1 \\
0.2 \\
0.3 \\
0.1 \\
0.1 \\
-0.1 \\
0.3 \\
0.2 \\
0.1 \\
0.0 \\
-0.1 \\
0.4 \\
0.1 \\
0.0 \\
-0.1 \\
0.2 \\
0.2 \\
0.0 \\
0.2 \\
0.1\end{array}$ \\
\hline
\end{tabular}




\section{TABLE B5 \\ GEO $\mathrm{N}-3$ \\ Temperature/Depth Data \\ Blackwell: 9/26/86}

\begin{tabular}{|c|c|c|c|c|c|c|}
\hline $\begin{array}{l}\text { Depth } \\
\text { Feet }\end{array}$ & $\begin{array}{c}\text { Temperature } \\
\text { Deg. F }\end{array}$ & $\begin{array}{l}\text { Gradient } \\
\text { Deg.F/100 }\end{array}$ & $\mathrm{Ft}$ & $\begin{array}{l}\text { Depth } \\
\text { Feet }\end{array}$ & $\begin{array}{c}\text { Temperature } \\
\text { Deg. F }\end{array}$ & $\begin{array}{r}\text { Gradient } \\
\text { Deg.F/l00 }\end{array}$ \\
\hline $\begin{array}{l}3779.5 \\
3786.1 \\
3792.7 \\
3799.2 \\
3805.8 \\
3812.3 \\
3818.9 \\
3825.5 \\
3832.0 \\
3838.6 \\
3845.1 \\
3851.7 \\
3858.3 \\
3864.8 \\
3871.4 \\
3878.0 \\
3884.5 \\
3891.1\end{array}$ & $\begin{array}{l}126.43 \\
126.43 \\
126.44 \\
126.44 \\
126.43 \\
126.45 \\
126.55 \\
126.75 \\
126.71 \\
128.58 \\
130.16 \\
130.46 \\
130.71 \\
130.71 \\
130.77 \\
130.96 \\
131.07 \\
131.27\end{array}$ & $\begin{array}{r}1.0 \\
0.0 \\
0.2 \\
0.0 \\
-0.2 \\
0.4 \\
1.5 \\
3.1 \\
-0.7 \\
28.5 \\
24.2 \\
4.6 \\
3.7 \\
0.0 \\
1.0 \\
2.9 \\
1.7 \\
3.0\end{array}$ & & $\begin{array}{l}3897.6 \\
3904.2 \\
3910.8 \\
3917.3 \\
3923.9 \\
3930.4 \\
3937.0 \\
3943.6 \\
3950.1 \\
3956.7 \\
3963.3 \\
3969.8 \\
3976.4 \\
3982.9 \\
3989.5 \\
3996.1 \\
4002.6\end{array}$ & $\begin{array}{l}131.34 \\
131.36 \\
131.52 \\
132.47 \\
132.49 \\
132.69 \\
132.92 \\
133.10 \\
133.34 \\
133.47 \\
133.63 \\
133.71 \\
133.90 \\
134.09 \\
134.25 \\
134.64 \\
134.76\end{array}$ & $\begin{array}{r}1.1 \\
0.3 \\
2.5 \\
14.5 \\
0.4 \\
3.0 \\
3.5 \\
2.7 \\
3.7 \\
2.1 \\
2.3 \\
1.3 \\
2.8 \\
2.9 \\
2.4 \\
6.1 \\
1.7\end{array}$ \\
\hline
\end{tabular}


Half-splits of core from GEO N-3 of 0-4000 feet were provided to the University of Utah Research Institute (UURI) personnel on August 20, 1986 in Bend, Oregon. 